\title{
Community Banks and Rural Development: Research Relating to Proposals to Revise the Regulations That Implement the Community Reinvestment Act
}

Robert B. Avery, Glenn B. Canner, and Shannon C. Mok, of the Division of Research and Statistics, and Dan S. Sokolov, of the Division of Consumer and Community Affairs, prepared this article. Onka $L$. Tenkean provided research assistance.

Since 1977, the Community Reinvestment Act (CRA) has required that federally insured banking institutions-commercial banks and savings associations - be evaluated on their records of helping to meet the credit needs of their local communities, including low- and moderate-income (hereafter, lower-income) neighborhoods. In 1995, the four federal agencies responsible for bank supervision substantially revised the regulations that implement the CRA.' The revisions were intended to emphasize performance rather than process, to reduce unnecessary regulatory burden, and to increase consistency in CRA evaluations.

Under the 1995 regulations, "large" institutions, generally those with assets of $\$ 250$ million or more, have been evaluated under a three-part test, whereas "small" institutions, generally those with assets of less than $\$ 250$ million, have been subject to comparatively streamlined evaluations. Large institutions have been required to report data annually on certain types of CRA-related loans (small-business, smallfarm, and community development loans) and on the geographic areas (for example, census tracts) that constitute their local communities, whereas small institutions have been exempt from such reporting.

In 2001, the agencies began reviewing the CRA regulations to determine whether they were successful in meeting the objectives that the agencies set forth in 1995. The review focused in part on the possibility of extending the eligibility for streamlined examinations and the exemption from data reporting

1. The agencies are the Board of Governors of the Federal Reserve System (Board), the Federal Deposit Insurance Corporation (FDIC), the Office of the Comptroller of the Currency (OCC), and the Office of Thrift Supervision (OTS). to more institutions. In 2004 and 2005, the agencies put forth several proposals to implement these changes by raising the asset-size threshold from $\$ 250$ million to $\$ 500$ million or $\$ 1$ billion. The proposals, and the public's comments on them, paid particular attention to how and when to evaluate the community development performance of banking institutions with assets of less than $\$ 1$ billion, especially in rural areas, where such institutions have a proportionately larger presence than in urban areas. A related but separate issue that the agencies presented for public comment was how to define which bank activities in rural areas should be considered community development in CRA evaluations.

We have evaluated a large amount of data to gain insight into the potential effects of these proposals, and in this article we report the key findings of our research. Our intent is to inform deliberation over the recent proposals, not to advocate any particular view.

\section{BRIEF DESCRIPTION OF THE CRA}

The CRA encourages federally insured banking institutions to help meet the credit needs of their communities, including lower-income neighborhoods, in a way that is consistent with the safe and sound operation of those institutions. ${ }^{2}$ In particular, the CRA directs the federal agencies responsible for bank supervision (1) to assess through examinations every institution's record of meeting such community credit needs and (2) to consider the institution's CRA record when evaluating its application for deposit insurance or for a charter, branch or other deposit facility, office relocation, or merger or acquisition.

The CRA gives the agencies broad discretion to implement the law. For example, the act does not

2. For a more expansive overview of the history of the CRA, see Griffith L. Garwood and Dolores S. Smith (1993), "The Community Reinvestment Act: Evolution and Current Issues," Federal Reserve Bulletin, vol. 79 (April), pp. 251-67. 
define "low- or moderate-income neighborhood" or a banking institution's "community"; rather, the act leaves those definitions to the agencies. The act also leaves to the agencies the establishment of criteria for rating an institution's record of meeting its community's credit needs. Each agency has separate rulewriting authority for the institutions it supervises; but with one recent exception, the four agencies have adopted identical regulations. ${ }^{3}$

The 1995 regulations establish objective standards for measuring performance. Rather than providing specific lending thresholds for particular CRA ratings, however, the standards are flexible and are applied in the context of information about an institution, its community, and its competitors (broadly referred to as the institution's "performance context"). Moreover, the standards relate not only to the quantity of an institution's activities (for example, the dollar amount of mortgage loans extended) but also to the quality of those activities (that is, their correlation with the community's needs for credit).

Examiners evaluate institutions primarily on their performance in their local communities, which the regulations define as the institutions' "assessment areas." Assessment areas encircle an institution's deposit-taking facilities, such as its branches and, if applicable, its automated teller machines (ATMs). Assessment areas are composed of census tracts or aggregations of census tracts, such as counties or metropolitan statistical areas. Examiners consider an institution's performance outside its assessment area only in limited circumstances.

Transparency is an important aspect of the regulations. Every institution's CRA rating - either "outstanding," "satisfactory," "needs to improve," or "substantial noncompliance" — is made public, as is a written evaluation that explains the basis of the rating. 4 Moreover, large banking instilutions musl reporl loan data to their supervisory agencies, which make the data publicly available. Large institutions must report the number and dollar amount of their

3. Office of the Comptroller of the Currency, Board of Governors of the Federal Reserve System, Federal Deposit Insurance Corporation, Office of Thrift Supervision (1995), "Community Reinvestment Act Regulations," Federal Register, vol. 60 (May 4), pp. 22156, 22178

4. CRA ratings, the type of evaluation (for example, smallinstitution or large-institution), the date of the evaluation, and the name of the agency that conducted the evaluation are available from the Federal Financial Institutions Examination Council (FFIEC) at www.ffiec.gov. Comprehensive written evaluations, including "subratings," are available through links from the FFIEC's website to the websites of the supervisory agencies, which post the evaluations as PDF files. The sub-ratings are available in written form only; they are unavailable in a quantitative, easy-to-use format that would facilitate analysis. small-business and small-farm loans by individual census tract. They must also report the total number and dollar amount, but not the geographic distribution, of their community development loans. In addition, if an institution is subject to the reporting requirements of the Home Mortgage Disclosure Act (HMDA), it is required to disclose detailed information about its mortgage loans; if the institution is also large for CRA purposes, it must report geographic information for rural mortgage loans, which it otherwise does not need to report..$^{5}$

The criteria in the 1995 regulations for evaluating an institution's performance incorporate four key distinctions. First, the criteria distinguish large banking institutions from small ones. Large banking institutions are subject to a three-part test that looks at lending, investments, and services, whereas small banking institutions face a streamlined test that concentrates on lending (see boxes "The LargeInstitution Evaluation" and "The Small-Institution Evaluation"). Moreover, large banking institutions must report data to the agencies; small banking institutions need not do so.

Second, the criteria distinguish among types of banking activity: lending, investing, and providing services. The regulations require the agencies to give large banking institutions explicit sub-ratings on each of these types of activity. Although small banking institutions are not usually evaluated on their investments or services, they may improve their chances of receiving an "outstanding" CRA rating if they elect to be evaluated in those areas.

Third, the evaluation criteria reflect a distinction between area-based and recipient-based measures of performance. The CRA's measure of area is the census tract. Key area-based criteria in CRA evaluations include the proportion of an institution's retail loans, and the proportion of its branches, in lower-income census tracts. Categories of census tract income are determined by the ratio of a census tract's median family income to the median family income of the relevant surrounding area as established at the most recent decennial census. The ranges are 0-49 percent (low), 50-79 percent (moderate), 80-119 percent (middle), and 120 percent or more (upper). For a census tract in a metropolitan (urban) area, the relevant surrounding area is the metropoli-

5. Institutions that are large under the CRA and are covered by HMDA must report the census tracts of all properties for which loans have been extended or for which loan applications have been received unless the loan is made or the application is received in a county with a population of 30,000 or less, in which case reporting the census tract is optional. Small institutions covered by HMDA may, but need not, report the property locations (census tracts and counties) for their rural loans. 


\section{The Large-Institution Evaluation}

The regulations that implement the CRA establish three tests by which the performance of most large retail banking institutions is evaluated: a lending test, an investment test, and a service test.

The lending test measures lending activity for many types of loan, including home mortgage, small-business, and small-farm loans. The assessment criteria are the proportion of an institution's loans in its assessment areas, the distribution of lending across borrowers of different incomes, the distribution of lending across census tracts of different incomes, the extent of community development lending, and the use of innovative or flexible lending practices to address the credit needs of lower-income individuals or areas.

The investment test considers a banking institution's qualified investments that benefit its assessment area or a broader statewide or regional area that includes its assessment area. A qualified investment is a lawful investment, deposit, membership share, or grant that has community development as its primary purpose.

The service test considers the availability of an institution's system for delivering retail banking services and judges the extent of its community development services and their innovativeness and responsiveness. Among the assessment criteria for retail banking services are the geographic distribution of an institution's branches and the availability and effectiveness of alternative systems for delivering retail banking services, such as automated teller machines, in lower-income areas and to lowerincome persons.

tan area. For a census tract in a nonmetropolitan (rural) area, the relevant surrounding area is the entire nonmetropolitan region of the state. Baseline classifications of census tract income change every ten years with the release of the census. ${ }^{6}$

In addition to area-based measures of performance, CRA evaluations use analogous recipient-based measures. Examples include the proportion of an institution's loans extended to lower-income borrowers (in the case of mortgage and consumer loans) and to enterprises of different sizes (in the case of smallbusiness and small-farm loans) and the proportion of an institution's services offered to lower-income individuals. The evaluation criteria classify borrowers by income in relation to the median family income of the relevant surrounding area. In doing so, the criteria use the same percentage breakdowns used to classify census tracts by income and the same metropolitannonmetropolitan distinction to construct the baseline.

6. Some tract classifications adjust more frequently than once a decade because of changes in the boundaries of metropolitan areas.

\section{The Small-Institution Evaluation}

Small institutions are eligible for streamlined CRA evaluations and are exempt from CRA data reporting obligations. The performance of a small institution is measured by its efforts to help meet the credit needs of its assessment area. These efforts are evaluated according to the following criteria:

- the institution's overall ratio of loan dollars to deposits

- the percentage of loans or, as appropriate, other lending-related activities in the assessment area

- the institution's record of lending to borrowers of different income levels and to businesses and farms of different sizes

- the geographic distribution of the institution's loans

- the institution's record of responding to written complaints about its performance in helping to meet credit needs in assessment areas

The main difference between the classifications for borrowers and those for census tracts is that baseline classifications for borrowers are updated every year, when the Department of Housing and Urban Development publishes the estimates of area family income, whereas those for census tracts are updated every ten years.

Fourth, the evaluation criteria distinguish between retail activities, which are often regarded as the traditional business of a banking institution, and community development activities, which are intended primarily to improve the welfare of lower-income people or areas. The regulation recognizes four categories of community development activity, three of which (affordable housing, community services, and economic development through small-business or small-farm financing) target certain recipientslower-income people, small businesses, or small farms - and one of which (revitalization and stabilization) targets certain areas-lower-income census tracts. For a large institution, community development performance is a factor in the CRA sub-rating on each of the three activity-based tests (lending, investment, and service). In the case of the investment test, the sub-rating depends entirely on the institution's record of making community development investments, whereas in the case of the lending and service tests, the sub-rating depends, respectively, on the institution's record of providing retail and community development loans and on its record of providing retail and community development services.

For a small institution, unlike for a large one, community development performance is not a man- 
datory part of the evaluation. But a small institution may choose to be evaluated on its community development loans, investments, or services as a basis for possibly boosting the institution's rating from "satisfactory" to "outstanding."

\section{THE 'AGENCIES' PROPOSALS TO 'AMEND THE CRA REGULATIONS}

In 1995, when the four banking agencies adopted major amendments to the regulations that implement the CRA, they committed themselves to reviewing the amended regulations to assess the regulations' effectiveness in emphasizing performance over process, promoting consistency in evaluations, and eliminating unnecessary regulatory burden. ${ }^{7}$ They began that review in July 2001 with the publication in the Federal Register of an advance notice of pro-

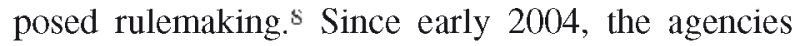
have issued several proposals.

\section{'Recent CRA Proposals}

In February 2004, the banking agencies issued identical proposals to amend their respective CRA regulations to increase the number of institutions classified as small. ${ }^{9}$ Under the 1995 regulations, an institution is defined as small if it has less than $\$ 250$ million in assets and is not a member of a holding company that has $\$ 1$ billion or more in assets. Institutions not defined as small are classified as large. ${ }^{10}$ The four agencies proposed to expand the definition of "small institution" to cover those institutions with assets of up to $\$ 500$ million and to eliminate the holding company criterion.

Commenters on that proposal were deeply split. Industry commenters, seeking to reduce their regulatory burden, wanted to raise the large-institution threshold higher than was proposed (as high as $\$ 2$ billion). But community groups opposed any increase

7. OCC, Board, FDIC, OTS (1995), "Community Reinvestment Act Regulations," pp. 22156, 22178.

8. Office of the Comptroller of the Currency, Board of Governors of the Federal Reserve System, Federal Deposit Insurance Corporation, Office of Thrift Supervision (2001), "Community Reinvestment Act Regulations," advance notice of proposed rulemaking, Federal Register, vol. 66 (July 19), p. 37602.

9. Office of the Comptroller of the Currency, Board of Governors of the Federal Reserve System, Federal Deposit Insurance Corporation, Office of Thrift Supervision (2004), "Community Reinvestment Act Regulations," Federal Register, vol. 69 (Feb. 6), p. 5729.

10. To be considered large, an institution must fail to meet the criteria for a small institution as of December 31 of both of the previous two calendar years. in the threshold, asserting that an increase would lead institutions newly classified as small to reduce their investments in community development.

In July 2004, the OTS announced that it would raise the large-institution threshold for savings associations to $\$ 1$ billion, the OCC announced that it would refrain from adopting the February proposal, and the Board stated that it would formally withdraw the proposal from consideration. ${ }^{11}$ The Board explained that raising the large-institution threshold to $\$ 500$ million was not guaranteed to yield significant cost savings for institutions and that it might significantly reduce investments in community development in some rural communities. ${ }^{12}$

A month later, the FDIC issued a new proposal to raise the large-institution threshold to $\$ 1$ billion for FDIC-supervised institutions and to continue to evaluate institutions with assets between $\$ 250$ million and $\$ 1$ billion on their community development records but on a modified basis. ${ }^{13}$ Again, commenters were divided over the proposal. Many industry commenters opposed evaluating these institutions on their community development records; many community group commenters contended that the proposed evaluation was not rigorous.

Also in August 2004, the FDIC proposed that a bank activity that benefits an individual or a community in a rural area be considered community development under the CRA, even if neither the individual nor the community is of lower income. Commenters also split on that proposal. Some expressed concern that the agency would give CRA recognition to bank investments in affluent rural areas. Some supported the proposal, however, because they favored recognizing institutions' support of infrastructure, business development, and other needs in rural areas as community development.

In November 2004, the OTS, too, proposed to recognize as community development a bank activity that benefits an individual or a community in a rural area, even if neither the individual nor the community is of lower income..$^{14}$

\footnotetext{
11. The OTS implemented its increase in a final rule published on August 18, 2004. See Office of Thrift Supervision (2004), "Community Reinvestment Act Regulations," Federal Register, vol. 69 (Aug. 18), p. 51155.

12. See Board of Governors of the Federal Reserve System (2004), press release, July 16 , www.federalreserve.gov/boarddocs/press/all/ 2004.

13. Federal Deposit Insurance Corporation (2004), "Community Reinvestment Act Regulations," Federal Register, vol. 69 (Aug. 20), p. 51611.

14. Office of Thrift Supervision (2004), "Community Reinvestment Act—Community Development, Assigned Ratings," Federal Register, vol. 69 (Nov. 24), p. 68257.
} 


\section{The Three-Agency Proposal of February 2005}

In February 2005, the Board, the OCC, and the FDIC published for public comment a joint proposal, which again addressed the definitions of "small institution" and "community development" in rural areas. The proposal would modify the CRA regulations in three ways:

1. It would raise the asset threshold for a large institution from $\$ 250$ million to $\$ 1$ billion and would eliminate the holding company criterion. Thus, all banking institutions with less than $\$ 1$ billion in assets would be exempt from CRA data reporting obligations.

2. It would create a subcategory of small institutions called "intermediate small institutions," those with assets between $\$ 250$ million and $\$ 1$ billion, and would subject such institutions to a two-part evaluation. ${ }^{15}$

- One part would evaluate the institution's retail lending. The evaluation would use the criteria now used for small institutions (those with less than $\$ 250$ million in assets)-for example, the ratio of overall loan dollars to deposits and the distribution of loans across borrowers and areas of different relative incomes. Those criteria differ little in substance from the criteria applied to the retail lending of large institutions, but the evaluation of small institutions' retail lending is, in practice, more streamlined because of their exemption from the requirement to collect or report data on loans and assessment areas.

- A second part, given equal weight in assigning an overall CRA rating, would evaluate an intermediate small institution's community development record. Instead of considering that record in three separate tests (as does the largeinstitution evaluation, which now applies to intermediate small institutions), the evaluation would gather into one test all community development activities, regardless of type, including lending, investing, and providing services.

3. It would revise the definition of "community development" in rural areas-for institutions of

15. The proposal would leave unchanged the criteria for evaluating small institutions (those with less than $\$ 250$ million in assets); as noted earlier, these criteria concentrate on retail lending (see box "The Small-Institution Evaluation"). The proposal would also leave unchanged the criteria for evaluating large institutions (those with more than $\$ 1$ billion in assets), which would continue to be subject to a three-part evaluation (see box "The Large-Institution Evaluation"). any size. The definition in the 1995 regulations imposes a lower-income restriction on bank activities that may be credited as community development in CRA evaluations: Such activities must primarily benefit either lower-income people or lower-income areas. The agencies proposed to relax that restriction in rural areas.

- Under the proposal, bank activities would be considered community development if they revitalized or stabilized any "underserved rural area" or provided affordable housing for any individual in any such area, even if the area was not defined as "low or moderate income." The agencies sought comment on how to identify underserved rural areas not already classified as lower-income tracts. The agencies specifically sought comment on criteria adapted from the Community Development Financial Institutions Fund's definition of an "investment area." The criteria, as adapted, would identify as underserved an area that has at least one of the following characteristics: (1) an unemployment rate of at least 1.5 times the national average, (2) a poverty rate of 20 percent or more, or (3) a population loss of 10 percent or more between the previous and most recent decennial censuses or a net migration loss of 5 percent or more over the five-year period preceding the most recent census.

- The agencies also sought comment on an alternative proposal to liberalize the definition of a "low or moderate income" rural census tract in one of two ways, at least for the purpose of determining which area-based activities in rural areas are considered community development: (1) change the baseline for defining rural tract incomes from the nonmetropolitan state median income to the statewide median income, which is the higher of the two statistics in all but one state, or (2) raise the "low or moderate income" limit from its current level of 80 percent.

\section{EFFECTS OF RAISING THE ASSET-SIZE THKESHOLD}

As noted earlier, the 2005 proposal would raise the asset-size threshold for a large institution from $\$ 250$ million to $\$ 1$ billion and would eliminate the holding company criterion. Institutions with asset sizes below the $\$ 1$ billion threshold would be subject to a streamlined CRA lending test equivalent to that now used for small institutions; they would also be 
exempt from the evaluation of branching under the service test now applied to institutions with assets of more than $\$ 250$ million. ${ }^{16}$ The proposal would also create a new community development test for intermediate small institutions.

In the first part of this section, we analyze several issues related to this portion of the proposal. ${ }^{17}$ First, we identify and describe the institutions and banking markets that would be affected by raising the threshold to $\$ 1$ billion and eliminating the holding company criterion. Second, we examine the potential effect of using a streamlined version of the CRA lending test and eliminating the service (branching) test for institutions with asset sizes below the threshold. Specifically, we examine the effect of the current $\$ 250$ million threshold on the retail lending and branching activities of institutions within a narrow range of the current threshold. Third, we consider whether the role of community development lending in CRA ratings has been significant.

\section{Parties Affected by Raising the Threshold and Eliminating the Holding Company Criterion}

Raising the threshold and eliminating the holding company criterion would affect both banking institutions and the communities they serve. Using 2003 as a test year, we looked at the characteristics of institutions that would have been subject to a different CRA evaluation process had the regulations proposed in February 2005 been in effect. ${ }^{18}$ We also identified the local banking markets that might have been most affected had the threshold been raised.

\section{Banking Institutions}

As of December 31, 2003, 9,095 banking institutions were subject to the CRA (table 1). We estimate that,

16. Under the proposal, intermediate small institutions would not be subject to the large-institution service test. The service test evaluates, among other things, the geographic distribution of an institution's branches and its record of opening and closing branches, as well as its record of providing community development services-that is, financial services targeted to lower-income people. Under the proposal, the branching of intermediate small institutions would no longer be evaluated although, under the proposed community development test, the community development services of such institutions would be.

17. For convenience, our research ignored the changes that the OTS made to its regulations and assumed that the OTS regulations are the 1995 regulations.

18. We used 2003 as a test year because at press time it was the latest year for which public data on retail lending activities related to the CRA were available. of those, 1,621 institutions that were considered large as of that date would be considered intermediate small or small under the agencies' 2005 CRA proposal (columns 1-3). These "status-changing" institutions constituted 18 percent of all institutions subject to the CRA, and they held 13 percent of the deposits held by all such institutions. Intermediate small institutions consisted of 1,264 institutions that had between $\$ 250$ million and $\$ 1$ billion in assets (column 2) and 116 institutions that had more than $\$ 1$ billion in assets but which would not be considered large under the proposal because of a proposed requirement to exceed the asset threshold for two consecutive years (column 3). The "newly small" institutions consisted of the 241 institutions that had assets of less than $\$ 250$ million but which nonetheless were subject to the large-institution CRA examination in 2003, generally because they were part of a bank holding company with assets of more than $\$ 1$ billion (column 1). ${ }^{19}$ These institutions would be considered small under the 2005 proposal. ${ }^{20}$

The 1,621 status-changing institutions differ from other CRA-covered institutions along a number of dimensions. First, 28 percent of the status-changing institutions had headquarters in nonmetropolitan areas, compared with 7 percent of institutions with assets exceeding $\$ 1$ billion and 52 percent of small banking institutions. Of the status-changing institutions with headquarters in nonmetropolitan areas, 60 percent had headquarters in exurban counties (nonmetropolitan counties adjacent to metropolitan areas) and 40 percent in remote counties (counties not adjacent to metropolitan areas). ${ }^{21}$ Second, 14 percent of the status-changing institutions had "outstanding" CRA performance ratings at their last examinations, compared with 37 percent of larger institutions and 11 percent of small institutions.

\section{Local Banking Markets}

Another way to look at the effect of raising the threshold is in terms of local banking markets. There

19. Fourteen of the 241 institutions were not part of a multibank holding company. They had exceeded the asset-size threshold for the large-institution examination as of the beginning of 2003, but their assets had fallen below $\$ 250$ million as of the end of the year. Under the 1995 regulations, these institutions had reverted to the smallinstitution examination as of the beginning of 2004 .

20. Nearly 380 of the status-changing institutions, although covered by the large-institution examination as of December 31, 2003, had last been evaluated under the CRA as small banking institutions (data shown under the "small-institution" subcategory); consequently, they had not yet been evaluated as "large."

21. In classifying rural counties, the U.S. Department of Agriculture makes the distinction between exurban and remote, among others. 
1. Banking institutions covered by the CRA, grouped by selected characteristics and distributed by asset size, as of December 31, 2003

Number except as noted

\begin{tabular}{|c|c|c|c|c|c|c|c|c|c|c|}
\hline \multirow{4}{*}{ Characteristic } & \multicolumn{7}{|c|}{ Type of iustitution, by asset size imillions of dollarsi } & & & \multirow{4}{*}{$\begin{array}{l}\text { Memo: } \\
\text { Share } \\
\text { of } \\
\text { deposits } \\
\text { (percent }\end{array}$} \\
\hline & \multirow{3}{*}{$\begin{array}{l}\text { Less } \\
\text { than } \\
250^{2}\end{array}$} & \multicolumn{3}{|c|}{ T.arges ir stitution ${ }^{1}$} & \multicolumn{3}{|c|}{ Small institutison' } & \multirow{2}{*}{\multicolumn{2}{|c|}{ To al }} & \\
\hline & & \multirow{2}{*}{$\begin{array}{l}250- \\
1,000\end{array}$} & \multicolumn{2}{|c|}{ More than 1,000} & \multirow{2}{*}{$\begin{array}{l}\text { Less } \\
\text { than } \\
150\end{array}$} & \multirow{2}{*}{$\begin{array}{l}150- \\
250\end{array}$} & \multirow{2}{*}{$\begin{array}{l}\text { More } \\
\text { than } \\
250^{4}\end{array}$} & & & \\
\hline & & & Recent $^{3}$ & Nonrecent & & & & Number & Percent & \\
\hline \multicolumn{11}{|l|}{$\begin{array}{l}\text { Location (headquarters) } \\
\text { Urban (metropolitan area) }\end{array}$} \\
\hline Center city ........... & 71 & 463 & 53 & 316 & 766 & 294 & 121 & 2,084 & 22.9 & 74.7 \\
\hline Suburban. & 81 & 456 & 47 & 101 & 1,633 & 415 & 153 & 2,886 & 31.7 & 15.0 \\
\hline \multicolumn{11}{|l|}{ Rural $^{5}$} \\
\hline Exurban $\quad \cdots . . .$. & 61 & 199 & 10 & 23 & 1,649 & 273 & 67 & 2,282 & 25.1 & 5.8 \\
\hline $\begin{array}{l}\text { Remote } \ldots \ldots \ldots \ldots \\
\text { U.S.-affiliated area }\end{array}$ & $\begin{array}{r}28 \\
0\end{array}$ & $\begin{array}{r}144 \\
2\end{array}$ & $\begin{array}{l}5 \\
1\end{array}$ & $\begin{array}{l}8 \\
9\end{array}$ & $\begin{array}{r}1,417 \\
6\end{array}$ & $\begin{array}{r}182 \\
0\end{array}$ & $\begin{array}{r}41 \\
0\end{array}$ & $\begin{array}{r}1,825 \\
18\end{array}$ & 20.1 & $\begin{array}{r}3.7 \\
8\end{array}$ \\
\hline \multicolumn{11}{|l|}{ Rating on most recent $C R A$ exam } \\
\hline Outstanding . ................. & 34 & 164 & 26 & 168 & 573 & 165 & 50 & 1,180 & 13.0 & 54.3 \\
\hline Satisfactory ..... & 185 & 1,050 & 84 & 282 & 4,405 & 918 & 293 & 7,217 & 79.4 & 42.9 \\
\hline Needs to improve & 0 & 7 & 1 & 0 & 27 & 0 & 1 & 36 & .4 & .1 \\
\hline Substantial noncompliance . & 0 & 0 & 0 & 1 & 3 & 0 & 0 & 4 & .0 & .0 \\
\hline None (no exam in 5 years) & 22 & 43 & 5 & 6 & 463 & 81 & 38 & 658 & 7.2 & 2.7 \\
\hline \multicolumn{11}{|l|}{ Type of most recent CRA exam } \\
\hline Large-institution .............. & 129 & 909 & 95 & 412 & 6 & $0^{2}$ & 2 & 1,555 & 17.1 & 80.2 \\
\hline Small-institution ... & 79 & 291 & 9 & 3 & 4,973 & 1,075 & 339 & 6,769 & 74.4 & 12.8 \\
\hline Other $^{7} \ldots \ldots \ldots \ldots$ & 11 & 21 & 7 & 36 & 29 & 6 & 3 & 113 & 1.2 & 4.3 \\
\hline None (no exam in 5 years) & 22 & 43 & 5 & 6 & 463 & 81 & 38 & 658 & 7.2 & 2.7 \\
\hline \multicolumn{11}{|l|}{ Current regulator 8} \\
\hline Board .............. & 20 & 162 & 14 & 62 & 497 & 124 & 46 & 925 & 10.2 & 17.4 \\
\hline FDIC $\ldots \ldots$ & 136 & 639 & 57 & 163 & 3,413 & 627 & 222 & 5,257 & 57.8 & 24.4 \\
\hline OCC $\ldots . . . . . . .$. & 70 & 298 & 22 & 145 & 1,100 & 280 & 77 & 1,992 & 21.9 & 44.1 \\
\hline OTS $\ldots \ldots \ldots \ldots \ldots \ldots \ldots \ldots \ldots$ & 15 & 165 & 23 & 87 & 461 & 133 & 37 & 921 & 10.1 & 14.2 \\
\hline \multicolumn{11}{|l|}{ All } \\
\hline 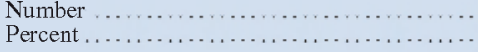 & $\begin{array}{r}241 \\
2.7\end{array}$ & $\begin{array}{r}1,264 \\
13.9\end{array}$ & $\begin{array}{l}116 \\
1.3\end{array}$ & $\begin{array}{r}457 \\
5.0\end{array}$ & $\begin{array}{r}r, 4 / 1 \\
60.1\end{array}$ & $\begin{array}{r}1,167 \\
12.8\end{array}$ & $\begin{array}{r}382 \\
4.2\end{array}$ & $\begin{array}{l}9,095 \\
\ldots\end{array}$ & 100 & 100 \\
\hline \multicolumn{11}{|l|}{ MEMO } \\
\hline $\begin{array}{l}\text { Median number of days between exams } \\
\text { Share of deposits (percent) }\end{array}$ & 1,703 & $\begin{array}{r}963 \\
9.6\end{array}$ & $\begin{array}{r}927 \\
2.9\end{array}$ & $\begin{array}{r}1,035 \\
75.6\end{array}$ & $\begin{array}{r}1,734 \\
6.0\end{array}$ & $\begin{array}{r}1,734 \\
3.6\end{array}$ & $\begin{array}{r}1,657 \\
1.9\end{array}$ & 1,645 & 100 & 100 \\
\hline
\end{tabular}

Note. Here and in subsequent tables, "CRA" means Community Reinvestment Act, and components may not sum to totals because of rounding.

1. Large institutions are banking institutions that reported 2003 data on small-business, small-farm, or community development lending as required of large institutions under the CRA. All other institutions are small institutions.

2. These institutions are generally part of multibank holding companies with assets of more than $\$ 1$ billion and are currently covered by the largeinstitution CRA exam.

3. "Recent" institutions are banking institutions that had more than $\$ 1$ billion in assets as of December 31,2003, but not in the two consecutive years before 2003. If the asset-size threshold had been raised to $\$ 1$ billion as of yearend 2003, these institutions would not yet have qualified for the largeinstitution CRA exam.

4. These institutions had more than $\$ 250$ million in assets as of December 31,2003 , but failed to qualify for the large-institution CRA exam because they had not held this amount of assets for two consecutive years.

5. Exurban areas are counties adjacent to metropolitan areas; remote areas are counties not adjacent to metropolitan areas.

6. In this article, U.S.-affiliated areas consist of American Samoa, Guam, the Commonwealth of the Northern Mariana Islands, Puerto Rico, and the U.S. Virgin Islands.

7. "Other" exams cover strategic-plan, wholesale, and limited-purpose institutions. A strategic-plan institution develops its own plan, subject to the approval of a supervising agency, for evaluating its CRA performance. A wholesale institution does not extend home mortgage, small-business, smallfarm, or consumer loans to retail customers; a limited-purpose institution offers

a narrow product line, such as one composed of credit card or motor vehicle loans, to a regional or broader market. Exams for wholesale and limitedpurpose institutions are limited to community development activities.

8. Current regulators are the Board of Governors of the Federal Reserve System (Board), the Federal Deposit Insurance Corporation (FDIC), the Office of the Comptroller of the Currency (OCC), and the Office of Thrift Supervision (OTS).

$$
\text { - Not applicable. }
$$

Sources. Here and in subsequent tables, except as noted, analyses incorporate data from one or more of the following sources: unemployment, Bureau of Labor Statistics (2002); assets and business loans (as of June 30, 2003; data adjusted through December 31, 2003 , to reflect changes in banking institution structure), Consolidated Reports of Condition and Income (Call Report), Federal Deposit Insurance Corporation (2003); branches and deposits (as of June 30, 2003; data adjusted through December 31, 2003, to reflect changes in banking institution structure), Summary of Deposits, Federal Deposit Insurance Corporation (2003); filings under the Home Mortgage Disclosure Act and the Community Reinvestment Act, Federal Financial Institutions Examination Council (2003); metropolitan statistical areas, Office of Management and Budget (2004); census tracts, U.S. Census Bureau (2000); net migration, Estimated Components of Population Change, Population Estimates program, U.S. Census Bureau (2000); poverty, Small Area Income and Poverty Estimates program, U.S. Census Bureau (2002); rural area designations, Urban Influence Codes, Economic Research Service, U.S. Department of Agriculture (2003).

is no universally accepted geographic definition of local banking markets, but the Federal Reserve Banks have constructed a list of local banking market definitions for reviews of the competitive effects of proposed mergers and acquisitions, and we used these

definitions in our analysis. ${ }^{22}$ Not all parts of the country have been defined for this purpose; however,

22. Local banking markets are not necessarily equivalent to CRA assessment areas. Unlike CRA assessment areas, local banking markets are not drawn from the perspective of a particular institution. 
the 1,873 defined markets account for 96.7 percent of the branches and 97.7 percent of the deposits held by banking institutions nationwide (table 2). Seventy percent of banking markets are rural, but such markets account for a relatively small proportion of banking deposits nationwide (about one-eighth-data omitted from table) because most people and businesses are located in metropolitan areas.

For the market analysis, we focused on markets in which status-changing institutions play a significant role. We used two methods to characterize the roles of status-changing institutions in their markets: the percentage of a market's deposits held by status-changing institutions and the determination of whether a status-changing institution is the largest institution in the market.

The first method, the "market-share method," classifies markets by the percentage of each market's deposits held by status-changing institutions. This method assumes that an institution's propensity to invest in its market is directly related to its share of the market's deposits. (Here, we use the word "invest" in its broadest sense to include extensions of credit, services, grants, and equity investments.) The method further assumes that all institutions that shift from a large-institution examination to a smallinstitution examination experience the same proportional change in their propensity to invest in the market. These assumptions imply that the markets with the greatest presence (as measured by share of market deposits) of status-changing institutions will experience the largest proportional changes in banking institutions' lending and investing in the market.
2. Bank branches and deposits, grouped by location and distributed by market status of location. as of December 31, 2003

\begin{tabular}{|c|c|c|c|c|c|}
\hline \multirow{2}{*}{ Ttem } & \multirow{2}{*}{ Urban } & \multicolumn{2}{|c|}{ Rural } & \multirow{2}{*}{$\begin{array}{c}\text { U.S.- } \\
\text { affiliated } \\
\text { area }\end{array}$} & \multirow{2}{*}{ Total } \\
\hline & & Exurban & Remote & & \\
\hline \multirow{3}{*}{$\begin{array}{l}\text { Branches } \\
\text { Number } \\
\text { In defined markets } \\
\text { Not in defined } \\
\text { markets } \\
\text { Total ...... }\end{array}$} & & & & & \\
\hline & & 10,234 & 7,806 & 0 & 84,855 \\
\hline & $\begin{array}{r}612 \\
67.427\end{array}$ & $\begin{array}{r}1,034 \\
11,268\end{array}$ & $\begin{array}{r}606 \\
8,412\end{array}$ & $\begin{array}{l}641 \\
641\end{array}$ & $\begin{array}{r}2,893 \\
87748\end{array}$ \\
\hline Percent & & & & & \\
\hline $\begin{array}{l}\text { In defined markets } \\
\text { Not in defined }\end{array}$ & 99.1 & 90.8 & 92.8 & 0 & 96.7 \\
\hline $\begin{array}{c}\text { markets ...... } \\
\text { Total ............ }\end{array}$ & $\begin{array}{r}99 \\
100\end{array}$ & $\begin{array}{r}9.2 \\
100\end{array}$ & $\begin{array}{r}7.2 \\
100\end{array}$ & $\begin{array}{l}100 \\
100\end{array}$ & $\begin{array}{r}3.3 \\
100\end{array}$ \\
\hline $\begin{array}{l}\text { Share of deposits } \\
\text { (percent) } \\
\text { In defined markets }\end{array}$ & 99.4 & 91.8 & 92.7 & 0 & 97.7 \\
\hline $\begin{array}{l}\text { Not in defined } \\
\text { markets } \ldots . . . \\
\text { Total } \ldots \ldots \ldots . . .\end{array}$ & $\begin{array}{r}.6 \\
100\end{array}$ & $\begin{array}{r}8.2 \\
100\end{array}$ & $\begin{array}{r}7.3 \\
100\end{array}$ & $\begin{array}{l}100 \\
100\end{array}$ & $\begin{array}{r}2.3 \\
100\end{array}$ \\
\hline $\begin{array}{l}\text { MEMo } \\
\text { Number of defined } \\
\text { markets } \ldots . . .\end{array}$ & 563 & 693 & 617 & 0 & 1,873 \\
\hline $\begin{array}{l}\text { Share of deposits in } \\
\text { defined markets } \\
\text { (percent) } \\
\text { Share of deposits not in }\end{array}$ & 88.7 & 6.9 & 4.4 & 0 & 100 \\
\hline $\begin{array}{l}\text { defined markets } \\
\text { (percent) ............. } \\
\text { Average number of }\end{array}$ & 21.1 & 26.3 & 14.9 & 37.7 & 100 \\
\hline $\begin{array}{l}\text { headquarters per } \\
\text { defined market }\end{array}$ & 19.1 & 7.0 & 6.3 & 0 & 10.4 \\
\hline
\end{tabular}

NotE. In this article, markets are those defined as local banking markets by the Federal Reserve Banks; these defined areas do not cover all parts of the country. For markets that span more than one type of area, location is determined by the area with the largest percentage of market deposits. For definitions of "exurban" and "remote," see table 1, note 5. For definition of "U.S.affiliated area," see table 1 , note 6.

3. Banking markets grouped by location and distributed by share of market deposits held by institutions that would shift from large-institution to small-institution CRA examinations under the agencies' 2005 proposal, as of December 31, 2003 Percent except as noted

\begin{tabular}{|c|c|c|c|c|c|c|}
\hline \multirow{2}{*}{ Location of market ${ }^{1}$} & \multicolumn{5}{|c|}{ Share of ma'ket deposits affested ipercenti } & \multirow{2}{*}{ Total } \\
\hline & 0 & $1-10$ & $11-20$ & $21-50$ & $51-100$ & \\
\hline \multicolumn{7}{|l|}{ Urban } \\
\hline Number & 88 & 145 & 123 & 173 & 34 & 563 \\
\hline Percent $\ldots \ldots \ldots \ldots \ldots \ldots \ldots \ldots \ldots$ & 15.6 & 25.8 & 21.9 & 30.7 & 6.0 & 100 \\
\hline Percent weighted by market deposits ... & .7 & 60.8 & 26.3 & 11.1 & 1.1 & 100 \\
\hline \multicolumn{7}{|l|}{ Rural } \\
\hline $\begin{array}{l}\text { Exurban } \\
\text { Number }\end{array}$ & 215 & 100 & 95 & 196 & 87 & 693 \\
\hline Percent & 31.0 & 14.4 & 13.7 & 28.3 & 12.6 & 100 \\
\hline Percent weighted by market deposits & 16.9 & 28.9 & 14.1 & 28.5 & 11.5 & 100 \\
\hline \multicolumn{7}{|l|}{ Remote } \\
\hline Number & 218 & 61 & $\begin{array}{r}88 \\
113\end{array}$ & 185 & 65 & 617 \\
\hline $\begin{array}{l}\text { Percent } \\
\text { Percent weighted by market deposits }\end{array}$ & $\begin{array}{l}35.3 \\
17.7\end{array}$ & $\begin{array}{r}9.9 \\
15.7\end{array}$ & 14.3 & 30.0 & 10.5 & 100 \\
\hline Percent we1ghted by market deposits ......... & 11.1 & 13.7 & 17.3 & 39.0 & 9.8 & 100 \\
\hline \multicolumn{7}{|l|}{ 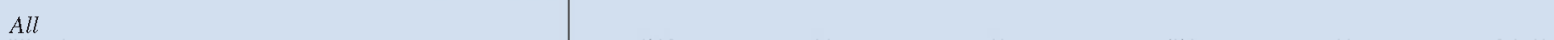 } \\
\hline $\begin{array}{l}\text { Number } \ldots \ldots \ldots \ldots \ldots \ldots \ldots \ldots \ldots \\
\text { Percent }\end{array}$ & $\begin{array}{r}521 \\
278\end{array}$ & $\begin{array}{l}306 \\
16.3\end{array}$ & $\begin{array}{r}306 \\
16.3\end{array}$ & $\begin{array}{r}554 \\
29.6\end{array}$ & $\begin{array}{r}186 \\
9.9\end{array}$ & $\begin{array}{r}1,873 \\
100\end{array}$ \\
\hline Percent weighted by market deposits ..... & 2.6 & 56.6 & 25.0 & 13.6 & 2.2 & 100 \\
\hline
\end{tabular}


The second method of market analysis, the "largest-institution method," classifies markets by the size of the largest institution with a presence (office) in the market regardless of the market share of that institution. This method assumes that if raising the threshold has an effect, the effect is particularly large in those markets that go from having one or more institutions that are subject to the threepart large-institution examination to having no such institutions.

As noted earlier. the market-share method idenlifies the share of markel deposits held by staluschanging institutions (table 3). As of December 31, 2003,28 percent of the nation's 1,873 banking markets (with 3 percent of nationwide deposits) had no status-changing institution located within the market (column 1). Under either the marketshare or the largest-institution method, those markets would presumably be unaffected by raising the threshold to $\$ 1$ billion. In another one-third of markets (with 82 percent of nationwide deposits), status-changing institutions held less than 20 percent of deposits and thus, under the market-share method, would likely not see major effects (columns 2 and 3 ). But in roughly 10 percent of markets (with 2 percent of nationwide deposits),
4. Banking markets, grouped by location and distributed by change in CRA reporting status of largest banking institution with an office in the market, as of December 31, 2003

Percent except as noted

\begin{tabular}{|c|c|c|c|c|}
\hline Location of market & $\begin{array}{c}\text { Remains } \\
\text { small }\end{array}$ & $\begin{array}{c}\text { Large } \\
\text { changes } \\
\text { to } \\
\text { small }\end{array}$ & $\begin{array}{c}\text { Remains } \\
\text { large }\end{array}$ & Total \\
\hline Urban & & & & \\
\hline Number. & 25 & 19 & 519 & 563 \\
\hline Percent & 4.4 & 3.4 & 92.2 & 100 \\
\hline $\begin{array}{l}\text { Percent weighted } \\
\text { by market deposits }\end{array}$ & .1 & .1 & 99.9 & 100 \\
\hline $\begin{array}{l}\text { Rural } \\
\text { Exurban }\end{array}$ & & & & \\
\hline Number. & 51 & 50 & 592 & 693 \\
\hline Percent & 7.4 & 7.2 & 85.4 & 100 \\
\hline $\begin{array}{l}\text { Percent weighted } \\
\text { by market deposits }\end{array}$ & 2.2 & 3.0 & 94.8 & 100 \\
\hline $\begin{array}{l}\text { Remote } \\
\text { Number }\end{array}$ & 98 & 89 & 430 & 617 \\
\hline 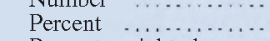 & 15.9 & 14.4 & 69.7 & 100 \\
\hline $\begin{array}{l}\text { Percent weighted } \\
\text { by market deposits }\end{array}$ & 4.3 & 7.5 & 88.2 & 100 \\
\hline All & & & & \\
\hline Number. & 174 & 158 & 1,541 & 1,873 \\
\hline Percent & 9.3 & 8.4 & 82.3 & 100 \\
\hline $\begin{array}{l}\text { Percent weighted } \\
\text { by market deposits }\end{array}$ & .4 & .6 & 99.0 & 100 \\
\hline
\end{tabular}

NotE. See notes to table 3.

5. Characteristics of counties in markets considered potentially most affected by an increase in the large-institution threshold to $\$ 1$ billion, by method of market analysis

Percent except as noted

\begin{tabular}{|c|c|c|c|c|c|}
\hline \multirow{3}{*}{ Characteristic } & \multicolumn{4}{|c|}{ Methxd of market analysis and location of market ${ }^{1}$} & \multirow{3}{*}{$\begin{array}{l}\text { National } \\
\text { average } \\
\text { for rural } \\
\text { counties }\end{array}$} \\
\hline & \multicolumn{2}{|c|}{ Market-share } & \multicolumn{2}{|c|}{ Largest-institution } & \\
\hline & Urban & Rural & Urban & Rural & \\
\hline \multicolumn{6}{|l|}{ Demographic } \\
\hline Poverty rate, 2002 ............. & 12.6 & 14.0 & 12.5 & 16.0 & 15.0 \\
\hline $\begin{array}{l}\text { Income per capita, } 2001 \text { (dollars) } \\
\text { Real income growth rate }\end{array}$ & 24,304 & 25,481 & 21,827 & 21,040 & 21,908 \\
\hline $\begin{array}{l}\text { Real income growth rate } \\
1996-2001\end{array}$ & 6.8 & 7.0 & 6.2 & 5.7 & 1.7 \\
\hline $1981-2001 \quad \ldots \ldots \ldots \ldots$ & 33.3 & 33.0 & 30.0 & 26.9 & 28.1 \\
\hline $\begin{array}{l}\text { Unemployment rate, } 2001 \\
\text { Population growth rate }\end{array}$ & 5.2 & 5.4 & 5.4 & 5.4 & 5.7 \\
\hline $\begin{array}{l}\text { Unemployment rate, } 2001 \\
\text { Population growth rate }\end{array}$ & 5.8 & 2.8 & 4.6 & -1 & 17 \\
\hline $1981-2001 \quad \ldots \ldots \ldots \ldots \ldots \ldots$ & 22.6 & 22.5 & 13.5 & $\begin{array}{r}.1 \\
.1\end{array}$ & 10.5 \\
\hline 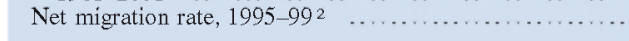 & 2.4 & 1.6 & 4.5 & .7 & 1.2 \\
\hline \multicolumn{6}{|l|}{ Banking } \\
\hline \multicolumn{6}{|l|}{ Branches per 10,000 persons } \\
\hline $\begin{array}{l}\text { Number, } 2003 \\
\text { Change, } 1998-2003 \ldots \ldots . . .\end{array}$ & $\begin{array}{l}4.0 \\
-3.3\end{array}$ & $\begin{array}{l}5.0 \\
-.2\end{array}$ & $\begin{array}{l}4.6 \\
-3\end{array}$ & 6.2 & 5.4 \\
\hline \multicolumn{6}{|l|}{ Deposits } \\
\hline $\begin{array}{l}\text { Per capita (thousands of dollars), } 2003 \\
\text { Change, } 1998-2003 \ldots \ldots \ldots \ldots \ldots \ldots \ldots\end{array}$ & 12.8 & $\begin{array}{l}14.5 \\
-?\end{array}$ & 10.9 & 15.2 & 14.0 \\
\hline \multirow{2}{*}{\multicolumn{6}{|c|}{ Memo: Counties (data as of 2000) }} \\
\hline & & 190 & 14 & 160 & 20513 \\
\hline Percent with no lower-income tracts . & 21.4 & 48.2 & 50.0 & 55.0 & $48.2^{3}$ \\
\hline Percent with only lower-income tracts & .0 & 3.0 & 7.1 & 7.5 & $5.5^{3}$ \\
\hline \multicolumn{2}{|c|}{$\begin{array}{l}\text { 1. For markets that span more than one type of area, location is deter- } \\
\text { mined by the area with the largest percentage of market deposits. Hence, rural } \\
\text { counties may be located in urban markets. When market boundaries do not } \\
\text { correspond to county boundaries, the county is assigned to the market with the } \\
\text { largest share of deposits. Under the market-share method, potentially most- } \\
\text { affected markets are markets in which status-changing institutions (those with } \\
\text { assets between } \$ 250 \text { million and } \$ 1 \text { billion) held more than } 50 \text { percent of market }\end{array}$} & \multicolumn{4}{|c|}{$\begin{array}{l}\text { deposits. Under the large-institution method, potentially most-affected mar- } \\
\text { kets are markets in which the largest institution with an office in the market } \\
\text { was a status-changing institution (one with assets between } \$ 250 \text { million and } \\
\$ 1 \text { billion). } \\
\text { 2. Net migration rate is calculated as the difference in migration between } \\
1999 \text { and } 1995 \text { relative to the estimated population in } 1997 \text {. } \\
\text { 3. U.S. total. }\end{array}$} \\
\hline
\end{tabular}




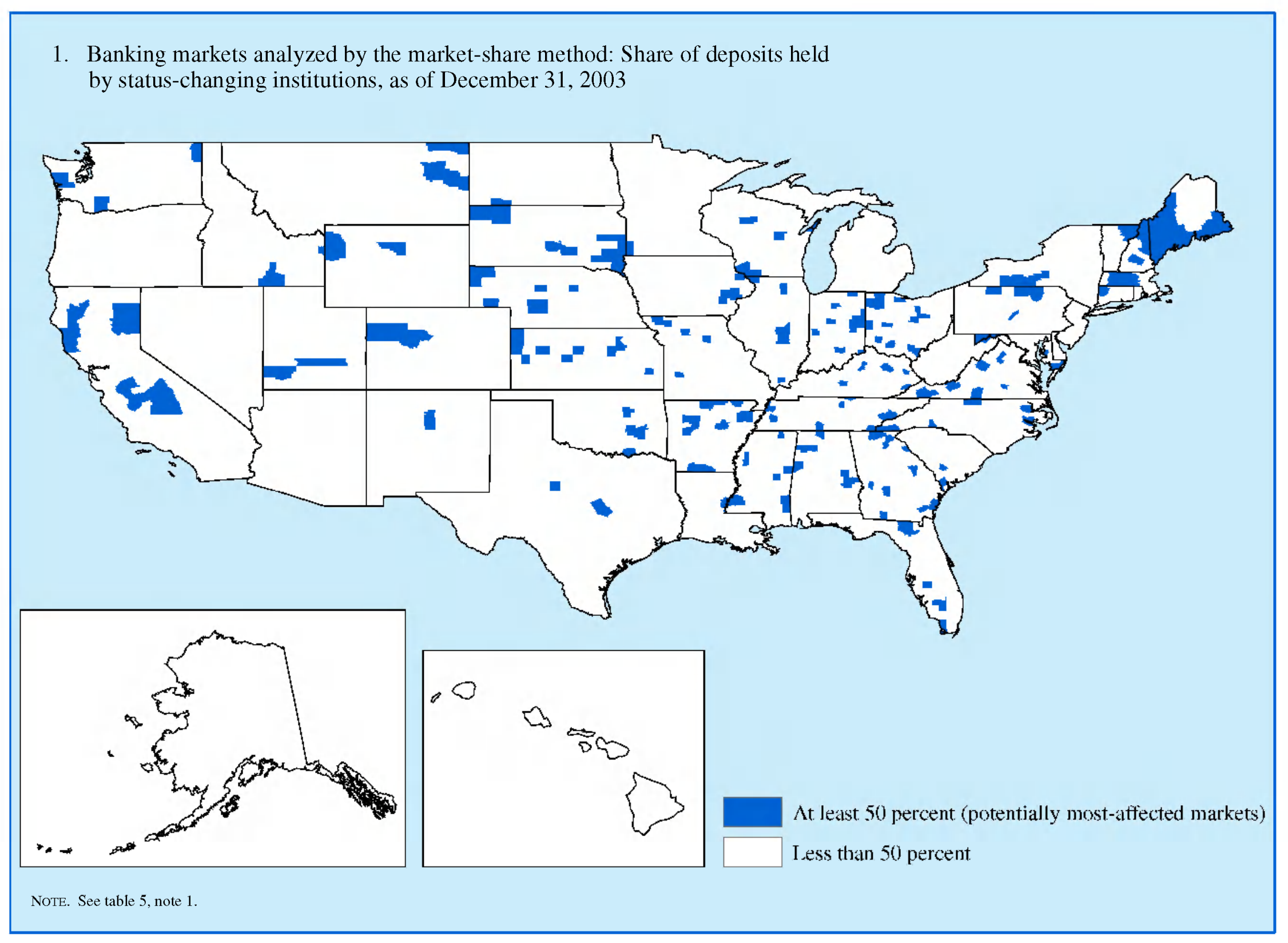




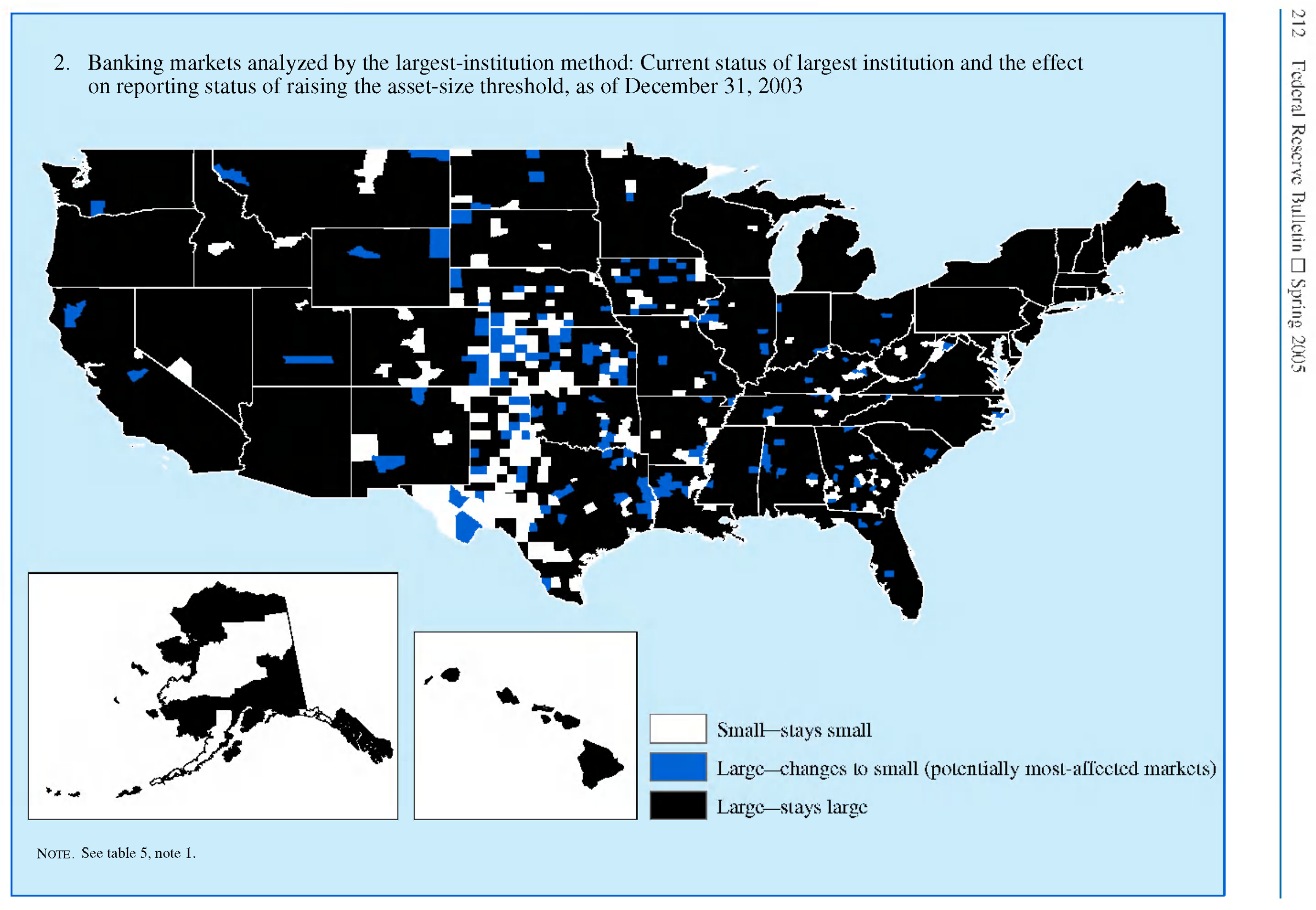


status-changing institulions held more than 50 percent of market deposits and, consequently, those markets have the potential to be most affected (column 5).

The largest-institution method yields a different group of potentially most affected markets (table 4). The largest institution was a status-changing institution in about 8 percent of all markets (with less than 1 percent of nationwide deposits) (column 2).

Although there is little overlap between the groups of potentially most affected markets defined by the two methods, the groups have several characteristics in common (table 5). In both groups, the markets are overwhelmingly rural, are served by few banking institutions (data omitted from table), have unemployment rates near the national rural average, and have bank branches per capita similar to the national rural average. Yet the groups of markets differ in key respects. Whereas population growth is much higher than the national rural average in the potentially most affected markets identified by the market-share method, it is notably lower than the national rural average in such markets identified by the largestinstitution method. Moreover, under the market-share method, the potentially most affected markets are scattered throughout the country (figure 1), but under the largest-institution method, such markets are concentrated substantially in the Great Plains region, with much smaller concentrations in Iowa, Louisiana, Kentucky-Tennessee, and southern Georgia-northern Florida (figure 2). ${ }^{23}$

\section{Results of Threshold Tests}

The 2005 proposal would subject intermediate small banking institutions to the streamlined lending test currently applied to smaller institutions and would eliminate the service (branching) test for intermediate small institutions. Testing directly to determine how those changes would affect activities of intermediate small institutions is impossible. However, an inference might be drawn from the effect of the current $\$ 250$ million threshold on the retail lending and branching activities of institutions with assets near this threshold. Of particular interest are the retail lending activities covered by both the largeinstitution and the streamlined lending tests. Our tests compare the retail lending and branching of institutions just above and just below the current largeinstitution threshold of $\$ 250$ million (table 6). Institu-

23. The figures use counties, which approximate, rather than precisely match, banking markets. tions "just below" the threshold are defined here as those that had between $\$ 150$ million and $\$ 250$ million in assets as of December 31, 2003, and were deemed small as of that date and for the purposes of their most recent CRA performance evaluation (group 1); institutions "just above" the threshold are defined as those that had between $\$ 250$ million and $\$ 350$ million in assets and were deemed large as of that date and for the purposes of their most recent examination (group 2).

Banking institutions in these two groups were restricted to institutions that were independent of multibank holding companies, that had a CRA examination completed between January 1, 1999, and June 30, 2004, and that received a "satisfactory" CRA performance rating on their most recent examination in that period. Institutions with "outstanding" ratings were excluded to control for the possibility that such institutions were influenced less by the nature of their CRA examinations and more by other factors, such as institution philosophy, than were institutions with "satisfactory" ratings. Institutions with less than "satisfactory" ratings were excluded for similar reasons. Institutions with headquarters in U.S.-affiliated areas were also excluded.

The threshold test relies on sources of data that provide the same types of information for institutions just above the threshold as for institutions just below. The information consists of five balance sheet ratios constructed from dollar values provided in Call Report data supplied to federal banking agencies. ${ }^{24}$ The ratios compose two categories: loan dollars to deposits (overall; consumer; and business, including small commercial and industrial [C\&I], small commercial real estate [CRE], and small farm) and mortgage dollars to deposits (one- to four-family and multifamily).

In addition, five measures of retail lending to lower-income populations were constructed from filings pursuant to HMDA: the percentage of an institution's home-purchase and home-improvement loans extended to lower-income borrowers or census tracts and a comparable calculation for loans extended for multifamily housing in lower-income census tracts. Each of the HMDA-based measures was expressed as the difference between the percentage of the institution's retail loans made to lower-income borrowers (or borrowers that live in lower-income tracts) and the percentage of the families that live in the areas

24. "Call Report" is the informal name for the Report of Condition and Income, which commercial banking institutions must file each quarter with federal and state banking agencies. It is essentially equivalent to the Thrift Financial Report, which savings institutions must file each quarter with the Office of Thrift Supervision. 
6. Lending and branching activities of banking institutions with asset sizes close to the current large-institution threshold for CRA exams, as of December 31, 2003

Percent except as noted

\begin{tabular}{|c|c|c|c|c|c|c|}
\hline \multirow{2}{*}{ Item } & \multicolumn{4}{|c|}{$\begin{array}{l}\text { Asse size } \\
\text { (millions of disllirs) }\end{array}$} & \multicolumn{2}{|c|}{$\begin{array}{l}\text { ME no: } \\
\text { Crossed threshinsld } \\
\text { after end of } 2 \text { inji. }{ }^{1}\end{array}$} \\
\hline & $\begin{array}{l}150-250 \\
\text { (Group 1) }\end{array}$ & $\begin{array}{l}250-350 \\
\text { (Group 2) }\end{array}$ & $\begin{array}{l}350-450 \\
\text { (Group 3) }\end{array}$ & $\begin{array}{l}\text { Less than } 250^{2} \\
\text { (Group } 4)\end{array}$ & 2001 & 2003 \\
\hline Ratio of loan dollars to deposits, by type of loan & \multirow{3}{*}{$\begin{array}{r}78.6^{1,13} \\
5.6^{\mathrm{a}, \mathrm{B}}\end{array}$} & \multirow{3}{*}{$\begin{array}{r}83.7^{\circ} \\
7.0^{\circ}\end{array}$} & \multirow{3}{*}{$\begin{array}{r}78.5 \\
5.0\end{array}$} & \multirow{3}{*}{$\begin{array}{r}88.5 \\
8.6\end{array}$} & \multirow{3}{*}{$\begin{array}{l}85.3 \\
6.4^{d}\end{array}$} & \multirow{3}{*}{$\begin{array}{r}85.4 \\
5.1\end{array}$} \\
\hline $\begin{array}{l}\text { All } \quad \ldots \ldots \ldots \ldots \ldots \ldots \ldots \ldots \ldots \ldots \ldots \\
\text { Consumer }\end{array}$ & & & & & & \\
\hline Business $^{3} \ldots$ & & & & & & \\
\hline \multicolumn{7}{|l|}{ Commercial and industrial } \\
\hline Overall $\ldots . . . \ldots \ldots \ldots . . .$. & 11.2 & 9.9 & 10.3 & 12.3 & 11.4 & 10.7 \\
\hline \multicolumn{4}{|l|}{ Conmmercial real estate } & 9.7 & 9.3 & 8.0 \\
\hline Overall ............... & 19.0 & 20.9 & 19.8 & 20.4 & $17.9 \mathrm{~d}$ & 20.9 \\
\hline Small $\ldots \ldots \ldots \ldots \ldots$ & 13.9 & 13.1 & 11.8 & 13.2 & 12.8 & 13.5 \\
\hline \multicolumn{7}{|l|}{ Farm $^{4}$} \\
\hline Overall ....... & $5.5^{\mathrm{a}}$ & 3.3 & 3.8 & 6.0 & 6.9 & 6.4 \\
\hline Small $\ldots . . . . .$. & $6.6^{\mathrm{a}}$ & 4.1 & 5.9 & 5.6 & 8.4 & 7.3 \\
\hline \multirow{2}{*}{\multicolumn{7}{|c|}{$\begin{array}{l}\text { Ratio of mortgage dollars to deposits, by type of mortgage } \\
1-4 \text { family }\end{array}$}} \\
\hline & $27.0^{\mathrm{a}, \mathrm{b}}$ & 29.9 & 27.6 & 31.8 & 33.0 & 29.9 \\
\hline & 2.2 & 2.6 & 2.5 & 2.2 & 4.0 & 4.7 \\
\hline \multicolumn{7}{|l|}{ Loans to lower-income borrowers (percentage points) ${ }^{5}$} \\
\hline Home-purchase & -3.7 & -3.3 & -3.2 & -4.5 & ... & ... \\
\hline Home-improvement $\ldots .$. & 10.0 & 10.8 & 7.6 & 4.6 & $\cdots$ & $\cdots$ \\
\hline \multicolumn{7}{|l|}{ Loans in lower-income areas ${ }^{5}$} \\
\hline Home-purchase............. & -7.8 & -10.6 & -4.8 & -14.2 & .. & ... \\
\hline Home-improvement $\ldots$ & -4.5 & -7.5 & -6.9 & -.7 & .. & ... \\
\hline Multifamily $\ldots . . . . . . . .$. & 1.6 & 7.3 & 8.1 & -.6 & .. & ... \\
\hline \multicolumn{7}{|l|}{ Branching activity ${ }^{6}$} \\
\hline Branches per $\$ 100$ million of deposits (number) & 2.9 & 2.7 & 2.7 & 3.0 & 3.1 & 2.9 \\
\hline Branches in lower-income areas (percentage points). & -1.7 & 1.0 & -3.5 & -1.8 & .. & ... \\
\hline 5 -year change in such branches $\ldots \ldots \ldots \ldots \ldots \ldots \ldots$ & .0 & -1.0 & -2.0 & -1.5 & $\cdots$ & $\cdots$ \\
\hline Number of institutions & 646 & 72 & 142 & 49 & 100 & 100 \\
\hline
\end{tabular}

NoTE. Data are group means adjusted for state, institution (savings association or commercial bank), location (center city, suburban, exurban, or remote), and charter effects. Analysis is restricted to institutions that were examined in the past five years, that were in existence for at least one year, and that received a "satisfactory" rating on the small- or large-institution exam. Data exclude institutions with headquarters in U.S.-affiliated areas and strategic-plan, wholesale, and limited-purpose institutions (see table 1, note 7).

1. Data are for the 100 banking institutions that were subject to the smallinstitution evaluation in 2001 but were subject to the large-institution evaluation in 2002 and 2003. Differences are omitted for retail loans extended to lower-income borrowers, retail loans extended in lower-income areas, and some categories of branching activity because the lower-income classifications of 2001 were based on the 1990 census, whereas those of 2003 were based on the 2000 census.

2. These institutions are part of multibank holding companies with assets of more than $\$ 1$ billion and are currently covered by the large-institution CRA exam

3. Business loan ratios are calculated as of June 30, 2001, or June 30, 2003, for comparability with small-loan data. Data have been adjusted through December 2001 or December 2003 to reflect changes in banking institution structure.

4. Farm lending is measured only for rural commercial banks. Small farm contains some loans not in overall farm.

served by the institution who have lower incomes (or live in lower-income tracts). Because of limitations on reporting requirements for rural institutions under HMDA, the comparisons that use the HMDA-based lower-income lending measures were restricted to retail lending activities in urban areas.

We present means of these metrics for the groups above and below the threshold, adjusted to remove effects related to state, institution type (savings association or commercial bank), and headquarters

5. Data cover only urban tracts and institutions that report data under the Home Mortgage Disclosure Act. Data are the difference between the average percentage of lending to borrowers in lower-income census tracts and the average percentage of families that live in lower-income census tracts in the areas that the institutions serve.

6. Branch data are measured as of June 30, 1998; June 30, 2001; or June 30 , 2003. Data have been adjusted through December 1998, December 2001, or December 2003 to reflect changes in banking institution structure. Data on lower-income areas are the difference between the percentage of branches in lower-income census tracts and the percentage of families that live in lowerincome census tracts in the areas that the institutions serve.

a. Difference between group 1 and group 2 is statistically significant at the 10 percent level.

b. Difference between group 1 and group 4 is statistically significant at the 10 percent level

B. Difference between group 1 and group 4 is statistically significant at the 1 percent level.

c. Difference between group 2 and group 3 is statistically significant at the 10 percent level.

d. Difference between ratio in 2001 and that in 2003 is statistically significant at the 10 percent level.

.. Not applicable.

location (center city, suburban, exurban, remote) as rough controls for economic and demographic factors. ${ }^{25}$ The results are of three types. First, overall C\&I lending, CRE lending (overall or small), multifamily housing, and the HMDA data measures show no statistically significant differences. Second, the

25. Every institution in the analysis had at least one comparable institution on the other side of the threshold in the same state, of the same institution type, and in the same area type. 
other business loan categories do show differences that are statistically significant; however, the direction of the differences is the opposite of what would have been expected had the differences been caused by tougher evaluation criteria in the large-institution evaluation.

Third, statistically significant differences exist in the groups' ratios of overall loan dollars to deposits, consumer loan dollars to deposits, and one- to fourfamily mortgage dollars to deposits, and these differences go in the direction that might suggest a threshold effect. To confirm that this result reflects differences in CRA evaluation criteria and not merely in asset size, we conducted an additional comparison test. We constructed a third group of banking institutions that had between $\$ 350$ million and $\$ 450$ million in assets and that otherwise met the same requirements as the institutions in group 2 (group 3). A comparison of adjusted means for group 3 with those for group 2 isolates the effects of size differences because banking institutions in both groups are subject to the same type of CRA evaluation. Institutions in group 3 have lower ratios of overall loan dollars to deposits, consumer loan dollars to deposits, and one- to four-family mortgage dollars to deposits than have institutions in group 2 (and, in two out of three cases, lower than those of group 1 institutions), an indication that the difference between groups 1 and 2 may be caused by a factor other than the difference in CRA examination types.

We also compared adjusted means for groups 1 and 2 (and for groups 2 and 3) on three measures of branching activity: (1) the number of branches per $\$ 100$ million of deposits, (2) the difference between the percentage of branches in lower-income census tracts and the percentage of the population that lives in lower-income census tracts in the areas that the institutions serve, and (3) the five-year change in the percentage of branches in lower-income areas. None of the three measures shows a significant difference among any of the groups.

As a further test for the effects of differences in CRA evaluation types, we compared independent institutions that had between $\$ 150$ million and $\$ 250$ million in assets (group 1) with similarly sized institutions that were subject to the large-institution evaluation criteria because of their affiliation with holding companies with assets of $\$ 1$ billion or more (group 4). The ratios of overall loan dollars to deposits, consumer loan dollars to deposits, and one- to four-family mortgage dollars to deposits are the only measures with a statistically significant difference: Group 4 has higher ratios than does group 1. One should interpret these results cautiously, as they may mean only that banking institutions in holding companies are more likely than independent banking institutions to raise funds through wholesale, nondeposit markets and to be institutions focused on retail lending.

A final test for the effects of differences in CRA evaluation types examined whether banking institutions that passed the $\$ 250$ million threshold measurably changed their retail lending and branching activities. Specifically, one hundred institutions covered by the large-institution CRA evaluation (though not necessarily yet evaluated as large institutions) at the end of 2002 and at the end of 2003 had been subject to the small-institution evaluation in 2001. This test, unlike the other tests, looked for any change in an individual institution's behavior induced by a change in evaluation type. We restricted the comparison to institutions covered by the large-institution examination for both 2002 and 2003 to ensure that ample time had elapsed for behavioral changes to result in measurable changes in balance sheet variables. We found only two statistically significant changes in retail lending or branching behavior as an institution passed through the $\$ 250$ million threshold (compare columns 5 and 6 ), but the changes were in opposite directions: Consumer lending fell, and overall CRE lending rose.26

Taken together, the threshold tests provide little evidence that the nature of the CRA examination influences the retail lending and branching activities of banking institutions in the size range near the $\$ 250$ million threshold. However, the threshold tests have an important limitation. The tests are limited to inferences about the behavior of institutions around the margin of the current threshold, $\$ 250$ million. They suggest that raising the threshold some amount above $\$ 250$ million would not have a significant effect on retail lending or branching. However, they fail to reveal what amount of increase in the threshold, if any, would result in a significant effect.

\section{The Role of Community Development Lending}

The 1995 regulations require that, for a large institution, community development lending be evaluated as only one component of the CRA lending test, which includes a wide range of other, retail types of

\footnotetext{
26. We refrained from conducting the comparison for any of the measures that use lower-income classifications because 2001 classifications were based on the 1990 census and 2003 classifications were based on the 2000 census. The change in classifications makes a comparison of lower-income activity in 2001 with lower-income activity in 2003 problematic.
} 
lending (see box "The Large-Institution Evaluation"). Under the 2005 proposal, intermediate small institutions would be subject to a new community development test. Instead of considering community development loans, investments, and services in three separate tests, the proposal is for the three types of activity to be considered in a single test. The proposal responds in part to the argument that community development lending is more like community development investments - both are primarily for the benefit of lower-income people or areas-than like retail lending. It also responds to the argument that evaluating community development investments separately from retail lending places too much emphasis on investment vehicles, especially for smaller institutions that have limited experience with and opportunities for investments and substantially more experience with and opportunities for retail lending.

We could not test for the effects of adopting a community development test on community development loans, investments, or services. We could, however, consider whether the number or dollar amount of community development loans have played a significant role in CRA ratings. Our sample was restricted to institutions examined under the largeinstitution examination between January 1, 2001, and December 31, 2003. We looked at the institutions' community development lending records over the same period (table 7). The data suggest that an institution's community development lending record is largely unrelated to its overall CRA rating. The lack of relationship is most apparent among institutions with assets of more than $\$ 5$ billion: Nearly one-half

7. Rating on most recent CRA exam and community development lending during 2001-03 at large institutions, by rating and asset size of institution, as of December 31, 2003

Percent except as noted

\begin{tabular}{|c|c|c|c|c|}
\hline \multirow{2}{*}{$\begin{array}{l}\text { Number of institutions } \\
\text { and status of community } \\
\text { development lending, } \\
\text { by CRA rating }\end{array}$} & \multicolumn{4}{|c|}{ 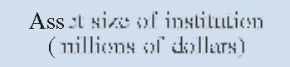 } \\
\hline & $\begin{array}{c}250- \\
500\end{array}$ & $\begin{array}{l}500 \\
1,000\end{array}$ & $\begin{array}{c}1,000- \\
5,000\end{array}$ & $\begin{array}{c}\text { More } \\
\text { than } \\
5,000\end{array}$ \\
\hline \multicolumn{5}{|l|}{ Outstanding } \\
\hline Number of institutions & 23 & 50 & 92 & 65 \\
\hline Made no loans.................. & 26.1 & 22.0 & 8.7 & 6.2 \\
\hline Ranked in bottom half of asset-size class .. & 39.1 & 44.0 & 38.0 & 46.2 \\
\hline Satisfactory & & & & \\
\hline Number of institutions $\quad \ldots \ldots \ldots \ldots \ldots \ldots$. & 241 & 316 & 254 & 69 \\
\hline Made no loans $\ldots \ldots \ldots \ldots \ldots . . . . . . . . . .$. & 29.9 & 19.0 & 11.0 & 5.8 \\
\hline Ranked in bottom half of asset-size class ... & 51.0 & 51.0 & 54.3 & 53.6 \\
\hline
\end{tabular}

Note. Analysis is restricted to institutions that were subject to the largeinstitution CRA exam each year from 2001 through 2003 , that were in existence for at least one year, that received an "outstanding" or "satisfactory" rating on the exam, and that had assets of more than $\$ 250$ million in 2003. Data exclude strategic-plan, wholesale, or limited-purpose institutions (see table 1, note 7) and institutions with headquarters in U.S.-affiliated areas. of the institutions with "outstanding" ratings had community development lending activity in the bottom half of their asset-size group. Among intermediate small institutions, those with "outstanding" ratings were a little more likely than their counterparts with "satisfactory" ratings to do community development lending. However, fully one-fourth of the institutions rated "outstanding" in this category did no community development lending, and about 40 percent had community development lending activity in the bottom half of their asset-size group.

Although the data provide no information about how community development lending should be treated in CRA evaluations, they do suggest that such lending is not currently critical in overall CRA ratings. The likely explanation is that, because examiners consider community development loans as part of a comprehensive lending test, other types of lending may have compensated for an institution's lack of community development loans. Another possibility is that, despite the mandate of the regulations to treat community development loans and community development investments separately, examiners implicitly treat them as substitutes.27

\section{COMMUNITY DEVELOPMENT AND RURAL AREAS}

Another part of the agencies' 2005 proposal would expand the definition of "community development" in rural, though not urban, areas. This part of the proposal would cover banking institutions of all sizes, not just intermediate small institutions.

\section{The Problem and the Agencies' Proposed Solution}

The regulations' current definition of "community development" is identical for urban and rural areas. As noted earlier, the definition covers four categories of activity, three of which (affordable housing, com-

27. Some empirical support exists for the substitutability explanation. We examined the CRA performance evaluation reports (PEs) for the twenty-three institutions in our sample that had assets between $\$ 250$ million and $\$ 500$ million and that received "outstanding" CRA ratings (column 1 , row 1 , of table 7 ). There is a mild negative correlation $(-.2)$ between the dollar volume of community development lending and the investments reported in the PEs. However, some evidence also suggests that the substitutability explanation applies only to smaller institutions. An examination of the dollar volume of community development lending and the investments reported in the PEs of the fifty institutions in our sample that had assets between $\$ 500$ million and $\$ 1$ billion and that received "outstanding" CRA ratings (column 2, row 1) shows a significant positive correlation of 5 . 
8. Distribution of census tracts, population, and families, by location of tract and tract income relative to wider area, as of December 31, 2003

Percent except as noted

\begin{tabular}{|c|c|c|c|c|c|}
\hline \multirow{2}{*}{$\begin{array}{l}\text { Census tract location } \\
\text { and percent of median } \\
\text { family income in area }{ }^{1}\end{array}$} & \multicolumn{2}{|c|}{ Census tracts } & \multirow{2}{*}{$\begin{array}{l}\text { Popu- } \\
\text { lation }\end{array}$} & \multirow{2}{*}{ Families } & \multirow{2}{*}{$\begin{array}{l}\text { Memo: } \\
\text { Families } \\
\text { with } \\
\text { incomes } \\
\text { less } \\
\text { than } \\
80 \text { percent } \\
\text { of MSA } \\
\text { or } \\
\text { non-MSA } \\
\text { median }^{2}\end{array}$} \\
\hline & Number & Percent & & & \\
\hline \multicolumn{6}{|l|}{ Urban } \\
\hline \multicolumn{6}{|l|}{$\begin{array}{l}\text { Income relative to } \\
\text { MSA }\end{array}$} \\
\hline Less than 50 & 3,437 & 13.1 & 10.0 & 8.7 & 78.2 \\
\hline $50-79 \quad \ldots \ldots \ldots$ & 8,004 & 30.5 & 29.7 & 27.7 & 60.5 \\
\hline $80-90 \quad \ldots \ldots \ldots$ & 2,622 & 10.0 & 10.4 & 10.3 & 45.8 \\
\hline $90-100$. & 2,503 & 9.5 & 10.0 & 10.2 & 39.4 \\
\hline $100-119 \quad \ldots \ldots$ & 3,898 & 14.8 & 16.3 & 17.4 & 31.6 \\
\hline 120 or more $\ldots$ & 5.814 & 22.1 & 23.6 & 25.7 & 19.0 \\
\hline \multirow{2}{*}{\multicolumn{6}{|c|}{$\begin{array}{l}\text { Income relative to } \\
\text { state }\end{array}$}} \\
\hline & & & & & \\
\hline Less than 80 & 10,938 & 41.6 & 37.8 & 34.8 & 64.8 \\
\hline $80-99 \quad \ldots \ldots \ldots$ & 4,851 & 18.5 & 19.2 & 19.3 & 42.9 \\
\hline $100-119$ & 3,900 & 14.8 & 15.9 & 16.7 & 31.8 \\
\hline 120 or more $\ldots$ & 6,589 & 25.1 & 27.0 & 29.2 & 18.0 \\
\hline Total ...... & 26,278 & 100 & 100 & 100 & 41.4 \\
\hline \multicolumn{6}{|l|}{$\begin{array}{l}\text { Suburban tracts } \\
\text { Income relative to } \\
\text { MSA }\end{array}$} \\
\hline Less than 50 & 444 & 1.7 & 1.2 & 1.0 & 76.9 \\
\hline $50-79 \ldots \ldots$ & 4,456 & 16.9 & 15.9 & 14.6 & 57.9 \\
\hline $80-90 \quad \ldots \ldots \ldots$ & 3,384 & 12.9 & 12.5 & 12.3 & 45.6 \\
\hline $90-100 \quad \ldots \ldots \ldots$ & 4,069 & 15.5 & 15.5 & 15.5 & 38.9 \\
\hline $100-119 \quad \ldots \ldots$ & 6,563 & 25.0 & 25.6 & 26.2 & 30.7 \\
\hline 120 or more.. & 7,382 & 28.1 & 29.2 & 30.4 & 18.5 \\
\hline Total $\quad . . . .$. & 26,298 & 100 & 100 & 100 & 34.5 \\
\hline \multicolumn{6}{|l|}{$\begin{array}{l}\text { Income relative to } \\
\text { state }\end{array}$} \\
\hline Less than $80 \ldots$ & 4,592 & 17.5 & 159 & 14.4 & 59.7 \\
\hline $80-99 \ldots \ldots \ldots$ & 6,333 & 24.1 & 23.5 & 23.3 & 42.2 \\
\hline $100-119 \quad \ldots \ldots$ & 6,100 & 23.2 & 23.8 & 24.1 & 30.8 \\
\hline 120 or more $\ldots$ & 9,273 & 35.3 & 36.8 & 38.2 & 17.6 \\
\hline Total & 26,298 & 100 & 100 & 100 & 32.6 \\
\hline \multicolumn{6}{|l|}{$\begin{array}{l}\text { Rural } \\
\text { Exurban tracts }\end{array}$} \\
\hline \multicolumn{6}{|l|}{$\begin{array}{l}\text { Income relative to } \\
\text { non-MSA }\end{array}$} \\
\hline Less than $50 \quad \ldots$ & 57 & .7 & .5 & .4 & 72.9 \\
\hline $50-79 \ldots \ldots \ldots$ & 912 & 11.9 & 10.5 & 9.8 & 55.1 \\
\hline $80-90 \quad \ldots \ldots \ldots$ & 1.157 & 15.1 & 14.4 & 14.1 & 45.8 \\
\hline $90-100 \quad \ldots \ldots$ & 1,780 & 23.2 & 22.7 & 22.8 & 39.8 \\
\hline $100-119 \quad \ldots \ldots$ & 2,720 & 35.5 & 36.9 & 37.4 & 32.6 \\
\hline 120 or more ... & 1,035 & 13.5 & 15.0 & 15.5 & 23.7 \\
\hline Total ....... & 7,661 & 100 & 100 & 100 & 37.1 \\
\hline \multicolumn{6}{|l|}{$\begin{array}{l}\text { Income relative to } \\
\text { state }\end{array}$} \\
\hline Less than $80 \quad \ldots$ & 3,051 & 39.8 & 37.5 & 36.3 & 57.4 \\
\hline $80 \quad 99 \quad \ldots \ldots \ldots$ & 3,394 & 44.3 & 45.0 & 45.7 & 43.4 \\
\hline $100-119 \quad \ldots \ldots$ & 1,006 & 13.1 & 14.5 & 14.9 & 33.0 \\
\hline 120 or more $\ldots$ & 210 & 2.7 & 3.0 & 3.1 & 22.9 \\
\hline Total ....... & 7.661 & 100 & 100 & 100 & 46.3 \\
\hline \multirow{2}{*}{\multicolumn{6}{|c|}{$\begin{array}{l}\text { Remote tracts } \\
\text { Income relative to } \\
\text { non-MSA }\end{array}$}} \\
\hline & & & & & \\
\hline Less than 50 & 39 & .8 & .6 & .4 & 72.0 \\
\hline $50-79 \ldots \ldots$ & 794 & 17.1 & 15.0 & 14.4 & 55.8 \\
\hline $80-90 \quad \ldots \ldots \ldots$ & 927 & 19.9 & 18.7 & 18.7 & 46.1 \\
\hline $90-100 \quad \ldots \ldots \ldots$ & 1,136 & 24.4 & 23.4 & 23.8 & 39.9 \\
\hline $100-119$ & 1,285 & 27.6 & 29.6 & 30.0 & 32.9 \\
\hline 120 or more .... & 469 & 10.1 & 12.7 & 12.8 & 23.3 \\
\hline Total ......... & 4,650 & 100 & 100 & 100 & 39.3 \\
\hline \multicolumn{6}{|l|}{$\begin{array}{l}\text { Income relative to } \\
\text { state }\end{array}$} \\
\hline $\begin{array}{l}\text { state } \\
\text { Less than } 80\end{array}$ & 2.240 & 48.2 & 44.6 & 43.9 & 58.6 \\
\hline $80-99 \ldots \ldots \ldots$ & 1.764 & 37.9 & 38.4 & 38.9 & $\begin{array}{l}50.0 \\
43.7\end{array}$ \\
\hline $100-119$ & 487 & 10.5 & 12.5 & 12.6 & 33.1 \\
\hline 120 or more $\ldots$ & 159 & 3.4 & 4.6 & 4.5 & 23.5 \\
\hline Total ........ & 4,650 & $100^{\circ}$ & 100 & 100 & 48.0 \\
\hline
\end{tabular}

\section{8.-Continued}

Percent except as noted

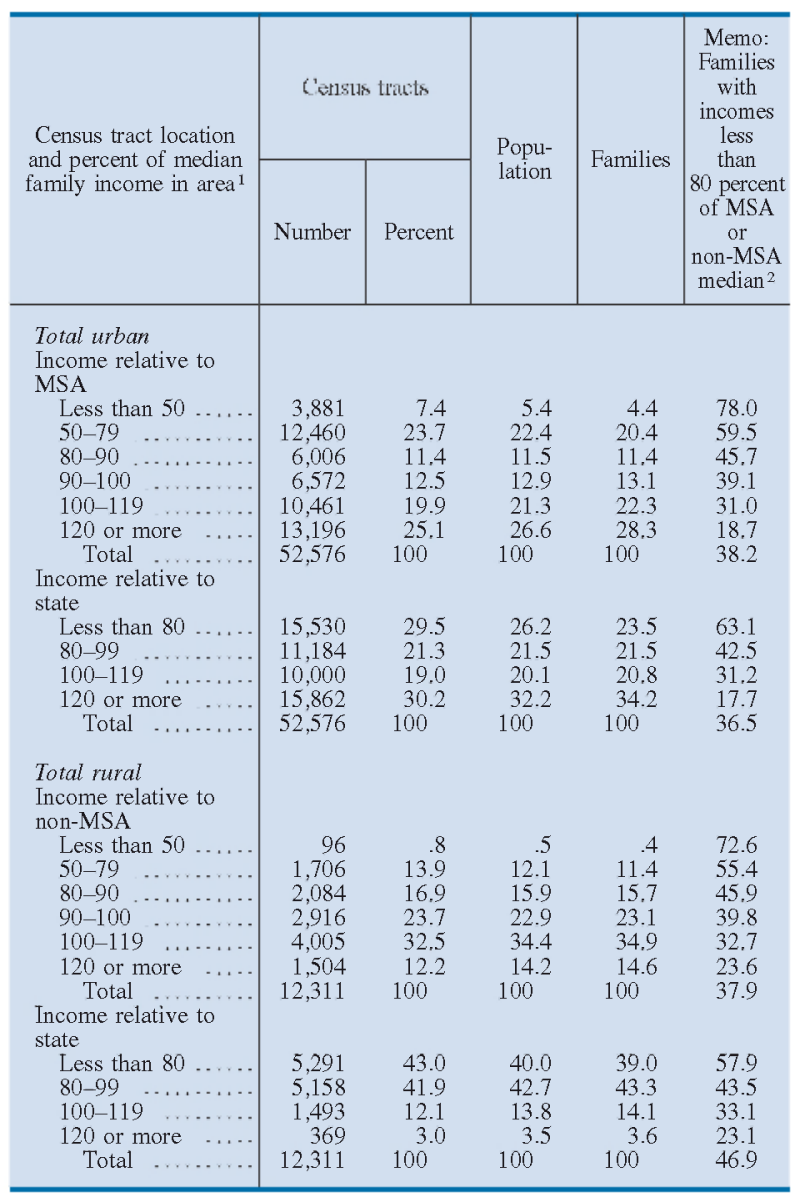

NoTE. Data from the 2000 census are reported for census tracts and metropolitan statistical areas as determined by 2004 definitions. Data exclude census tracts in U.S.-affiliated areas.

1. Income standard is the median family income in the metropolitan statistical area (MSA), nonmetropolitan portion of the state (non-MSA), or state in which the census tract is located.

2. For calculations in this column, even when tracts are classified by state standards, families are still classified by the income in the MSA or non-MSA in which the family is located.

munity services, and economic development) are defined in terms of the activity's targeting of certain recipients (lower-income people, small businesses, or small farms) and the fourth of which (revitalization and stabilization) is defined in terms of the activity's targeting of certain areas-namely, lower-income census tracts.

Some have said that the lower-income-area limitation in the fourth category, revitalization and stabilization, may unduly constrain the effectiveness of the regulations in promoting community development activities in rural areas. In response to such concerns, the agencies proposed to expand the definition of "community development" to include revitalizing or 
stabilizing aclivilies in underserved rural areas. No such change was proposed for urban areas.

The problem that the agencies sought to address stems in part from the way rural census tracts are classified. As applied to rural areas, the 1995 regulations' system for classifying census-tract income has two defining characteristics. The first characteristic is that the system ignores the fact that rural areas are generally poorer than urban areas. Forty-three percent of rural census tracts in the United States (containing 40 percent of the rural population) have a median family income below 80 percent of the median family income of the state in which the tracts are located; in contrast, 30 percent of urban census tracts (containing 26 percent of the urban population) have a median family income below 80 percent of the statewide median (table 8, "Total rural" and "Total urban" categories). But the 1995 regulations classify rural census tracts relative only to a state's rural median income, not relative to the median income of the entire state, including its urban areas. Thus, the current rule classifies only 15 percent of rural tracts, not 43 percent, as lower income. In contrast, despite the higher absolute incomes of urban areas, double the proportion of urban tracts ( 31 percent), which are classified relative to the relevant metropolitan area income, are currently classified as lower income.

The second characteristic is that the census tract identifies pockets of lower-income populations less effectively in rural areas than in urban areas. Compared with urban census tracts, rural tracts are drawn over relatively large geographic areas, have lower population densities, and often have relatively heterogeneous populations that, when averaged, tend toward the middle (table 9). Indeed, 73 percent of all rural tracts are defined as middle income; in contrast, 44 percent of urban tracts are defined as such (percentages derived from table 8).

The large size of rural census tracts and the relative heterogeneity within them have another consequence: uneven distribution of lower-income tracts among areas that define banking institutions' markets, such as counties and assessment areas. Most rural counties (almost 60 percent) have no tracts that are classified as lower income under the current definition; in contrast, only 18 percent of urban counties are without any such tracts (table 9). About 44 percent of the rural assessment areas that large institutions reported under the CRA regulation in 2003 lacked any tracts classified as lower income, whereas only 14 percent of the urban assessment areas that these institutions reported lacked any such tracts. Small institutions do not report their assessment areas, though the areas are described in their performance evaluations. A rough approximation of a small institution's assessment areas-one that uses the counties in which its branches are located - suggests that 54 percent of small institutions also lack any lower-income tracts in rural areas.

The relative lack of lower-income tracts in rural areas could have different consequences. Banking institutions might invest less, or less efficiently, in

9. Characteristics of census tracts and the share of selected areas and of banking institutions without lower-income tracts, by location of tract, as of December 31, 2003

Percent except as noted

\begin{tabular}{|c|c|c|c|c|c|c|c|}
\hline \multirow{2}{*}{ Item } & \multicolumn{2}{|c|}{ Urban } & \multicolumn{2}{|c|}{ Rural } & \multicolumn{3}{|c|}{ Total } \\
\hline & Center city & Suburban & Exurban & Remote & Urban & Rural & All \\
\hline \multicolumn{8}{|l|}{ Characteristic of census tract } \\
\hline Number of tracts $\ldots \ldots \ldots \ldots \ldots \ldots \ldots . . .$. & 26,278 & 26,298 & 7,661 & 4,650 & 52,576 & 12,311 & 64,887 \\
\hline Average land area per tract (square miles) ... & 5.5 & 28.5 & 147.8 & 322.7 & 17.0 & 213.9 & 54.3 \\
\hline $\begin{array}{l}\text { Average population density per tract } \\
\text { (population per square mile) }\end{array}$ & $9,812.3$ & $3,097.3$ & 494.5 & 423.4 & 6.454 .4 & 467.7 & 53184 \\
\hline Average population per tract $\ldots . . . . . . .$. & $4,145.3$ & $4,693.8$ & $4,163.7$ & $3,639.6$ & $4,419.6$ & $3,965.7$ & $4,333.4$ \\
\hline Percent of national population $\ldots \ldots \ldots \ldots \ldots \ldots \ldots$ & 38.7 & 43.9 & 11.3 & 6.0 & 82.6 & 17.4 & 100.0 \\
\hline \multicolumn{8}{|l|}{ Share without lower-income census tracts } \\
\hline 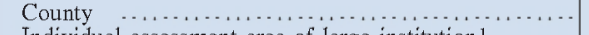 & 12.0 & 31.9 & 56.9 & 61.3 & 18.0 & 59.0 & 44.8 \\
\hline Individual assessment area of large institution ${ }^{1} \quad \ldots \ldots$. & 6.2 & 26.5 & 45.1 & 45.7 & 13.8 & 43.8 & 23.4 \\
\hline $\begin{array}{l}\text { Aggregate assessment area } \\
\text { Large institution }\end{array}$ & 58 & 143 & 360 & 327 & 54 & 303 & 130 \\
\hline 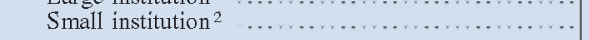 & $\ldots$ & $\ldots$ & 55.0 & 56.9 & 7.9 & 53.9 & 28.3 \\
\hline $\begin{array}{l}\text { NotE. Data exclude U.S.-affiliated areas and tract } \\
\text { information. } \\
\text { 1. An assessment area consists of the area in which a ban } \\
\text { its main office, branches, and deposit-taking automated telle } \\
\text { as the surrounding areas in which the institution has origi } \\
\text { a substantial portion of its loans. Assessment areas rep } \\
\text { geographies, which were determined from information su } \\
\text { Census Bureau, the U.S. Department of Agriculture, and the }\end{array}$ & $\begin{array}{l}\text { without in } \\
\text { king institutio } \\
\mathrm{r} \text { machines, as } \\
\text { nated or purcl } \\
\text { orted in the } \\
\text { pplied by the } \\
\text { Office of Ma }\end{array}$ & $\begin{array}{ll}\text { me } & \mathrm{m} \\
\text { has } & \text { th } \\
\text { vell } & \mathrm{m} \\
\text { sed } & \\
\text { jed } & \text { sn } \\
\text { U.S. }\end{array}$ & $\begin{array}{l}\text { and Budget } \\
\text { Dffice of } \mathrm{M} \\
\text { tical areas. } \\
\text { have multip } \\
\text { Aggregate } \\
\text { institutions } \\
\text {. Not appli }\end{array}$ & $\begin{array}{l}\text { ve been ma } \\
\text { ement anstitutio } \\
\text { sessment } \\
\text { sment are } \\
\text { branches. }\end{array}$ & $\begin{array}{l}\text { donto the } \\
\text { dget's } 200 \\
\text { eport their } \\
\text { correspon } \\
\text { ere approx }\end{array}$ & $\begin{array}{l}7 \text { tract defir } \\
\text { esignation } \\
\text { ssment ar } \\
\text { to cities } \\
\text { ed by the }\end{array}$ & $\begin{array}{l}\text { s, which use } \\
\text { metropolitan } \\
\text { ach year and } \\
\text { tes. } \\
\text { ies in which }\end{array}$ \\
\hline
\end{tabular}


community-improving activities in rural areas than they might under a standard more appropriate for rural community development. Or they might shift more of their community-improving loans or investments to urban areas than they might under a standard that would give more equal area-based CRA consideration in urban and rural areas. A third possibility is that, even if the first and second possibilities failed to occur, banking institutions might receive inadequate recognition of their community-improving activities in rural areas because the activities did not meet the exact requirements to qualify as community development.

Perhaps to address these possible consequences, the 2005 proposal would expand, in two ways, the criteria under which banking institutions receive CRA consideration for community-improving activities in rural areas. First, CRA consideration would be available for activities that revitalize or stabilize "underserved rural areas," in the words of the proposal, even if the areas lack lower-income tracts. Second, the proposal would extend CRA consideration to affordable housing for any individual in an underserved rural area. The 1995 regulations limit affordable housing consideration to housing for lower-income individuals; consideration does not depend on where the lower-income individuals reside. The proposal would leave unchanged the recognition of community development activities in urban areas and the non-community-development CRA measures.

In this section, we analyze several issues related to the agencies' proposal to expand the criteria for recognizing rural community-improving activities as community development. First, we test the proposal's premise that the 1995 regulations "disfavor" community-improving activities in rural areas relative to those in urban areas. Second, we explore the implications of various options to revise the regulations on which the agencies sought public comment.

\section{Concern about Whether the 1995 Regulations "Disfavor" Rural Areas}

Research on the question of whether the 1995 regulations disfavor rural areas is constrained by the difficulties in gathering comprehensive data on community-improving activities that fail to qualify for CRA consideration and by the lack of geographic data on community development loans, investments, and services. However, geographic data are available for all other CRA-related loan products and branches, such as loans to purchase or improve homes or to finance small businesses or small farms. We used these data to test whether large institutions whose assessment areas include both urban and rural areas ("urban-rural institutions") appear to favor urban areas over rural areas in retail lending and branching activities. We also tested whether large institutions with headquarters in rural areas ("rural institutions") were less likely than similarly situated institutions with headquarters in urban areas ("urban institutions") (1) to receive "outstanding" CRA ratings or (2) to engage in community development lending.

The first test was based on the distribution of urban-rural institutions' activities between urban and rural parts of their assessment areas. We restricted the analysis to institutions covered by the largeinstitution examination as of December 31, 2003 , because such institutions are required to report the geographic location of most of their CRA-related loans, with the notable exception of community development loans. The test involved two distinct comparisons. First, the test compared the distribution of numbers of retail loans between urban and rural parts with the distributions of offices, populations (families), and housing structures (owner-occupied or multifamily) between the parts. This comparison tested whether urban-rural institutions extend retail loans in the same proportion to the offices, populations, and housing structures of those areas (table 10). ${ }^{28}$ Second, the test compared, for various types of retail loan in those institutions' assessment areas, the distribution of loan dollars between urban and rural parts with the distribution of deposits between the parts. The comparison tested whether urban-rural institutions extend loan dollars in the same proportion that they receive deposits in rural and urban areas (table 11). We conducted both comparisons separately for banking institutions in four asset-size categories: $\$ 250$ million to $\$ 500$ million, $\$ 500$ million to $\$ 1$ billion, $\$ 1$ billion to $\$ 5$ billion, and more than $\$ 5$ billion.

We found that remote areas receive more retail loans as measured against the distributions of offices, populations, and housing structures and more loan dollars as measured against the distribution of deposits than do urban areas in the aggregate for banking institutions of every size category and for retail loans of almost every type considered (tables 10 and 11). For example, urban-rural institutions with assets between $\$ 500$ million and $\$ 1$ billion received 13.6 percent of their deposits from branches in

28. We also conducted a similar analysis that restricted the comparisons to retail loans, retail loan dollars, offices, families, housing structures, and deposits in lower-income tracts. The results for this comparison are substantially the same as those for the comparison based on the full set of census tracts. 
10. Number of retail loans, offices, families, and housing structures in the assessment areas of large banking institutions with both urban and rural branches, grouped by asset size of institution and distributed by location of assessment area, as of December 31, 2003

Percent

\begin{tabular}{|c|c|c|c|c|c|c|}
\hline \multirow{2}{*}{ Asset size of institution and characteristic } & \multicolumn{2}{|c|}{ Ur: an } & \multicolumn{2}{|c|}{ Rtral } & \multicolumn{2}{|c|}{ Toal } \\
\hline & Center city & Suburban & Exurban & Remote & Urban & Rural \\
\hline \multicolumn{7}{|l|}{$\begin{array}{l}\$ 250 \text { million to } \$ 500 \text { million } \\
\text { Loans }\end{array}$} \\
\hline $\begin{array}{l}\text { Loans } \\
\text { Home-purchase } \ldots \ldots \ldots \ldots\end{array}$ & 22.3 & 30.6 & 27.7 & 19.5 & 52.9 & 47.1 \\
\hline Home-improvement & 10.5 & 32.6 & 38.3 & 18.6 & 43.0 & 57.0 \\
\hline Small-business or small-farm & 13.7 & 25.2 & 31.6 & 29.6 & 38.8 & 61.1 \\
\hline Multifamily .................. & 42.4 & 24.7 & 24.1 & 8.8 & 67.0 & 33.0 \\
\hline $\begin{array}{l}\text { Offices } \\
{ }^{1}\end{array}$ & $\begin{array}{l}4.4 \\
20.9\end{array}$ & 28.2 & 35.8 & 15.1 & 49.2 & 50.9 \\
\hline Families $\quad . . . \ldots \ldots$. & 35.1 & 40.8 & 14.6 & 9.4 & 76.0 & 24.0 \\
\hline \multicolumn{7}{|l|}{ Housing structures } \\
\hline Owner-occupied & 32.2 & 42.4 & 15.5 & 9.8 & 74.7 & 25.3 \\
\hline Multifamily ............. & 59.4 & 29.6 & 5.8 & 5.2 & 89.0 & 11.0 \\
\hline \multicolumn{7}{|l|}{$\$ 500$ million to $\$ 1$ billion } \\
\hline \multicolumn{7}{|l|}{$\begin{array}{l}\text { \$50u million to \$1 billion } \\
\text { Loans }\end{array}$} \\
\hline Home-purchase ... & 25.7 & 31.1 & 22.2 & 21.1 & 56.8 & 43.2 \\
\hline Home-improvement $\ldots \ldots \ldots$ & 21.5 & 30.6 & 28.4 & 19.5 & 52.1 & 47.9 \\
\hline Small-business or small-farm & 19.2 & 23.1 & 27.1 & 30.6 & 42.3 & 57.7 \\
\hline Multifamily & 51.6 & 20.6 & 13.5 & 14.3 & 72.2 & 27.8 \\
\hline Offices $^{1} \ldots . . . .$. & 24.2 & 31.6 & $\begin{array}{l}10.3 \\
29.4\end{array}$ & 14.8 & 55.8 & 44.2 \\
\hline Families ............ & 33.6 & 46.3 & 11.5 & 8.5 & 79.9 & 20.1 \\
\hline \multicolumn{7}{|l|}{ Housing structures } \\
\hline Owner-occupied & 30.9 & 47.5 & 12.6 & 9.1 & 78.3 & 21.7 \\
\hline Multifamily ..... & 54.2 & 38.0 & 3.9 & 3.8 & 92.7 & 7.3 \\
\hline \multicolumn{7}{|l|}{$\$ 1$ billion to $\$ 5$ billion } \\
\hline \multicolumn{7}{|l|}{$\begin{array}{l}\text { Loans } \\
\text { Lon to } \$ \text { y billion }\end{array}$} \\
\hline Home-purchase $\ldots$ & 34.6 & 38.4 & 15.6 & 11.4 & 73.0 & 27.0 \\
\hline Home-improvement $\ldots \ldots \ldots$ & 23.7 & 36.6 & 23.4 & 16.3 & 60.3 & 39.7 \\
\hline Small-business or small-farm & 31.4 & 28.2 & 20.0 & 20.4 & 59.5 & 40.5 \\
\hline Multifamily & 55.9 & 24.5 & 9.4 & 10.2 & 80.3 & 19.7 \\
\hline Offices $^{1} \ldots . . . .$. & 32.7 & 34.2 & 22.2 & 10.9 & 66.9 & 33.1 \\
\hline Families ............ & 39.0 & 48.7 & 7.4 & 4.9 & 87.7 & 12.3 \\
\hline \multicolumn{7}{|l|}{ Housing structures } \\
\hline Owner-occupied & 36.2 & 50.8 & 7.9 & 5.2 & 87.0 & 13.0 \\
\hline Multifamily ..... & 57.8 & 37.1 & 2.6 & 2.5 & 94.9 & $\begin{array}{r}13.0 \\
5.1\end{array}$ \\
\hline \multicolumn{7}{|l|}{ More than $\$ 5$ billion } \\
\hline \multicolumn{7}{|l|}{$\begin{array}{l}\text { More than \$5 Dillion } \\
\text { Loans }\end{array}$} \\
\hline Home-purchase $\ldots$ & 36.7 & 53.7 & 4.7 & 4.8 & 90.4 & 9.6 \\
\hline Home-improvement $\ldots \ldots \ldots$ & 29.9 & 54.6 & 8.9 & 6.6 & 84.5 & 15.5 \\
\hline Small-business or small-farm & 39.1 & 44.8 & 8.2 & 8.0 & 83.9 & 16.1 \\
\hline 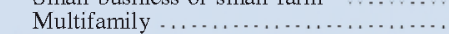 & 59.7 & 34.0 & 3.1 & 3.1 & 93.8 & 6.2 \\
\hline Offices $^{1} \ldots \ldots \ldots$ & 41.2 & 45.2 & 9.0 & 4.5 & 86.4 & 13.5 \\
\hline Families ......... & 40.0 & 52.6 & 4.0 & 3.3 & 92.7 & 7.3 \\
\hline \multicolumn{7}{|l|}{ Housing structures } \\
\hline Owner-occupied & 36.0 & 55.9 & 4.4 & 3.7 & 91.9 & 8.1 \\
\hline Multifamily...$\ldots \ldots$ & 59.3 & 38.2 & 1.2 & 1.3 & 97.5 & 2.5 \\
\hline
\end{tabular}

Note. Analysis is restricted to institutions that were examined in the past five years under the large-institution CRA exam, that were in existence for at least one year, that received an "outstanding" or "satisfactory" rating on the exam, and that had assets of more than $\$ 250$ million in 2003. Data exclude strategic-plan, wholesale, and limited-purpose institutions (see table 1, note 7)

remote areas and extended 18.0 percent of their home-purchase loans, 20.6 percent of their homeimprovement loans, and 23.9 percent of their smallfarm or small-business loans in such areas. ${ }^{29}$

The data for exurban areas are more difficult to interpret than are the data for remote areas. Generally, urban-rural institutions make more retail loans per family in exurban areas than in urban areas (data derived from table 10). But such institutions extend

29. In two size classes (the largest and the smallest), remote areas received fewer multifamily loans as measured against the distribution of families than did other areas. However, in both cases, remote areas received more multifamily loans as measured against multifamily housing structures, arguably a better measure of comparison. and institutions with headquarters in US.-affiliated areas. Data also exclude census tracts in U.S.-affiliated areas. For definition of assessment area, see table 9 , note 1

1. Offices consist of headquarters and branches.

fewer retail loan dollars per deposit dollar in exurban areas than in urban areas (data derived from table 11). This apparent inconsistency may be explained by the fact that the majority of the urban-rural institutions in our sample, particularly the smaller ones, have headquarters in exurban areas. The deposit data may reflect a practice by some of those institutions of booking deposits to their headquarters regardless of the locale from which deposits originated.

The tendency of urban-rural institutions to make more retail loans to their rural components than to their urban components also holds true at the level of the individual institution. With one exception, more than one-half of the institutions in every size category 
11. Retail loan amounts and deposits in the assessment areas of large banking institutions with urban and rural branches, grouped by asset size of institution and distributed by location of assessment area, as of December 31, 2003

Percent

\begin{tabular}{|c|c|c|c|c|c|c|}
\hline \multirow{2}{*}{$\begin{array}{l}\text { Asset size of institution and } \\
\text { loan amounts and deposits }\end{array}$} & \multicolumn{2}{|c|}{ Ur: an } & \multicolumn{2}{|c|}{ Rural } & \multicolumn{2}{|c|}{ Total } \\
\hline & Center city & Suburban & Exurban & Remote & Urban & Rural \\
\hline \multicolumn{7}{|l|}{$\$ 250$ million to $\$ 500$ million } \\
\hline Home-purchase ......... & 24.9 & 34.4 & 24.8 & 16.0 & 59.2 & 40.8 \\
\hline Home-improvement $\quad \ldots \ldots \ldots \ldots \ldots \ldots \ldots \ldots \ldots \ldots \ldots$ & 12.1 & 40.6 & 33.0 & 14.2 & 52.7 & 47.3 \\
\hline Small-business or small-farm $\ldots \ldots \ldots \ldots \ldots \ldots$ & 19.4 & 26.0 & 27.0 & 27.6 & 45.3 & 54.7 \\
\hline 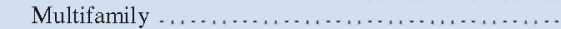 & 38.0 & 32.9 & 23.9 & 5.2 & 71.0 & 29.0 \\
\hline 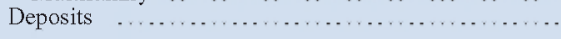 & 20.1 & 23.7 & 40.3 & 15.9 & 43.8 & 56.2 \\
\hline \multicolumn{7}{|l|}{$\$ 500$ million to $\$ 1$ billion } \\
\hline \multicolumn{7}{|l|}{ Loans } \\
\hline Home-purchase ... & 27.2 & 36.0 & 18.8 & 18.0 & 63.2 & 36.8 \\
\hline Home-improvement $\ldots \ldots \ldots \ldots \ldots$ & 20.7 & 31.6 & 27.1 & 20.6 & 52.3 & 47.7 \\
\hline Small-business or small-farm $\ldots \ldots \ldots \ldots \ldots \ldots$ & 26.6 & 25.7 & 23.7 & 23.9 & 52.3 & 47.6 \\
\hline 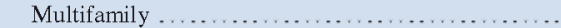 & 58.9 & 20.5 & 9.8 & 10.7 & 79.4 & 20.5 \\
\hline 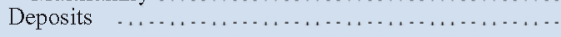 & 29.8 & 29.1 & 27.5 & 13.6 & 58.9 & 41.1 \\
\hline \multicolumn{7}{|l|}{$\$ 1$ billion to $\$ 5$ billion } \\
\hline Loans & & & & & & \\
\hline Home-purchase ..... & 34.9 & 43.3 & 12.0 & 9.7 & 78.2 & 21.7 \\
\hline Home-improvement $\ldots \ldots \ldots \ldots \ldots \ldots \ldots \ldots \ldots$ & 24.5 & 43.5 & 19.2 & 12.8 & 68.0 & 32.0 \\
\hline Small-business or small-farm $\ldots \ldots \ldots \ldots \ldots \ldots \ldots$ & 40.0 & 32.2 & 14.3 & 13.6 & 72.2 & 27.9 \\
\hline Multifamily $\ldots \ldots \ldots \ldots$ & 57.8 & 29.4 & 6.0 & 6.8 & 87.2 & 12.8 \\
\hline 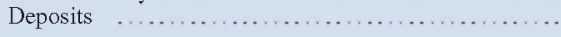 & 43.3 & 29.3 & 18.8 & 8.5 & 72.6 & 27.3 \\
\hline \multicolumn{7}{|l|}{ More than $\$ 5$ billion } \\
\hline Loans & & & & & & \\
\hline Home-purchase ... & 36.5 & 57.1 & 2.9 & 3.4 & 93.6 & 6.4 \\
\hline Home-improvement $\ldots \ldots \ldots \ldots \ldots \ldots \ldots \ldots \ldots \ldots \ldots \ldots$ & 27.1 & 61.1 & 6.2 & 5.5 & 88.2 & 11.7 \\
\hline Small-business or small-farm $\ldots \ldots \ldots \ldots \ldots \ldots \ldots$ & 41.7 & 43.6 & 7.4 & 7.2 & 85.3 & 14.6 \\
\hline 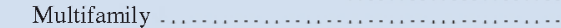 & 59.8 & 37.2 & 1.3 & 1.7 & 97.0 & 3.0 \\
\hline 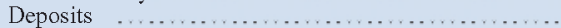 & 59.8 & 32.7 & 5.2 & 2.3 & 92.5 & 7.5 \\
\hline
\end{tabular}

NotE. See general note to table 10 .

extended more retail loans per family, per owneroccupied housing structure, or per multifamily housing structure to the rural parts of their assessment areas than to the urban parts (table 12). The exception was multifamily loans for institutions in the smallest size category. When measured in terms of retail loan dollars per deposit dollar, the results were somewhat mixed. For example, the rural parts appeared to get more home-improvement loans but fewer homepurchase loans than did the urban parts. ${ }^{30}$

The second test compared rural institutions with similarly situated urban institutions in two respects: the likelihood of receiving an "outstanding" CRA rating and the level of engagement in community development lending. The sample in this test used the same size categories as the sample in the first test and was also restricted to institutions covered under the large-institution evaluation procedures. The second test, however, eliminated the requirement that an institution have both urban and rural parts in its assessment areas.

30. The calculations of retail loan dollars per deposit dollars tend to show higher lending to the urban part than do the calculations of retail loan numbers per population because retail loans in urban areas are generally larger than in rural areas, a reflection of higher property values.
The evidence suggests that rural banking institutions with assets of less than $\$ 1$ billion are not less likely to receive "outstanding" ratings than are urban institutions with assets of less than $\$ 1$ billion (table 13). Exurban institutions with assets between $\$ 250$ million and $\$ 500$ million are somewhat less likely to receive "outstanding" ratings than are their urban counterparts, but exurban institutions with assets between $\$ 500$ million and $\$ 1$ billion are significantly more likely to do so. Few institutions with assets exceeding $\$ 1$ billion have headquarters in rural areas; those in that category are less likely to receive "outstanding" CRA ratings than are institutions that have assets exceeding $\$ 1$ billion and headquarters in urban areas.

The evidence offers modest support for the conclusion that rural institutions do less community development lending than do similarly sized urban institutions. In each asset-size category under $\$ 5$ billion, the percentage of rural institutions that reported no community development lending in 2003 was comparable to the percentage of similarly sized urban institutions that did so (data derived from table 13). However, for every asset-size category, with one exception, rural institutions that reported community development lending for 2003 made a smaller dollar amount 
12. Proportion of large banking institutions with both urban and rural branches that overserve parts of their assessment areas in terms of either number of loans or loan amount, by asset size of institution, type of loan, and location of assessment area, as of December 31, 2003

Percent

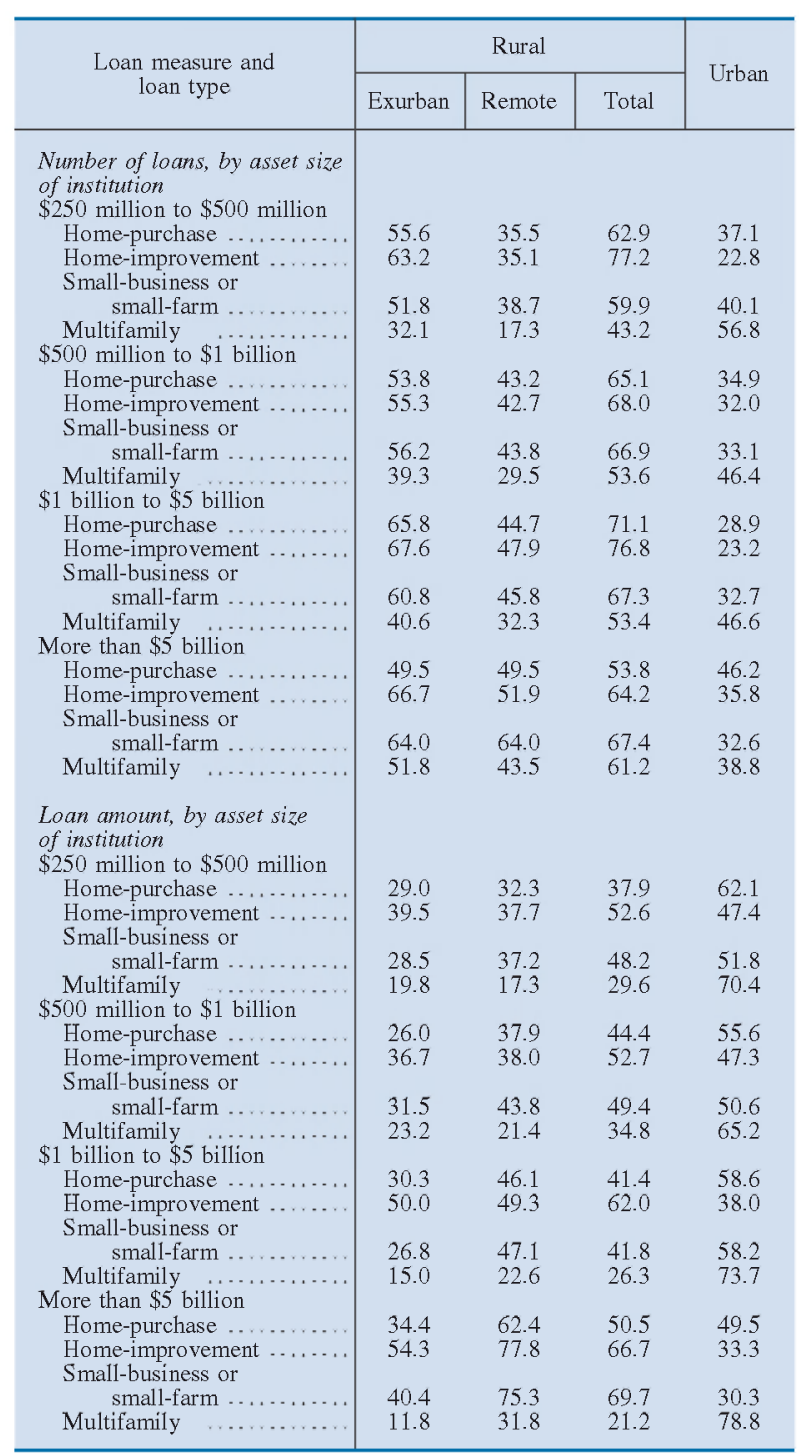

Note. See generál nóte tó táble 10 . Overserving by an institution in part of its assessment areas is measured by the ratio of the number of loans or the aggregate loan amount in that part to the number of owner-occupied housing structures (in the case of home-purchase and home-improvement loans), or to the number of families (in the case of small-business or small-farm loans), or to the number of multifamily housing structures (in the case of multifamily loans) in that part. An institution overserves in part of its assessment areas for a particular loan type if the ratio in the part, either for number of loans or loan amount, exceeds the average ratio for all the institution's assessment areas

of community development loans than did urban institutions. The exception was remote institutions with assets between $\$ 500$ million and $\$ 1$ billion. These institutions had higher community development loan dollar amounts than did the combination of same-sized center-city and suburban institutions.
13. Share of large banking institutions that received an "outstanding" rating on their most recent large-institution CRA exam and the extent of community development lending among large institutions, by asset size of institution and location of headquarters, as of December 31, 2003

\begin{tabular}{|c|c|c|c|c|}
\hline \multirow{2}{*}{$\begin{array}{l}\text { Characteristic and } \\
\text { asset size of institution }\end{array}$} & \multicolumn{2}{|c|}{ Urban } & \multicolumn{2}{|c|}{ Rural } \\
\hline & $\begin{array}{l}\text { Center } \\
\text { city }\end{array}$ & Suburban & Exurban & Remote \\
\hline \multirow{2}{*}{\multicolumn{5}{|c|}{$\begin{array}{l}\text { "Outstanding" rating } \\
\$ 250 \text { million to } \$ 500 \text { million }\end{array}$}} \\
\hline & & & & \\
\hline Number & 137 & 163 & 95 & 62 \\
\hline Percent & 8.0 & 9.8 & 6.3 & 14.5 \\
\hline \multicolumn{5}{|l|}{$\$ 500$ million to $\$ 1$ billion } \\
\hline Number.......... & 184 & 171 & 47 & 39 \\
\hline Percent $\quad \ldots \ldots \ldots$ & 13.0 & 13.5 & 29.8 & 15.4 \\
\hline \multicolumn{5}{|l|}{$\$ 1$ billion to $\$ 5$ billion } \\
\hline Number......... & 217 & 113 & 32 & 12 \\
\hline Percent $\quad . . . . . .$. & 29.0 & 28.3 & 3.1 & 16.2 \\
\hline \multicolumn{5}{|l|}{ More than $\$ 5$ billion } \\
\hline Number & 144 & 24 & 7 & 1 \\
\hline Percent $\ldots \ldots \ldots \ldots \ldots \ldots .$. & 52.1 & 45.8 & .0 & .0 \\
\hline \multicolumn{5}{|l|}{$\begin{array}{l}\text { Made community development } \\
\text { loans in } 20031\end{array}$} \\
\hline \multicolumn{5}{|l|}{$\$ 250$ million to $\$ 500$ million } \\
\hline Percent $\ldots \ldots \ldots \ldots \ldots \ldots$ & 63.0 & 53.8 & 56.3 & 53.8 \\
\hline $\begin{array}{c}\text { Average amount (thousands } \\
\text { of dollars) } \quad \ldots \ldots \ldots \ldots . .\end{array}$ & 3,833 & 3,164 & 2,074 & 1,346 \\
\hline \multicolumn{5}{|l|}{$\$ 500$ million to $\$ 1$ billion } \\
\hline Percent $\quad \ldots \ldots \ldots \ldots \ldots \ldots$ & 74.7 & 65.3 & 55.6 & 73.5 \\
\hline $\begin{array}{c}\text { Average amount (thousands } \\
\text { of dollars) } \quad \ldots \ldots \ldots \ldots . . .\end{array}$ & 7,321 & 5,117 & 2,363 & 7,009 \\
\hline \multicolumn{5}{|l|}{$\$ 1$ billion to $\$ 5$ billion } \\
\hline Percent...$\ldots \ldots \ldots \ldots$ & 84.0 & 74.5 & 68.0 & 72.7 \\
\hline $\begin{array}{l}\text { Average amount (thousands } \\
\text { of dollars) }\end{array}$ & 24,073 & 22,106 & 9,070 & 13,338 \\
\hline \multicolumn{5}{|l|}{ More than $\$ 5$ billion } \\
\hline Percent $\quad \ldots \ldots \ldots \ldots \ldots$ & 90.8 & 84.2 & 100.0 & 100.0 \\
\hline $\begin{array}{l}\text { Average amount (thousands } \\
\text { of dollars) } \quad \ldots \ldots \ldots \ldots . .\end{array}$ & 291,814 & 188,318 & 19,945 & 6,716 \\
\hline
\end{tabular}

NotE. See general note to table 10 .

1. Average amount of loans was among institutions with such lending

This evidence on community development lending, however, is indirect and inconclusive. For example, it excludes any measure of community development investments or services. Moreover, because we lack information about the location of community development loans, inferences drawn from locations of institutions' headquarters are subject to dispute.

In sum, the retail lending and branching measures used here provide little evidence that banking institutions collectively or individually underserve rural areas, with the possible exception of community development lending. Moreover, there is no evidence that a lower percentage of rural-based institutions receive "outstanding" CRA performance ratings (at least for such institutions with less than $\$ 1$ billion in assets).

\section{Rural Areas That Would Be Affected by the Agencies' Proposed Options}

The agencies sought comment on several alternative definitions of CRA-eligible rural census tracts. Each 
alternative satisfies five basic principles. First, each alternative would permit an institution to know, when it decided to make a loan or investment, whether or not the loan or investment would qualify as community development. Second, each alternative would rely on measures that change no more often than annually and in most cases change much less frequently than that. Third, each alternative would rely on purely objective statistical criteria that could be applied mechanically and without judgment. Fourth, each alternative would be easy to apply: Any required calculations would be straightforward or would be obviated by the government's publication of a list of eligible areas. Fifth, each alternative would rely on readily available, governmentproduced data.

The three alternatives that we considered were (1) moving the income threshold for CRA-eligible rural tracts from 80 percent to 90 percent or 100 percent of the statewide nonmetropolitan median family income, (2) changing the baseline for determining the CRA eligibility of rural tracts from the statewide nonmetropolitan median family income to the statewide median family income, and (3) adopting a modified version of the criteria used by the Community Development Financial Institutions Fund (CDFI Fund) to identify "investment areas."

The fund uses four alternative criteria of interest here to classify geographic areas (tracts, counties, or other aggregations) as investment areas. According to the fund, an area qualifies as an investment area if it has (1) a median family income that is less than 80 percent of the relevant metropolitan median family income or the national metropolitan median family income, whichever is higher, in the case of a metropolitan area, or a median family income that is less than 80 percent of the relevant statewide nonmetropolitan median family income or the national nonmetropolitan median family income, whichever is higher, in the case of a nonmetropolitan area; (2) an unemployment rate of at least 1.5 times the national average; (3) a poverty rate of 20 percent or more; (4) a population loss of 10 percent or more between the previous and most recent censuses or a net migration loss of 5 percent or more over the five-year period preceding the most recent census. ${ }^{31}$ Data for unemployment, poverty, and population are updated

31. Community Development Financial Institutions Fund, U.S. Department of the Treasury (2004), "Community Development Financial Institutions Program," Federal Register, vol. 69 (May 11), p. 26259. The fund's definition of an investment area contains an additional criterion, which states that the area has "significant unmet needs for loans, equity investments, or financial services." We disregarded this criterion because the fund refrained from defining it in objective, quantitative terms. annually at the county level and decennially at the tract level.

To permit comparison with the current rule, we modified the fund's criteria. Instead of using the fund's income criterion, we used the CRA's. That is, we treated as CRA-eligible any tracts currently classified as lower income (using, in rural areas, the current CRA baseline of the nonmetropolitan statewide median family income) and any tracts currently classified as middle income that are located in a county that meets any of criteria 2 through 4 . Thus, in this article, when we refer to the "modified CDFI Fund criteria," we use a modification of the first fund criterion, the one based on income.

There are two key differences between the fund's criteria, which use non-income measures of community need, and the other alternatives, each of which relies solely on a relative tract-income criterion. First, the fund's criteria use measures for which data are at the county level, not the tract level. Second, the fund's county-level criteria use measures that are updated annually; income data at the tract level, in contrast, are updated only every ten years. ${ }^{32}$ Consequently, the way in which the fund's criteria identify CRA-eligible areas is different from that in which the income-based alternatives do, and the difference can result in different outcomes.

Our analysis expands on the agencies' proposal in two main respects. The agencies proposed to apply the alternatives outlined earlier only to rural areas and only for the purpose of qualifying activities as community development. Our analysis evaluates the alternatives on those terms but goes beyond those terms. In particular, we show the implications of adopting these alternatives in urban areas, divided into central-city and suburban components, and in rural areas, divided into exurban and remote components. We also show the implications of adopting the alternatives for the purpose of evaluating other CRArelated activities, such as retail lending (table 14).

We computed the effects of the alternatives on the coverage of rural and urban census tracts and on the retail lending activities that would have counted as CRA-related if the alternatives had been in effect in 2003 (we assumed that banking institutions had not altered their behavior). We compared each alternative with actual 2003 retail lending activities adjusted for changes, implemented in 2004, in the definitions and boundaries of metropolitan statistical areas. ${ }^{33}$

32. The two population criteria that we use in our adaptation of the fund's criteria are based on 2000 census data.

33. Institutions that filed 2003 HMDA and CRA small-business data used census tract definitions based on the 2000 census. Metropolitan area boundaries based on the 2000 census were not implemented 
14. Comparison of effects, on census tracts and on counties, of options for defining census tracts as CRA-eligible, by location of tract, as of December 31, 2003

Percent

\begin{tabular}{|c|c|c|c|c|c|c|c|}
\hline \multirow{2}{*}{ Item } & \multicolumn{2}{|c|}{ Urban } & \multicolumn{2}{|c|}{ Rural } & \multicolumn{3}{|c|}{ Total } \\
\hline & Center city & Suburban & Exurban & Remote & Urban & Rural & All \\
\hline \multicolumn{8}{|l|}{ Current rule } \\
\hline \multicolumn{8}{|l|}{ Less than 80 percent of MSA or non-MSA median ${ }^{1}$} \\
\hline CRA-eligible tracts $\quad \ldots \ldots \ldots \ldots \ldots \ldots \ldots \ldots \ldots \ldots \ldots \ldots$ & 43.5 & 18.6 & 12.6 & 17.9 & 31.1 & 14.6 & 28.0 \\
\hline $\begin{array}{l}\text { Population } \\
\text { Loans }\end{array}$ & 39.7 & 17.2 & 11.1 & 15.6 & 27.7 & 12.6 & 25.1 \\
\hline Small-business or small-farm $\quad \ldots \ldots \ldots \ldots \ldots$ & 30.7 & 16.7 & 10.9 & 13.1 & 22.5 & 11.9 & 15.8 \\
\hline Home-purchase $\quad$....................... & 20.3 & 13.8 & 9.1 & 12.7 & 16.8 & 10.7 & 12.9 \\
\hline Multifamily $\quad \ldots \ldots \ldots \ldots \ldots \ldots \ldots \ldots \ldots \ldots$ & 43.2 & 23.0 & 14.9 & 13.3 & 33.5 & 14.3 & 25.5 \\
\hline 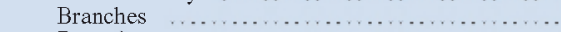 & 33.1 & 20.6 & 13.8 & 15.7 & 25.8 & 14.7 & 18.6 \\
\hline Deposits $\quad \ldots \ldots \ldots \ldots \ldots \ldots \ldots \ldots \ldots \ldots \ldots \ldots \ldots \ldots \ldots \ldots$ & 38.9 & 22.1 & 15.2 & 16.7 & 30.0 & 15.9 & 20.9 \\
\hline Counties without CRA-eligible tracts .............. & 12.0 & 31.9 & 56.9 & 61.3 & 18.0 & 59.0 & 44.8 \\
\hline Counties with only CRA-eligible tracts ............. & .6 & 2.8 & 1.7 & 4.8 & 2.4 & 3.2 & 2.9 \\
\hline \multicolumn{8}{|l|}{ Options } \\
\hline \multicolumn{8}{|l|}{ Less than 90 percent of MSA or non-MSA median ${ }^{1}$} \\
\hline 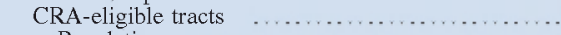 & 53.5 & 31.5 & 27.8 & 37.8 & 42.5 & 31.6 & 40.4 \\
\hline $\begin{array}{l}\text { Population } \\
\text { Loans }\end{array}$ & 50.1 & 29.7 & 25.4 & 34.3 & 39.3 & 28.5 & 37.4 \\
\hline Small-business or small-farm $\ldots \ldots \ldots \ldots \ldots$ & 41.2 & 33.5 & 27.4 & 36.4 & 38.7 & 31.6 & 34.2 \\
\hline Home-purchase...$\ldots \ldots \ldots \ldots \ldots \ldots \ldots$. & 30.2 & 30.4 & 25.2 & 34.7 & 33.0 & 29.5 & 30.7 \\
\hline 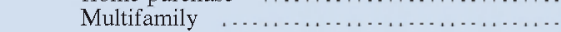 & 54.7 & 39.6 & 28.2 & 30.7 & 48.0 & 29.1 & 40.1 \\
\hline Branches ....... & 43.9 & 39.7 & 32.3 & 40.8 & 43.9 & 36.4 & 39.0 \\
\hline 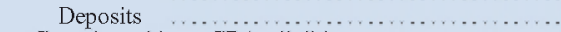 & 50.0 & 41.5 & 33.7 & 41.6 & 48.3 & 37.5 & 41.3 \\
\hline Counties without CRA-eligible tracts .............. & 8.5 & 13.2 & 29.5 & 31.3 & 5.9 & 30.4 & 21.9 \\
\hline Counties with only CRA-eligible tracts $\ldots . . . \ldots \ldots$ & 1.9 & 9.7 & 6.8 & 18.3 & 8.5 & 12.4 & 11.1 \\
\hline \multicolumn{8}{|l|}{ Less than 100 percent of MSA or non-MSA median ${ }^{1}$} \\
\hline 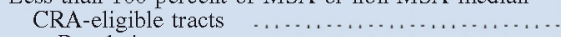 & 63.0 & 47.0 & 51.0 & 62.3 & 55.0 & 55.3 & 55.1 \\
\hline 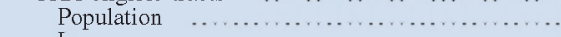 & 60.0 & 45.2 & 48.1 & 57.7 & 52.1 & 51.4 & 52.0 \\
\hline $\begin{array}{l}\text { Loans } \\
\text { Small-business or small-farm }\end{array}$ & 525 & 542 & 528 & 658 & & 588 & 581 \\
\hline $\begin{array}{l}\text { small-business or small-tarm } \ldots \ldots \ldots \ldots \ldots \ldots \\
\text { Home-purchase }\end{array}$ & $\begin{array}{r}52.3 \\
42.4\end{array}$ & $\begin{array}{l}54.2 \\
49.8\end{array}$ & $\begin{array}{l}52.8 \\
50.7\end{array}$ & $\begin{array}{l}65.8 \\
62.4\end{array}$ & $\begin{array}{l}56.7 \\
50 ?\end{array}$ & 58.8 & 58.1 \\
\hline Multifamily $\quad \ldots \ldots \ldots \ldots \ldots \ldots \ldots \ldots \ldots \ldots \ldots \ldots$ & 65.9 & 58.9 & $\begin{array}{l}50.7 \\
49.7\end{array}$ & $\begin{array}{l}62.4 \\
53.8\end{array}$ & $\begin{array}{l}50.2 \\
630\end{array}$ & 56.1 & 54.0 \\
\hline 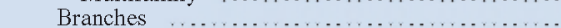 & 56.1 & 59.7 & 583 & & 63.9 & 51.2 & 58.6 \\
\hline Deposits & 60.1 & 600 & 38.5 & 69.4 & 61.7 & 63.6 & 63.0 \\
\hline Counties without CRA-eljgible tracts & 60.7 & 60.9 & 59.7 & 69.8 & 64.9 & 64.6 & 64.7 \\
\hline Counties without CRA-eligible tracts .............. & 5.8 & 3.2 & 10.0 & 10.3 & 1.3 & 10.1 & 7.1 \\
\hline Counties with only CRA-eligible tracts $\ldots \ldots \ldots \ldots \ldots$ & 4.1 & 20.4 & 21.3 & 42.3 & 17.1 & 31.5 & 26.5 \\
\hline \multicolumn{8}{|l|}{ Less than 80 percent of state median ${ }^{2}$} \\
\hline CRA-eligible tracts $\quad \ldots \ldots \ldots \ldots \ldots \ldots \ldots \ldots \ldots \ldots \ldots \ldots \ldots \ldots$ & 41.6 & 17.5 & 39.8 & 48.2 & 29.5 & 43.0 & 32.1 \\
\hline 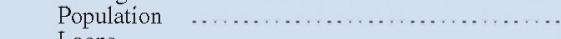 & 37.8 & 15.9 & 37.5 & 44.6 & 26.2 & 40.0 & 28.6 \\
\hline Loans & & & & & & & \\
\hline Small-business or small-farm $\quad \ldots \ldots \ldots \ldots \ldots$ & 32.4 & 15.9 & 40.0 & 46.9 & 21.4 & 43.2 & 35.2 \\
\hline 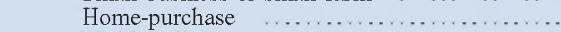 & 22.0 & 13.8 & 38.3 & 45.5 & 16.4 & 41.6 & 32.8 \\
\hline Multifamily $\ldots \ldots \ldots \ldots \ldots \ldots \ldots \ldots \ldots \ldots \ldots \ldots \ldots \ldots \ldots$ & 44.1 & 21.4 & 38.3 & 37.6 & 32.3 & 38.0 & 34.7 \\
\hline 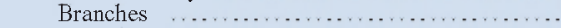 & 34.6 & 19.6 & 46.2 & 51.8 & 24.8 & 48.9 & 40.5 \\
\hline 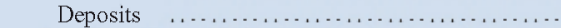 & 40.4 & 20.9 & 47.3 & 52.4 & 28.7 & 49.8 & 42.4 \\
\hline Counties without CRA-eligible tracts ............. & 12.2 & 37.4 & 18.7 & 24.4 & 23.2 & 21.5 & 22.1 \\
\hline Counties with only CRA-eligible tracts $\ldots \ldots \ldots \ldots \ldots$ & 1.2 & 3.2 & 15.3 & 28.2 & 2.8 & 21.6 & 15.0 \\
\hline \multicolumn{8}{|l|}{ Modified CDFI Fund criteria ${ }^{3}$} \\
\hline \multicolumn{8}{|l|}{ Combined } \\
\hline CRA-eligible tracts $\ldots \ldots \ldots \ldots \ldots \ldots \ldots \ldots \ldots \ldots \ldots \ldots$ & 49.1 & 22.9 & 29.6 & 38.1 & 36.0 & 32.8 & 35.4 \\
\hline 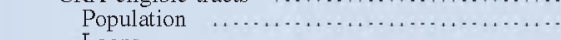 & 45.1 & 21.5 & 27.9 & 34.5 & 32.6 & 30.2 & 32.1 \\
\hline Loans & & & & & & & \\
\hline Small-business or small-farm $\ldots \ldots \ldots \ldots \ldots$ & 36.4 & 22.5 & 31.1 & 38.6 & 28.0 & 34.6 & 32.2 \\
\hline Home-purchase $\quad \ldots \ldots \ldots \ldots \ldots \ldots \ldots \ldots \ldots$ & 26.6 & 20.3 & 30.3 & 36.1 & 23.3 & 33.0 & 29.6 \\
\hline Multifamily $\ldots \ldots \ldots \ldots \ldots \ldots \ldots \ldots \ldots \ldots$ & 49.0 & 28.8 & 29.1 & 31.3 & 39.1 & 29.9 & 35.3 \\
\hline 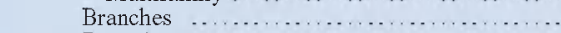 & 38.9 & 26.5 & 33.9 & 41.3 & 31.6 & 37.5 & 35.4 \\
\hline Deposits $\quad \ldots \ldots \ldots \ldots \ldots \ldots \ldots \ldots \ldots \ldots \ldots \ldots \ldots \ldots \ldots \ldots$ & 44.2 & 27.9 & 34.9 & 42.1 & 35.4 & 38.3 & 37.3 \\
\hline Counties without CRA-eligible tracts $\ldots \ldots \ldots \ldots$ & 11.2 & 29.6 & 45.9 & 44.1 & 16.9 & 45.1 & 35.3 \\
\hline Counties with only CRA-eligible tracts $\ldots . . . .$. & 1.6 & 7.8 & 24.3 & 33.7 & 6.8 & 28.9 & 21.2 \\
\hline
\end{tabular}

Each of the proposals would substantially increase the number of rural tracts that are CRA-eligible- that is. eligible for area-based communily development activities. Currently. 14.6 percent of rural census

for filings related to HMDA and the CRA until 2004. In constructing the numbers we report here, we use the 2004 definitions of metropolitan statistical areas. tracts are classilied as CRA-eligible; these tracts contain 12.6 percent of the rural population. Raising the threshold to 90 percent for rural areas would roughly equate the percentages of urban and rural tracts classilied as CRA-eligible, al about 31 percent: raising the threshold to 100 percent would qualify 55 percent of rural tracts as CRA-eligible. Similarly, changing the baseline for classifying rural tracts to the state- 


\begin{tabular}{|c|c|c|c|c|c|c|c|}
\hline \multirow{2}{*}{ Item } & \multicolumn{2}{|c|}{ Urban } & \multicolumn{2}{|c|}{ Rural } & \multicolumn{3}{|c|}{ Total } \\
\hline & Center city & Suburban & Exurban & Remote & Urban & Rural & All \\
\hline \multicolumn{8}{|l|}{$\begin{array}{l}\text { Modified CDFI Fund criteria icontinuedi } \\
\text { Unemployment }\end{array}$} \\
\hline CRA-eligible tracts $\ldots \ldots \ldots \ldots$ & 46.0 & 20.5 & 23.7 & 26.8 & 33.3 & 24.9 & 31.7 \\
\hline Population ...... & 42.1 & 19.1 & 22.4 & 24.3 & 29.9 & 23.1 & 28.7 \\
\hline \multicolumn{8}{|l|}{ Loans } \\
\hline Small-business or small-farm & 33.2 & 20.0 & 23.7 & 22.8 & 25.5 & 23.3 & 24.1 \\
\hline Home-purchase ............ & 22.9 & 17.6 & 22.2 & 23.4 & 20.4 & 22.8 & 21.9 \\
\hline Multifamily ......... & 45.7 & 26.4 & 24.5 & 21.9 & 36.6 & 23.6 & 31.1 \\
\hline Branches ..... & 35.3 & 23.9 & 26.4 & 25.1 & 28.7 & 25.8 & 26.8 \\
\hline Deposits $\quad \ldots \ldots \ldots \ldots \ldots \ldots \ldots$ & 40.8 & 25.3 & 27.6 & 25.9 & 32.7 & 26.8 & 28.9 \\
\hline Counties without CRA-eligible tracts .. & 11.6 & 30.6 & 49.3 & 55.9 & 17.3 & 52.5 & 40.3 \\
\hline Counties with only CRA-eligible tracts .. & 1.2 & 5.7 & 14.7 & 16.3 & 5.1 & 15.5 & 11.8 \\
\hline \multicolumn{8}{|l|}{ Poverty } \\
\hline CRA-eligible tracts & 45.5 & 19.1 & 19.0 & 25.8 & 32.3 & 21.6 & 30.3 \\
\hline Population ..... & 41.5 & 17.7 & 17.3 & 23.7 & 28.9 & 19.5 & 27.2 \\
\hline \multicolumn{8}{|l|}{ Loans } \\
\hline Small-business or small-farm & 31.6 & 17.7 & 18.0 & 22.4 & 23.5 & 20.1 & 21.3 \\
\hline Home-purchase $. . . \ldots \ldots . .$. . & 21.2 & 15.1 & 17.1 & 21.6 & 18.1 & 19.2 & 18.8 \\
\hline Multifamily ...... & 44.3 & 23.6 & 19.8 & 19.7 & 34.3 & 19.8 & 28.2 \\
\hline Branches $\ldots \ldots \ldots \ldots \ldots \ldots \ldots \ldots$ & 33.7 & 21.7 & 20.9 & 25.1 & 26.9 & 22.9 & 24.3 \\
\hline Deposits $\ldots \ldots \ldots \ldots \ldots$ & 39.4 & 23.2 & 22.1 & 25.9 & 31.0 & 23.9 & 26.4 \\
\hline Counties without CRA-eligible tracts ... & 12.0 & 31.5 & 54.9 & 57.0 & 17.8 & 55.9 & 42.7 \\
\hline Counties with only CRA-eligible tracts.... & .6 & 4.4 & 12.3 & 17.6 & 3.9 & 14.9 & 11.1 \\
\hline \multicolumn{8}{|l|}{ Population loss } \\
\hline CRA-eligible tracts & 47.8 & 21.0 & 15.2 & 25.7 & 34.4 & 19.2 & 31.5 \\
\hline Population $\ldots . .$. & 43.5 & 19.4 & 13.3 & 22.0 & 30.7 & 16.3 & 28.2 \\
\hline \multicolumn{8}{|l|}{ Loans } \\
\hline Small-business or small-farm & 33.9 & 18.8 & 14.5 & 24.9 & 24.7 & 19.4 & 21.3 \\
\hline Home-purchase …......... & 24.1 & 16.0 & 12.9 & 22.3 & 19.3 & 17.2 & 17.9 \\
\hline Multifamily $\ldots \ldots \ldots \ldots \ldots \ldots$ & 46.2 & 25.1 & 16.5 & 20.5 & 35.9 & 18.0 & 28.4 \\
\hline Branches ....... & 36.7 & 22.7 & 17.8 & 28.3 & 28.2 & 22.9 & 24.7 \\
\hline Deposits $\ldots \ldots \ldots \ldots \ldots \ldots$ & 42.3 & 24.2 & 19.1 & 29.2 & 32.3 & 24.0 & 26.9 \\
\hline Counties without CRA-eligible tracts ... & 11.6 & 31.1 & 54.1 & 51.2 & 17.8 & 52.7 & 40.6 \\
\hline Counties with only CRA-eligible tracts & 1.0 & 3.9 & 5.7 & 17.8 & 3.1 & 11.6 & 8.6 \\
\hline \multicolumn{8}{|l|}{ Meмo } \\
\hline Number of tracts & 26,278 & 26,298 & 7,661 & 4,650 & 52,576 & 12,311 & 64,887 \\
\hline
\end{tabular}

NotE. See general note to table 9, and for description of lending and branch data reported in 2003 geographies, see related description for assessment areas in table 9, note 1. Analysis is restricted to lending done within assessment areas and excludes institutions not covered by the CRA.

1. Median family income in census tract as a percentage of the median family income in the metropolitan statistical area (MSA) or nonmetropolitan portion of the state (non-MSA) in which the census tract is located.

wide median but retaining the 80 percent thresholdwould qualify 43 percent of rural tracts as CRAeligible. ${ }^{34}$

We also calculated the effects of adopting the modified CDFI Fund criteria. Using the criteria to identify middle-income tracts that would be CRAeligible would classify 33 percent of rural census tracts as lower income, a proportion nearly equal to the 31 percent of urban census tracts currently classified as CRA-eligible (see "Current rule" and "Modified CDFI Fund criteria" categories). When each of the unemployment, poverty, and population loss criteria is applied separately, the proportion of rural tracts classified as CRA-eligible is 25 percent, 22 per-

34. Rhode Island is the only state in which the nonmetropolitan area median income is higher than the overall state median income.
2. Median family income in census tract as a percentage of the median family income in the state in which the census tract is located.

3. For description of modification to CDFI Fund criteria, see text.

CDFI Fund Community Development Financial Institutions Fund.

cent, and 19 percent respectively. Applying the modified CDFI Fund criteria to urban tracts would have a comparatively modest effect, increasing the number of urban tracts classified as CRA-eligible from 31 percent to 36 percent. The general patterns described in this paragraph and in the previous one are also found when the unit of analysis is the proportion of population in CRA-eligible tracts.

We also profiled the economic and demographic characteristics of the tracts now classified as lower income and of the additional tracts that would be CRA-eligible under each of the alternatives (table 15). The profile reveals that, in rural areas, the exurban and remole tracts currenty classilied as lower income have similar average characteristics along most dimensions (although the number of tracts in exurban and remote areas is different). In urban 
15. Characteristics of CRA-eligible census tracts and counties and of those that would be added under options for defining census tracts as CRA-eligible, by location of tract, as of December 31, 2003

Percent except as noted

\begin{tabular}{|c|c|c|c|c|c|c|c|}
\hline \multirow{2}{*}{ Item } & \multicolumn{2}{|c|}{ Ur: an } & \multicolumn{2}{|c|}{ Rural } & \multicolumn{3}{|c|}{ Total } \\
\hline & $\begin{array}{c}\text { Center } \\
\text { city }\end{array}$ & Suburban & Exurban & Remote & Urban & Rural & All \\
\hline \multirow{2}{*}{\multicolumn{8}{|c|}{$\begin{array}{l}\text { Current rule } \\
\text { Less than } 80 \text { percent of MSA or non-MSA median } 1\end{array}$}} \\
\hline & & & & & & & \\
\hline \multicolumn{8}{|l|}{$\begin{array}{l}\text { Less than } 80 \text { percent of MSA or non-MISA median }{ }^{-1} \\
\text { Tract (average characteristics) }\end{array}$} \\
\hline \multicolumn{8}{|l|}{ Share of families with income } \\
\hline Less than or equal to poverty level $\ldots \ldots \ldots \ldots \ldots \ldots$ & 23.9 & 15.6 & 22.9 & 23.1 & 21.4 & 23.0 & 21.6 \\
\hline Less than 50 percent of MSA or non-MSA median ${ }^{1} \ldots \ldots \ldots \ldots \ldots$ & 43.8 & 35.3 & 34.5 & 34.7 & 41.3 & 34.6 & 40.6 \\
\hline Between 50 percent and 80 percent of MSA or non-MSA median 1 & 22.7 & 24.8 & 22.2 & 22.6 & 23.3 & 22.4 & 23.2 \\
\hline 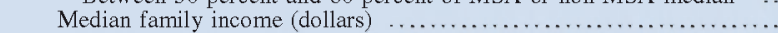 & 30,067 & 36,343 & 27,741 & 27,090 & 31,949 & 27,440 & 31,501 \\
\hline Median relative to MSA or non-MSA & 57.5 & 66.6 & 69.6 & 69.0 & 60.2 & 69.3 & 61.1 \\
\hline \multicolumn{8}{|l|}{ Housing } \\
\hline Median house value (dollars) & 98,973 & 94,019 & 53,528 & 51,056 & 97,480 & 52,389 & 92,969 \\
\hline Median house age (years) ......... & 30.6 & 33.1 & 33.9 & 35.1 & 31.4 & 34.5 & 31.7 \\
\hline Occupancy by owner .............. & 35.3 & 48.1 & 53.5 & 53.3 & 39.2 & 53.5 & 40.6 \\
\hline Vacancy rate 2 ....... & 9.8 & 9.2 & 15.6 & 18.4 & 9.7 & 16.9 & 10.4 \\
\hline \multicolumn{8}{|l|}{ Population } \\
\hline Over age 65 & 10.7 & 12.7 & 14.1 & 14.6 & 11.3 & 14.4 & 11.6 \\
\hline Minority ${ }^{3} \ldots \ldots \ldots \ldots \ldots$ & 66.7 & 45.9 & 40.8 & 33.4 & 60.4 & 37.4 & 58.1 \\
\hline \multicolumn{8}{|l|}{ County (average characteristics) } \\
\hline Population change, $1990-2000$ & 1.1 & 1.2 & 1.1 & 1.0 & 1.1 & 1.1 & 1.1 \\
\hline Net migration rate, $1995-994 \ldots \ldots \ldots \ldots$ & -1.3 & 2.4 & .8 & -9 & -.2 & .0 & -.2 \\
\hline 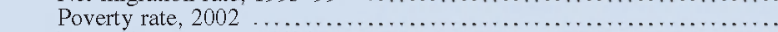 & 14.1 & 11.4 & 17.5 & 19.3 & 13.3 & 18.3 & 13.8 \\
\hline 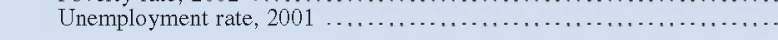 & 6.0 & 5.6 & 7.6 & 7.2 & 5.9 & 7.4 & 6.1 \\
\hline \multicolumn{8}{|l|}{ Options } \\
\hline Less than 90 percent of MSA median or non-MSA median ${ }^{1}$ & & & & & & & \\
\hline Tract (average characteristics) & & & & & & & \\
\hline Number added..$\ldots \ldots \ldots \ldots \ldots$ & 2,622 & 3,384 & 1,157 & 927 & 6,006 & 2,084 & 8,090 \\
\hline Share of families with income & & & & & & & \\
\hline Less than or equal to poverty level ............... & 10.0 & 8.2 & 13.7 & 13.3 & 9.0 & 13.5 & 10.2 \\
\hline Less than 50 percent of MSA or non-MSA median ${ }^{1} \ldots \ldots \ldots \ldots \ldots$ & 23.9 & 22.8 & 24.4 & 24.1 & 23.3 & 24.3 & 23.5 \\
\hline Between 50 percent and 80 percent of MSA or non-MSA median 1 & 21.9 & 22.9 & 21.4 & 21.9 & 22.4 & 21.6 & 22.2 \\
\hline 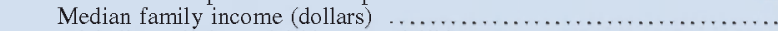 & 44,231 & 45,911 & 34,668 & 34,489 & 45,178 & 34,588 & 42,450 \\
\hline Median relative to MSA or non-MSA & 85.1 & 85.2 & 85.6 & 85.3 & 85.2 & 85.5 & 85.3 \\
\hline Housing & & & & & & & \\
\hline Median house value (dollars) ... & 121,304 & 103,360 & 64,487 & 59,496 & 111,172 & 62,269 & 98,569 \\
\hline 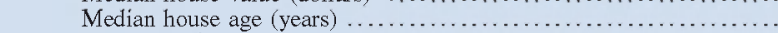 & 34.1 & 35.9 & 37.2 & 38.2 & 35.1 & 37.6 & 35.7 \\
\hline 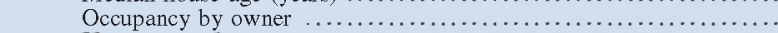 & 52.3 & 63.8 & 61.3 & 59.3 & 58.8 & 60.4 & 59.2 \\
\hline 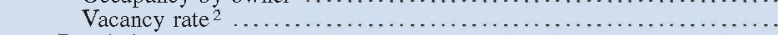 & 6.4 & 8.1 & 15.4 & 18.6 & 7.3 & 16.8 & 9.8 \\
\hline Population & & & & & & & \\
\hline Over age 65 & 13.0 & 14.0 & 15.8 & 16.7 & 13.6 & 16.2 & 14.2 \\
\hline Minority ${ }^{3}$................ & 40.5 & 24.7 & 19.7 & 15.6 & 31.6 & 17.9 & 28.1 \\
\hline County (average characteristics) & & & & & & & \\
\hline Population change, $1990-2000 \ldots$ & 1.1 & 1.2 & 1.1 & 1.0 & 1.1 & 1.1 & 1.1 \\
\hline 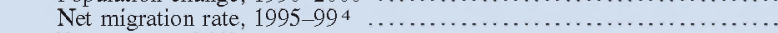 & .1 & 3.0 & 2.4 & .3 & 1.8 & 1.5 & 1.7 \\
\hline 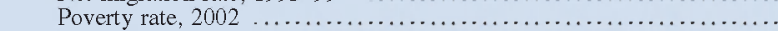 & 13.0 & 10.5 & 14.7 & 15.4 & 11.6 & 15.0 & 12.5 \\
\hline 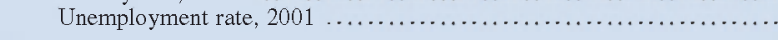 & 5.8 & 5.4 & 6.6 & 6.1 & 5.6 & 6.3 & 5.8 \\
\hline Less than 100 percent of MSA median or non-MSA median ${ }^{1}$ & & & & & & & \\
\hline Tract (average characteristics) & & & & & & & \\
\hline Number added ................ & 5,125 & 7,453 & 2,937 & 2,063 & 12,578 & 5,000 & 17,578 \\
\hline Share of families with income & & & & & & & \\
\hline Less than or equal to poverty level ............... & 9.0 & 7.1 & 11.9 & 11.7 & 7.9 & 11.8 & 9.0 \\
\hline Less than 50 percent of MSA or non-MSA median 1 .......... & 21.8 & 20.3 & 21.7 & 21.8 & 20.9 & $21 . \overline{7}$ & 21.1 \\
\hline Between 50 percent and 80 percent of MSA or non-MSA median ${ }^{1}$ & 20.9 & 21.6 & 20.4 & 20.8 & 21.3 & 20.6 & 21.1 \\
\hline 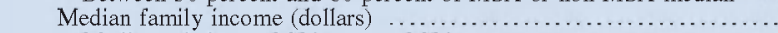 & 46,727 & 48,883 & 36,962 & 36,682 & 48,004 & 36,847 & 44,830 \\
\hline 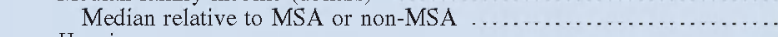 & 89.0 & 90.6 & 91.3 & 90.6 & 90.3 & 91.0 & 90.5 \\
\hline Housing & & & & & & & \\
\hline Median house value (dollars) ... & 125,857 & 110,561 & 68,236 & 64,522 & 116,781 & 66,704 & 102,523 \\
\hline 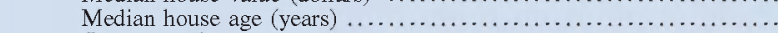 & 34.6 & 36.1 & 37.4 & 38.5 & 35.5 & 37.8 & 36.2 \\
\hline 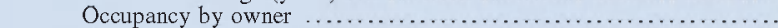 & 54.6 & 66.4 & 63.0 & 61.1 & 61.6 & 62.2 & $61 . \overline{8}$ \\
\hline 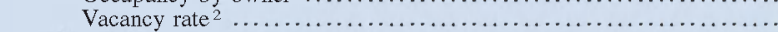 & 6.1 & 7.5 & 15.0 & 17.5 & 7.0 & 16.1 & 9.6 \\
\hline Population & & & & & & & \\
\hline Over age 65 & 13.2 & 13.7 & 15.7 & 16.8 & 13.5 & 16.1 & 14.3 \\
\hline Minority ${ }^{3} \ldots \ldots \ldots \ldots \ldots$ & 37.2 & 21.5 & 16.6 & 13.5 & 27.9 & 15.3 & 24.4 \\
\hline County (average characteristics) & & & & & & & \\
\hline Population change, $1990-2000$ & 1.1 & 1.2 & 1.1 & 1.0 & 1.1 & 1.1 & 1.1 \\
\hline 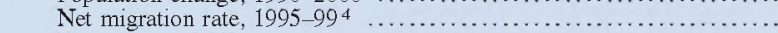 & .2 & 2.8 & 2.3 & .5 & 1.7 & 1.5 & 1.7 \\
\hline 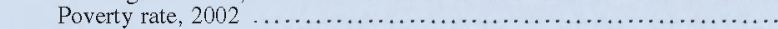 & 12.8 & 10.3 & 14.1 & 14.4 & 11.3 & 14.2 & 12.1 \\
\hline 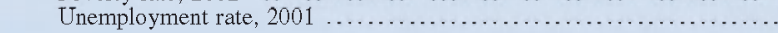 & 5.8 & 5.3 & 6.4 & 5.7 & 5.5 & 6.1 & 5.7 \\
\hline
\end{tabular}

See footnotes on page 228 .

areas, however, the center-city and suburban tracts with this classification are largely dissimilar. Further, a comparison of lower-income tracts in urban and rural areas reveals differences in most characteristics. The differences between suburban and exurban tracts are a case in point: Exurban tracts have higher pov- 
15.-Continued

Percent except as noted

\begin{tabular}{|c|c|c|c|c|c|c|c|}
\hline \multirow{2}{*}{ Item } & \multicolumn{2}{|c|}{ Urban } & \multicolumn{2}{|c|}{ Rural } & \multicolumn{3}{|c|}{ Total } \\
\hline & $\begin{array}{l}\text { Center } \\
\text { city }\end{array}$ & Suburban & Exurban & Remote & Urban & Rural & All \\
\hline \multicolumn{8}{|l|}{ Less than 80 percent of state median 5} \\
\hline \multicolumn{8}{|l|}{ Tract (average characteristics) } \\
\hline \multicolumn{8}{|l|}{ Share of families with income } \\
\hline Less than or equal to poverty level ............... & 14.2 & 11.8 & 12.7 & 12.4 & 12.9 & 12.6 & 12.7 \\
\hline Less than 50 percent of MSA or non-MSA median ${ }^{1} \ldots \ldots \ldots \ldots$ & 23.9 & 22.9 & 22.5 & 22.6 & 23.4 & 22.6 & 22.9 \\
\hline Between 50 percent and 80 percent of MSA or non-MSA median ${ }^{1}$ & 20.6 & 21.2 & 20.5 & 21.1 & 20.9 & 20.7 & 20.8 \\
\hline Median family income (dollars) $\ldots \ldots \ldots \ldots \ldots \ldots \ldots \ldots \ldots \ldots \ldots \ldots \ldots \ldots \ldots \ldots \ldots$ & 37,626 & 39,441 & 35,969 & 35,755 & 38,623 & 35,883 & 36,882 \\
\hline Median relative to MSA or non-MSA & 88.0 & 88.6 & 90.3 & 89.0 & 88.3 & 89.7 & 89.2 \\
\hline \multicolumn{8}{|l|}{ Housing } \\
\hline Median house value (dollars) & 98,707 & 92,916 & 66,651 & 62,111 & 95,517 & 64,821 & 76,000 \\
\hline Median house age (years) ...... & 32.9 & 35.5 & 37.4 & 38.2 & 34.3 & 37.7 & 36.5 \\
\hline Occupancy by owner ......... & 51.7 & 59.6 & 61.9 & 60.8 & 56.1 & 61.4 & 59.5 \\
\hline Vacancy rate ${ }^{2} \ldots \ldots \ldots \ldots$ & 7.6 & 9.9 & 15.7 & 18.1 & 8.8 & 16.6 & 13.8 \\
\hline \multicolumn{8}{|l|}{ Population } \\
\hline Over age 65 & 12.8 & 14.1 & 15.9 & 16.7 & 13.5 & 16.2 & 15.3 \\
\hline Minority $^{3} \ldots \ldots \ldots \ldots \ldots$ & 48.5 & 33.9 & 18.7 & 14.5 & 40.5 & 17.0 & 25.6 \\
\hline \multicolumn{8}{|l|}{ County (average characteristics) } \\
\hline Population change, $1990-2000$ & 1.1 & 1.1 & 1.1 & 1.1 & 1.1 & 1.1 & 1.1 \\
\hline Net migration rate, $1995-99^{4}$.. & -8 & .6 & 2.5 & .9 & .0 & 1.9 & 1.2 \\
\hline Poverty rate, $2002 \ldots \ldots \ldots \ldots \ldots$ & 16.6 & 14.0 & 14.6 & 15.0 & 15.2 & 14.7 & 14.9 \\
\hline Unemployment rate, 2001 ............. & 7.2 & 6.9 & 6.5 & 6.0 & 7.1 & 6.3 & 6.6 \\
\hline \multicolumn{8}{|l|}{ Modified CDFI Fund criteria ${ }^{6}$} \\
\hline Combined & & & & & & & \\
\hline Tract (average characteristics) & & & & & & & \\
\hline Number added ............. & 1,466 & 1,133 & 1,296 & 939 & 2,599 & 2,235 & 4,834 \\
\hline Share of families with income & & & & & & & \\
\hline Less than or equal to poverty level $\ldots \ldots \ldots \ldots \ldots$. & 10.8 & 9.2 & 13.6 & 13.3 & 10.1 & 13.5 & 11.7 \\
\hline Less than 50 percent of $\mathrm{MSA}$ or non-MSA median ${ }^{1} \ldots \ldots \ldots \ldots \ldots$ & 20.8 & 18.4 & 21.6 & 22.0 & 19.8 & 21.8 & 20.7 \\
\hline Between 50 percent and 80 percent of MSA or non-MSA median ${ }^{1}$ & 18.4 & 19.0 & 18.4 & 19.2 & 18.6 & 18.8 & 18.7 \\
\hline 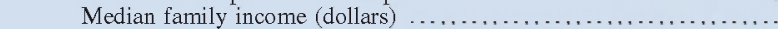 & 46,066 & 46,384 & 36,635 & 36,788 & 46,204 & 36,699 & 41,810 \\
\hline Median relative to MSA or non-MSA & 97.2 & 99.5 & 96.7 & 94.3 & 98.2 & 95.7 & 97.1 \\
\hline Housing & & & & & & & \\
\hline Median house value (dollars) & 125,820 & 107,152 & 66,391 & 62,328 & 117,679 & 64,686 & 93,151 \\
\hline 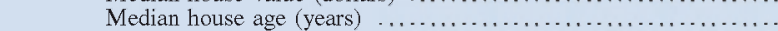 & 34.8 & 35.2 & 36.9 & 38.1 & 35.0 & 37.4 & 36.1 \\
\hline 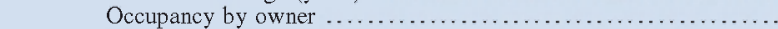 & 53.8 & 65.2 & 64.4 & 60.8 & 58.8 & 62.9 & 60.7 \\
\hline 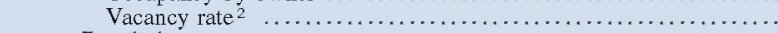 & 6.6 & 8.2 & 15.2 & 18.3 & 7.3 & 16.5 & 11.6 \\
\hline Population & & & & & & & \\
\hline Over age $65 \ldots \ldots$ & 13.7 & 13.0 & 14.7 & 15.9 & 13.4 & 15.2 & 14.3 \\
\hline Minority $^{3} \quad \ldots \ldots \ldots \ldots \ldots$ & 47.2 & 32.2 & 25.6 & 19.6 & 40.6 & 23.1 & 32.5 \\
\hline County (average characteristics) & & & & & & & \\
\hline Population change, $1990-2000 \ldots$ & 1.1 & 1.1 & 1.1 & 1.0 & 1.1 & 1.1 & 1.1 \\
\hline 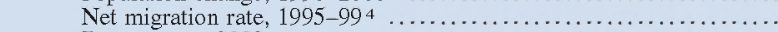 & -4.7 & -1.6 & .9 & -2.1 & -3.4 & -.3 & -2.0 \\
\hline 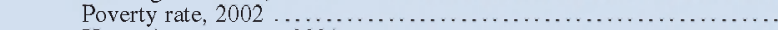 & 18.6 & 14.9 & 17.6 & 17.0 & 17.0 & 17.3 & 17.2 \\
\hline 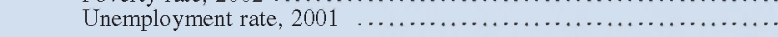 & 7.8 & 8.1 & 8.6 & 7.3 & 7.9 & 8.0 & 8.0 \\
\hline Unemployment & & & & & & & \\
\hline Tract (average characteristics) & & & & & & & \\
\hline Number added .............. & 653 & 502 & 848 & 412 & 1,155 & 1,260 & 2,415 \\
\hline Share of families with income & & & & & & & \\
\hline Less than or equal to poverty level $\ldots \ldots \ldots \ldots \ldots$ & 13.3 & 11.4 & 12.4 & 13.5 & 12.5 & 12.8 & 12.6 \\
\hline Less than 50 percent of MSA or non-MSA median ${ }^{1} \ldots \ldots \ldots \ldots$ & 21.8 & 19.8 & 21.0 & 22.3 & 20.9 & 21.5 & 21.2 \\
\hline Between 50 percent and 80 percent of MSA or non-MSA median ${ }^{1}$ & 17.5 & 19.0 & 18.7 & 19.4 & 18.1 & 18.9 & 18.6 \\
\hline Median family income (dollars) ............................ & 44,263 & 43,430 & 37.586 & 37.341 & 43,901 & 37.506 & 40,564 \\
\hline 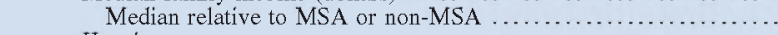 & 98.1 & 98.0 & 96.8 & 93.6 & 98.0 & 95.7 & 96.8 \\
\hline Housing & & & & & & & \\
\hline 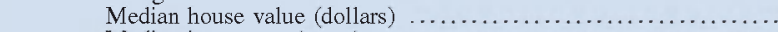 & 157,326 & 110,582 & 71,274 & 72,214 & 136,980 & 71,581 & 102,828 \\
\hline 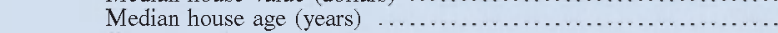 & 33.8 & 34.0 & 37.5 & 38.3 & 33.9 & 37.8 & 35.9 \\
\hline 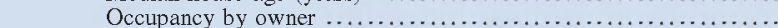 & 49.4 & 64.1 & 65.8 & 60.3 & 55.8 & 64.0 & 60.1 \\
\hline 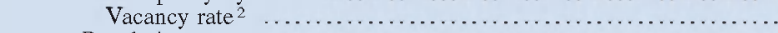 & 6.4 & 10.2 & 14.5 & 20.5 & 8.0 & 16.5 & 12.4 \\
\hline Population & & & & & & & \\
\hline 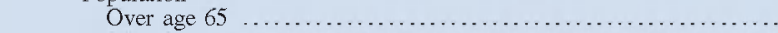 & 12.9 & 11.9 & 15.0 & 15.5 & 12.4 & 15.2 & 13.9 \\
\hline 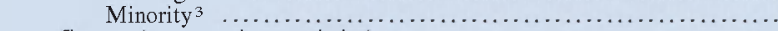 & 53.2 & 33.9 & 21.4 & 22.0 & 44.9 & 21.6 & 32.7 \\
\hline County (average characteristics) & & & & & & & \\
\hline 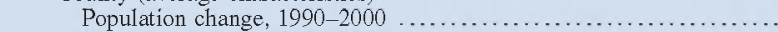 & 1.1 & 1.2 & 1.1 & 1.1 & 1.2 & 1.1 & 1.1 \\
\hline 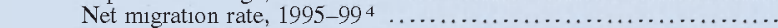 & -2.0 & 2.4 & 2.1 & .8 & -1 & 1.7 & .8 \\
\hline 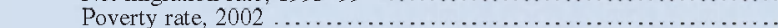 & 21.5 & 16.0 & 16.3 & 17.2 & 19.1 & 16.6 & 17.8 \\
\hline Unemployment rate, $2001 \quad \ldots \ldots \ldots \ldots \ldots \ldots \ldots \ldots$ & 9.9 & 10.8 & 10.0 & 10.2 & 10.3 & 10.0 & 10.2 \\
\hline
\end{tabular}

See footnotes on page 228 .

erty rates, vacancy rates, and unemployment rates and lower absolute incomes, house values, and population growth rates than do suburban tracts.
Nlthough the specific tracts added by each alternative are different, their economic and demographic characteristics are similar. Under any of the alterna- 
15.-Continued

Percent except as noted

\begin{tabular}{|c|c|c|c|c|c|c|c|}
\hline \multirow{2}{*}{ Item } & \multicolumn{2}{|c|}{ Urban } & \multicolumn{2}{|c|}{ Rural } & \multicolumn{3}{|c|}{ Total } \\
\hline & $\begin{array}{l}\text { Center } \\
\text { city }\end{array}$ & Suburban & Exurban & Remote & Urban & Rural & All \\
\hline \multicolumn{8}{|l|}{ Poverty } \\
\hline \multicolumn{8}{|l|}{ Tract (average characteristics) } \\
\hline Number added ................ & 521 & 131 & 485 & 368 & 652 & 853 & 1,505 \\
\hline \multicolumn{8}{|l|}{ Share of families with income } \\
\hline Less than or equal to poverty level $\ldots \ldots \ldots \ldots \ldots \ldots$ & 15.0 & 18.8 & 17.4 & 18.1 & 15.8 & 17.7 & 16.9 \\
\hline Less than 50 percent of MSA or non-MSA median ${ }^{1} \ldots \ldots \ldots \ldots \ldots$ & 23.1 & 22.6 & 24.1 & 24.9 & 23.0 & 24.4 & 23.8 \\
\hline Between 50 percent and 80 percent of MSA or non-MSA median 1 & 17.1 & 18.3 & 17.6 & 18.4 & 17.3 & 17.9 & 17.7 \\
\hline 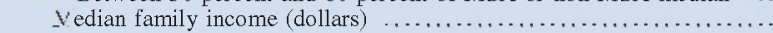 & 42,919 & 34,671 & 33,820 & 32,122 & 41,262 & 33,087 & 36,629 \\
\hline Median relative to MSA or non-MSA & 97.3 & 96.0 & 95.0 & 91.8 & 97.1 & 93.7 & 95.1 \\
\hline \multicolumn{8}{|l|}{ Housing } \\
\hline Median house value (dollars) & 165,803 & 74,434 & 56,220 & 51,471 & 147,360 & 54,172 & 94,491 \\
\hline Median house age (years) ...... & 33.7 & 31.2 & 35.9 & 36.5 & 33.2 & 36.2 & 34.9 \\
\hline Occupancy by owner ......... & 45.9 & 61.1 & 63.7 & 63.9 & 49.0 & 63.8 & 57.4 \\
\hline Vacancy rate ${ }^{2} \ldots \ldots \ldots \ldots$ & 6.7 & 11.9 & 16.0 & 15.5 & 7.7 & 15.8 & 12.3 \\
\hline \multicolumn{8}{|l|}{ Population } \\
\hline Over age 65 & 12.8 & 11.1 & 14.3 & 14.7 & 12.5 & 14.5 & 13.6 \\
\hline Minority ${ }^{3} \ldots \ldots \ldots \ldots \ldots$ & 60.9 & 59.1 & 37.7 & 28.7 & 60.6 & 33.8 & 45.4 \\
\hline \multicolumn{8}{|l|}{ County (average characteristics) } \\
\hline Population change, $1990-2000$ & 1.1 & 1.2 & 1.1 & 1.0 & 1.1 & 1.1 & 1.1 \\
\hline Net migration rate, $1995-994$. & -4.0 & 1.3 & .6 & -.6 & -2.9 & .1 & -1.2 \\
\hline Poverty rate, $2002 \ldots \ldots \ldots$. & 24.7 & 24.0 & 22.3 & 23.2 & 24.6 & 22.7 & 23.5 \\
\hline Unemployment rate, $2001 \ldots$. & 9.0 & 11.5 & 7.8 & 7.7 & 9.5 & 7.8 & 8.5 \\
\hline \multicolumn{8}{|l|}{ Population loss } \\
\hline \multicolumn{8}{|l|}{$\begin{array}{l}\text { Population loss } \\
\text { Tract (average characteristics) }\end{array}$} \\
\hline Number added ................ & 1,124 & 613 & 194 & 364 & 1,737 & 558 & 2,295 \\
\hline \multicolumn{8}{|l|}{ Share of families with income } \\
\hline Less than or equal to poverty level ................. & 9.3 & 7.1 & 14.1 & 11.1 & 8.5 & 12.1 & 9.4 \\
\hline 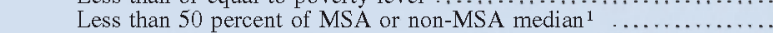 & 20.8 & 17.0 & 21.1 & 20.2 & 19.4 & 20.5 & 19.7 \\
\hline Between 50 percent and 80 percent of MSA or non-MSA median ${ }^{1}$. & 18.6 & 19.0 & 18.0 & 19.3 & 18.7 & 18.9 & 18.7 \\
\hline 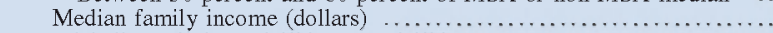 & 48,241 & 49,149 & 36,513 & 39,179 & 48,561 & 38,252 & 46,055 \\
\hline Median relative to MSA or non-MSA & 96.9 & 101.1 & 98.7 & 96.5 & 98.3 & 97.3 & 98.1 \\
\hline \multicolumn{8}{|l|}{ Housing } \\
\hline Median house value (dollars) & 135,845 & 106,363 & 55,698 & 59,298 & 125,444 & 58,046 & 109,067 \\
\hline Median house age (years)...$\ldots \ldots \ldots \ldots \ldots$. & 35.8 & 36.3 & 35.6 & 38.2 & 36.0 & 37.3 & 36.3 \\
\hline 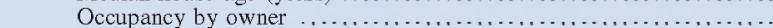 & 52.5 & 65.9 & 58.8 & 58.9 & 57.3 & 58.8 & 57.6 \\
\hline 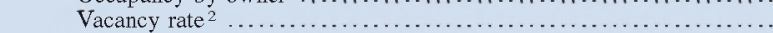 & 6.2 & 6.5 & 16.7 & 17.2 & 6.3 & 17.0 & 8.9 \\
\hline \multicolumn{8}{|l|}{ Population } \\
\hline Over age 65 & 14.5 & 14.0 & 14.3 & 16.4 & 14.3 & 15.7 & 14.6 \\
\hline & 44.6 & 30.3 & 28.1 & 17.6 & 39.5 & 21.2 & 35.1 \\
\hline \multicolumn{8}{|l|}{ County (average characteristics) } \\
\hline Population change, $1990-2000$ & 1.0 & 1.0 & 1.0 & .9 & 1.0 & 9 & 1.0 \\
\hline 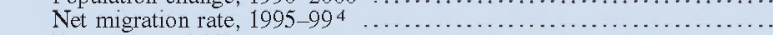 & -6.8 & -6.1 & -7.1 & -7.6 & -6.6 & -7.4 & -6.8 \\
\hline 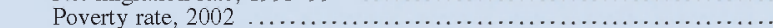 & 18.2 & 13.8 & 17.0 & 14.5 & 16.6 & 15.4 & 16.3 \\
\hline 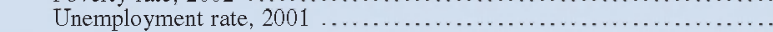 & 6.8 & 6.1 & 6.3 & 5.1 & 6.6 & 5.5 & 6.3 \\
\hline
\end{tabular}

NotE. Data exclude tracts in U.S.-affiliated areas and tracts without income information.

1. See table 14, note 1 .

2. Vacant housing units as a percentage of total housing units.

3. Non-whites or people of Hispanic origin.

tives for expanding the class of rural CRA-eligible tracts, the rural tracts that would be newly classified as CRA-eligible show more-favorable economic characteristics than do the rural tracts currently classified as such. The relationship of the newly classified rural CRA-eligible tracts to urban tracts currently classified as CRA-eligible is complicated. Under any of the alternatives, the newly added rural CRAeligible tracts would have lower poverty, unemployment, and population growth rates and higher owneroccupancy and vacancy rates than would the current urban CRA-eligible tracts; median incomes for both types of tract would be about the same. Moreover, the rural tracts that would be added under the alternatives that contribute the most rural tracts (100 percent
4. Difference between net migration in 1999 and net migration in 1995 as a percentage of the population in 1997.

5. See table 14 , note 2 .

6. For description of modification to CDFI Fund criteria, see text.

CDFI Fund Community Development Financial Institutions Fund.

of median family income and 80 percent of statewide median family income) show, not unexpectedly, the most-favorable economic characteristics.

When compared with the current rule (figure 3), each alternative adds a different set of newly CRAeligible rural tracts with significantly different geographic distributions. That is, with one exception, each alternative-raising the threshold from the current level to 90 percent (figure 4) or 100 percent (figure 5), changing the baseline to the statewide median income (figure 6), and adding the CDFI Fund's non-income criteria to the current 80 percent income rule (figure 7)-adds a set of tracts that differs from the other sets in terms of composition (the tracts that make it up), economic and 
3. Census tracts in rural counties: Share that is CRA-eligible under current rule, as of December 31, 2003

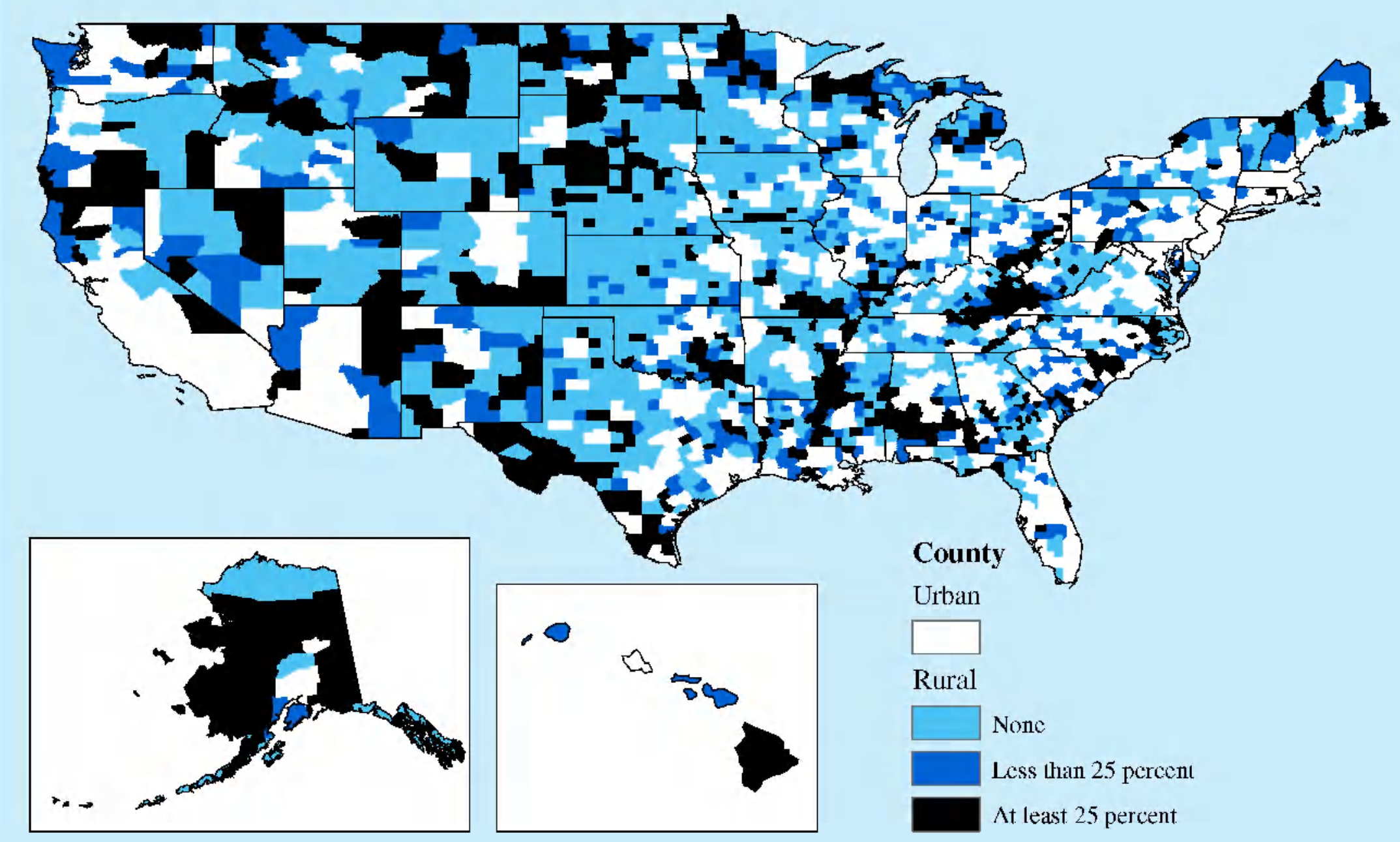

NOTE. Under the current rule, a rural census tract is CRA-eligible if the median family income in the tract is less than 80 percent of the median family income in the nonmetropolitan portion of the state. 


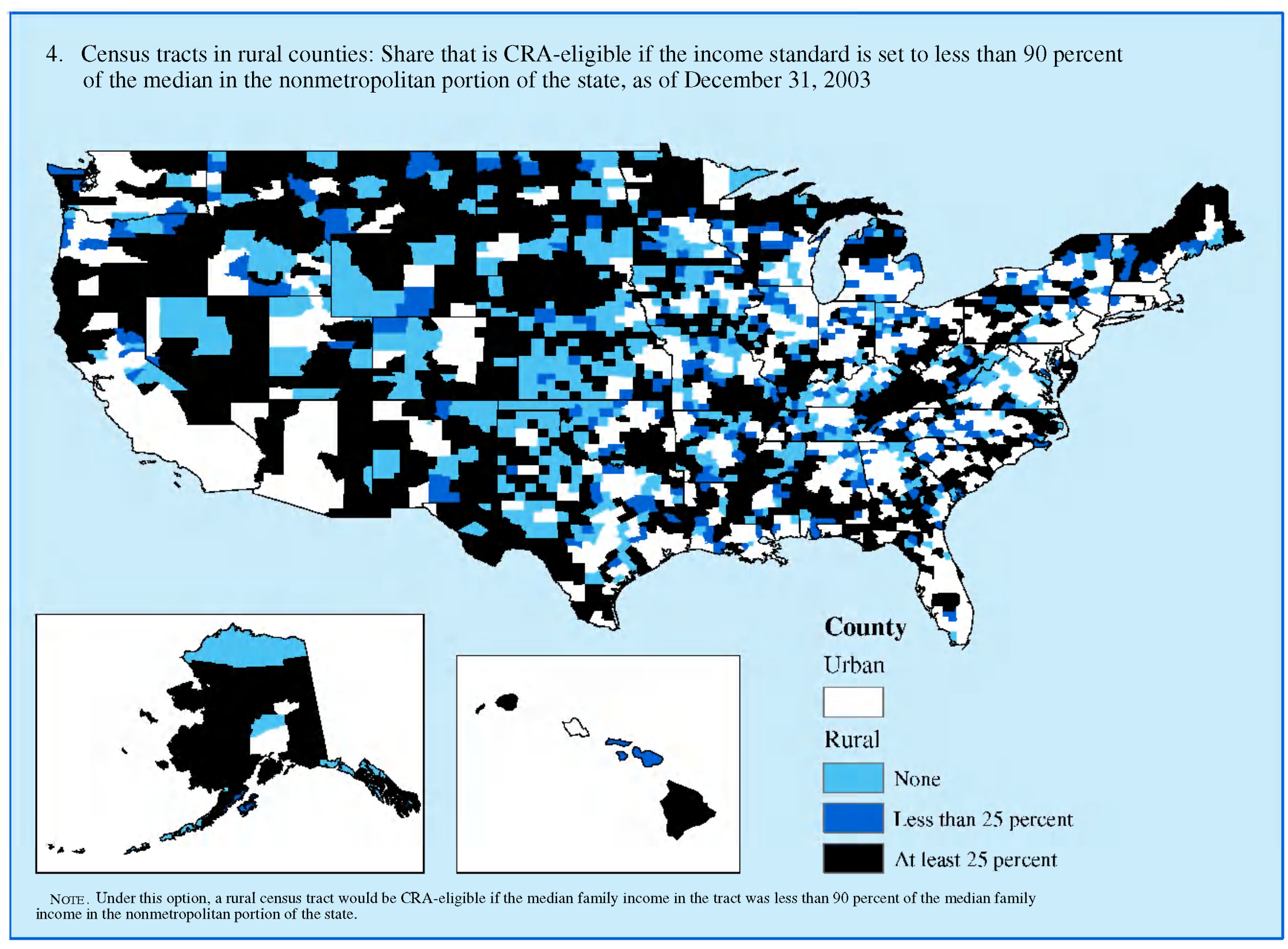


5. Census tracts in rural counties: Share that is CRA-eligible if the income standard is set to less than 100 percent of the median in the nonmetropolitan portion of the state, as of December 31, 2003

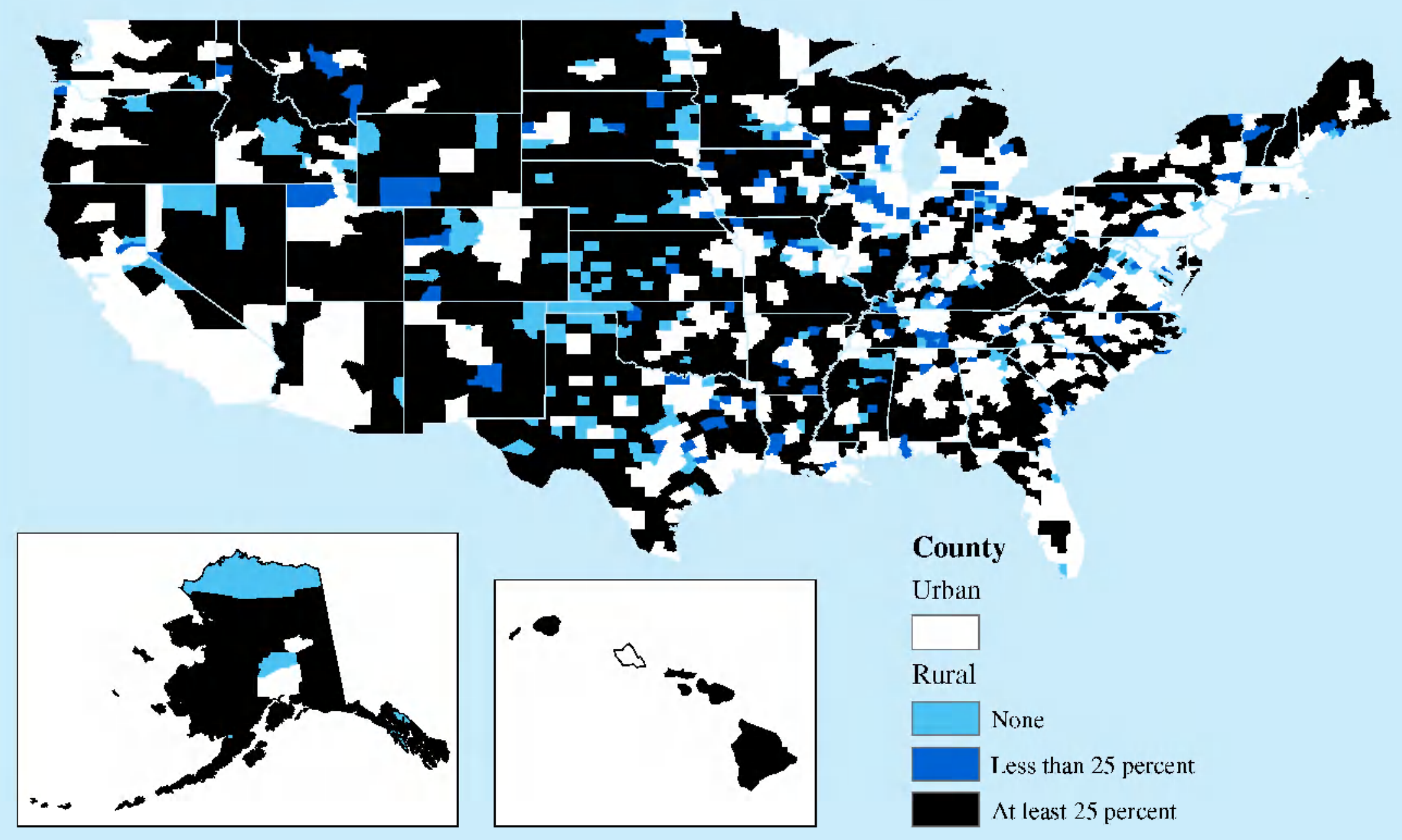

NOTE. Under this option, a rural census tract would be CRA-eligible if the median family income in the tract was less than 100 percent of the median family income in the nonmetropolitan portion of the state. 
6. Census tracts in rural counties: Share that is CRA-eligible if the current 80 percent income standard is broadened from the nonmetropolitan portion of the state to the entire state, as of December 31, 2003

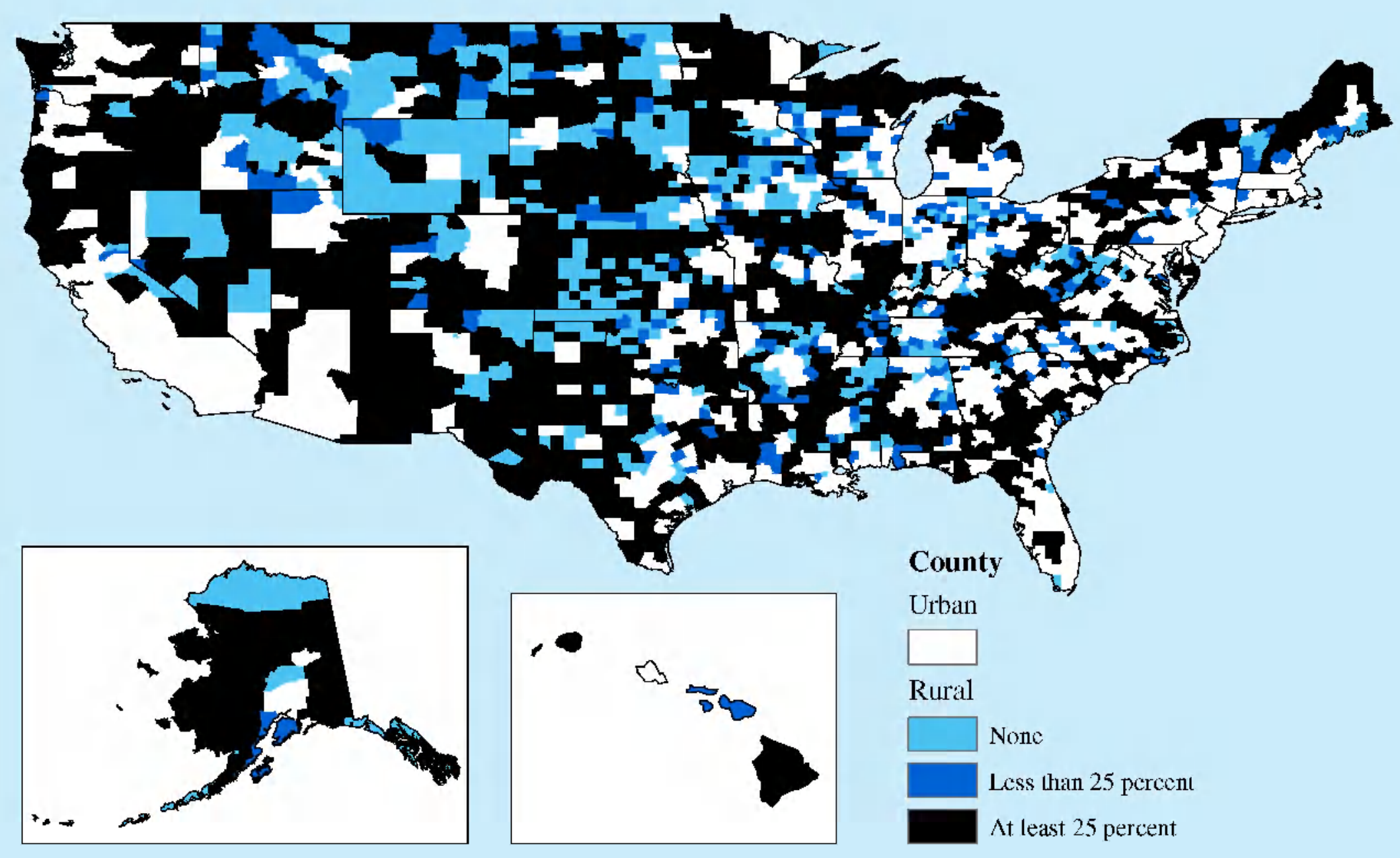

NOTE. Under this option, a rural census tract would be CRA-eligible if the median family income in the tract was less than 80 percent of the median family income in the entire state. 


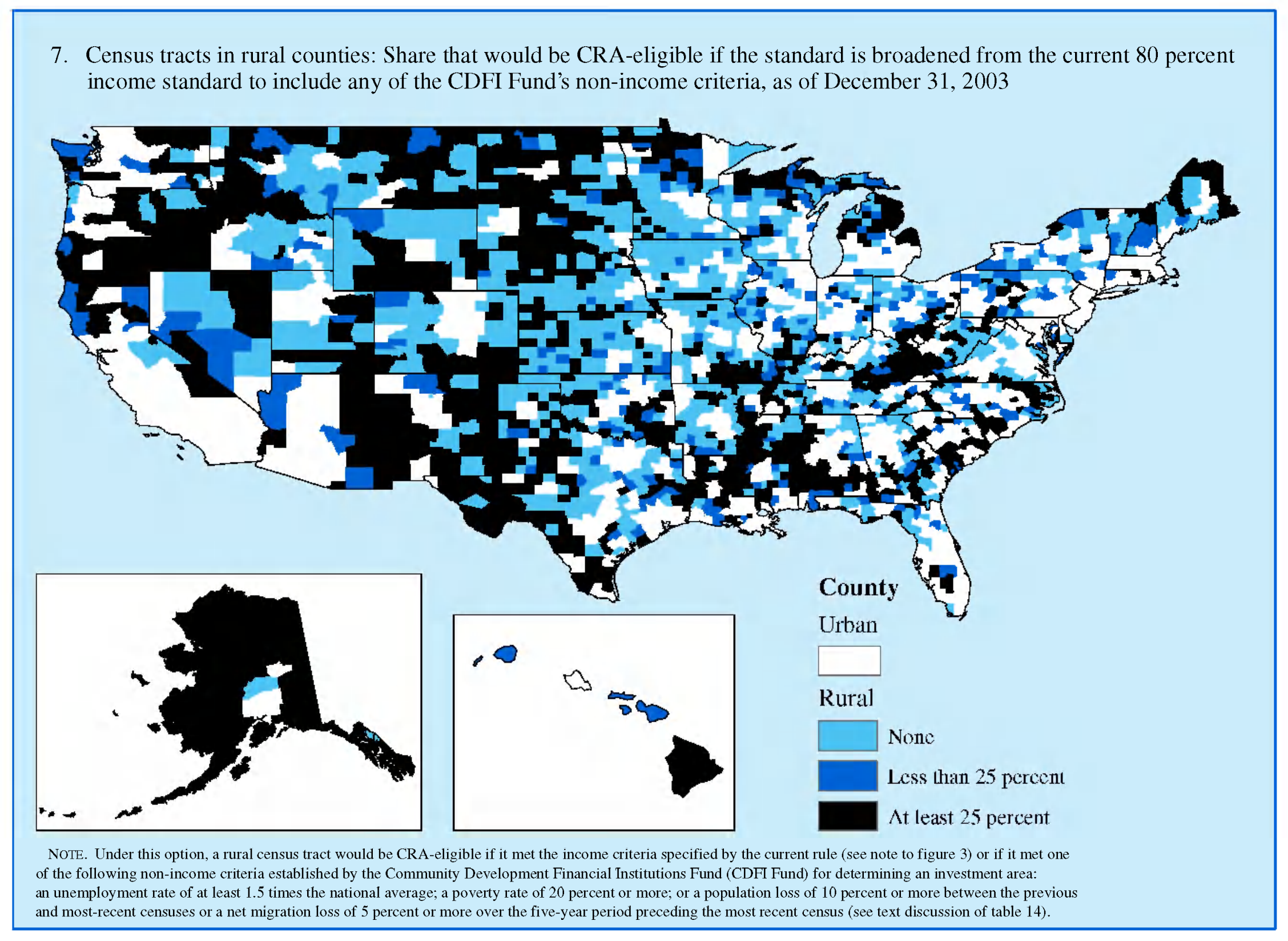


16. Number and share of rural banking institutions whose number of CRA-eligible census tracts in their assessment areas would increase under options for defining census tracts as CRA-eligible, as of December 31, 2003

\begin{tabular}{|c|c|c|c|c|c|c|c|}
\hline \multirow{3}{*}{ Item } & \multicolumn{3}{|c|}{ Income-lsaxed cplisms } & \multicolumn{4}{|c|}{ Vodified CDFi Г'und unituria } \\
\hline & \multicolumn{2}{|c|}{$\begin{array}{c}\text { Percent of nem-MSA } \\
\text { median }\end{array}$} & \multirow{2}{*}{$\begin{array}{l}\text { Less than } \\
80 \text { percent } \\
\text { of state } \\
\text { median }\end{array}$} & \multirow{2}{*}{ Combined } & \multicolumn{3}{|c|}{ Individual } \\
\hline & $\begin{array}{c}\text { Less than } \\
90\end{array}$ & $\begin{array}{c}\text { Less than } \\
100\end{array}$ & & & $\begin{array}{l}\text { Unem } \\
\text { ployment }\end{array}$ & Poverty & $\begin{array}{l}\text { Population } \\
\text { loss }\end{array}$ \\
\hline \multicolumn{8}{|l|}{ Large institutions } \\
\hline \multicolumn{8}{|l|}{ Currently with no CRA-eligible tracts } \\
\hline 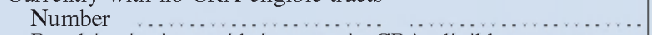 & 300 & 300 & 300 & 300 & 300 & 300 & 300 \\
\hline Rural institutions with increase in CRA-eligible tracts & & & & & & & \\
\hline 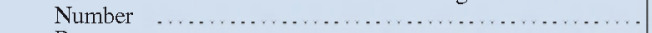 & 155 & 231 & 200 & 49 & 27 & 11 & 18 \\
\hline 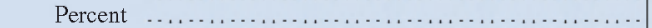 & 51.7 & 77.0 & 66.7 & 16.3 & 9.0 & 3.7 & 6.0 \\
\hline Average increase (percentage points) & 21.2 & 41.9 & 32.4 & 54.4 & 62.6 & 42.9 & 40.7 \\
\hline \multicolumn{8}{|l|}{ Currently with some CRA-eligible tracts } \\
\hline Number $\quad \ldots \ldots \ldots \ldots \ldots \ldots \ldots \ldots \ldots$ & 695 & 695 & 695 & 695 & 695 & 695 & 695 \\
\hline Rural institutions with increase in CRA-eligible tracts & & & & & & & \\
\hline 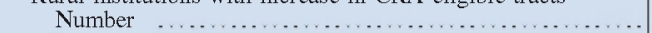 & 629 & 679 & 650 & 369 & 243 & 183 & 152 \\
\hline 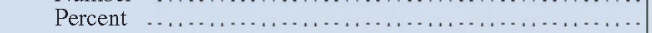 & 90.5 & 97.7 & 93.5 & 53.1 & 35.0 & 26.3 & 21.9 \\
\hline Average increase (percentage points) …............... & 16.4 & 37.2 & 27.0 & 27.5 & 23.7 & 20.0 & 14.8 \\
\hline \multicolumn{8}{|l|}{ Assessment areas currently with no CRA-eligible tracts } \\
\hline 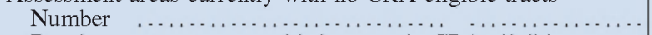 & 1,268 & 1,268 & 1,268 & 1,268 & 1,268 & 1,268 & 1,268 \\
\hline Rural assessment areas with increase in CRA-eligible tracts & & & & & & & \\
\hline 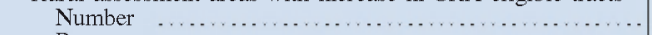 & 615 & 976 & 788 & 194 & 110 & 37 & 66 \\
\hline 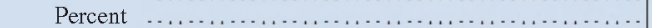 & 48.5 & 77.0 & 62.1 & 15.3 & 8.7 & 2.9 & 5.2 \\
\hline Average increase (percentage points) $\ldots \ldots \ldots \ldots \ldots \ldots \ldots \ldots . . . . .$. & 31.2 & 51.7 & 43.7 & 77.1 & 77.0 & 82.0 & 72.4 \\
\hline \multicolumn{8}{|l|}{ Assessment areas currently with some CRA-eligible tracts } \\
\hline 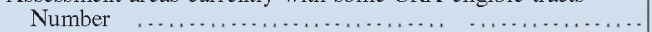 & 1,629 & 1,629 & 1,629 & 1,629 & 1,629 & 1,629 & 1,629 \\
\hline Rural assessment areas with increase in CRA-eligible tracts & & & & & & & \\
\hline 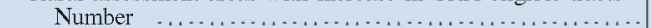 & 1,312 & 1.557 & 1,406 & 658 & 412 & 303 & 192 \\
\hline 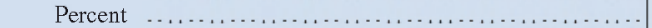 & 80.5 & 95.6 & 86.3 & 40.4 & 25.3 & 18.6 & 11.8 \\
\hline Average increase (percentage points) $\ldots \ldots \ldots \ldots \ldots \ldots \ldots . . . . .$. & 18.5 & 36.7 & 28.3 & 40.3 & 37.7 & 35.0 & 26.1 \\
\hline \multicolumn{8}{|l|}{ Small institutions ${ }^{1}$} \\
\hline \multicolumn{8}{|l|}{ Currently with no CRA-eligible tracts } \\
\hline 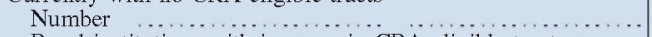 & 2,141 & 2,141 & 2,141 & 2,141 & 2,141 & 2,141 & 2,141 \\
\hline Rural institutions with increase in CRA-eligible tracts & & & & & & & \\
\hline 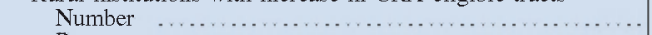 & 1,152 & 1,870 & 1,476 & 389 & 161 & 75 & 201 \\
\hline 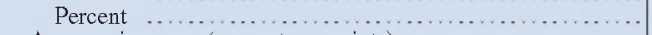 & 53.8 & 87.3 & 68.9 & 18.2 & 7.5 & 3.5 & 9.4 \\
\hline Average increase (percentage points) $\quad \ldots \ldots \ldots \ldots \ldots \ldots \ldots$ & 32.7 & 57.4 & 47.9 & 83.8 & 85.7 & 88.4 & 80.7 \\
\hline \multicolumn{8}{|l|}{ Currently with some CRA-eligible tracts } \\
\hline 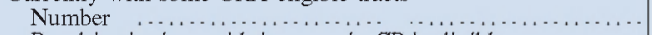 & 1,831 & 1,831 & 1,831 & 1,831 & 1,831 & 1,831 & 1,831 \\
\hline Rural institutions with increase in CRA-eligible tracts & & & & & & & \\
\hline 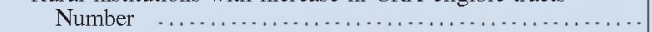 & 1,409 & 1,731 & 1,551 & 681 & 306 & 421 & 192 \\
\hline 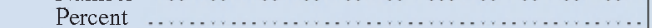 & 77.0 & 94.5 & 84.7 & 37.2 & 16.7 & 23.0 & $10 . \overline{5}$ \\
\hline Average increase (percentage points) $\quad \ldots \ldots \ldots \ldots \ldots \ldots \ldots$ & 23.2 & 41.4 & 34.1 & 47.6 & 42.8 & 45.6 & 40.0 \\
\hline
\end{tabular}

Note. See general note to table 9. A rural banking institution is an institution whose assessment area contains at least one rural census tract. For definition of relative tract income, see table 8 , note 1 . For description of CDFI Fund criteria, see text discussion of table 14. For definition of large and small institutions, see table 1 , note 1 . For description of assessment areas, see table 9 , note 1 .

1. Rural assessment areas were approximated by the rural counties in which small institutions had branches. These approximations were used to determine whether any of the census tracts served by small institutions would become CRA-eligible.

CDFI Fund Community Development Financial Institutions Fund.

demographic characteristics, and location. For example, of the 3,559 rural tracts added by adopting the modified CDFI Fund criteria or raising the threshold to 90 percent, only 760 (one-fifth) would be added by both options (data omitted from tables). Moreover, the modified CDFI Fund criteria themselves would add largely dissimilar sets of tracts: 18 percent of rural tracts that meet one or more of the criteria meet two or more of them, and less than 2 percent of rural tracts that meet one or more of the criteria meet all three criteria. ${ }^{35}$ The exception to the pattern is that

35. See David A. McGranahan and Calvin L. Beale (2002), "Understanding Rural Population Loss," Rural America, vol. 17 (Winter). The article is available on the website of the Economic Research Service, U.S. Department of Agriculture (www.ers.usda.gov). The substantial overlap exists between raising the threshold to 100 percent and using the statewide median income as the baseline. Of the 5,188 rural tracts that would be added by either alternative, 64 percent would be added by both options.

The alternatives can also be evaluated from the perspective of banking institutions. For example, 30 percent of large institutions with at least one branch in a rural area currently have no CRA-eligible tracts in any of their rural assessment areas (table 9). ${ }^{36}$ Under each of the three income-based

authors found that the rural areas with population loss are distinct from those with high poverty.

36. Assessment areas of small institutions are approximated by the counties in which they have branches. 
alternatives (raising the threshold to 90 percent or 100 percent or changing the baseline to the statewide median income), more than one-half of those institutions would have at least one $\mathrm{CR} \Lambda$-eligible tract in at least one of their rural assessment areas (table 16). In contrast, under the alternative of the modified CDFI Fund criteria, only 16 percent of those institutions now without any rural CRA-eligible tracts would have at least one; however, the 16 percent would on average have 54 percent of the rural tracts they serve classified as CRA-eligible. Although the incomebased measures affect many more institutions, the average effect on each institution is much smaller. For example, the typical institution that experienced a change under the statewide-median-income alternative would end up with 30 percent of its tracts classified as CRA-eligible. The difference arises from the operation of the modified CDFI Fund criteria at the county level: In our analysis, if a county meets a criterion, then all of its middle-income tracts become CRA-eligible. Each of the other, income-based alternatives is likely to affect only a portion of the middleincome tracts in a given county.

\section{SUMMARY OF FINDINGS}

The data and the analyses reported in this article may be useful in evaluating recent proposals to revise the CRA regulations. Because of data limitations, much of the analysis uses indirect rather than direct tests. From these tests, several findings emerge.

First, we found little evidence of differences in retail lending or branching between institutions just below and just above the $\$ 250$ million threshold that currently distinguishes institutions with small-institution evaluations from those with largeinstitution evaluations. Nor did we find evidence that institutions graduating from the small-institution evaluation to the large-institution evaluation significantly change their retail lending or branching behavior, at least in the first two years in which they are covered by the large-institution evaluation. However, the analysis was limited to inferences about the behavior of institutions around the margin of the current threshold, \$250 million. Although the evidence suggests that raising the threshold some amount above $\$ 250$ million would not have a significant effect on retail lending or branching, it fails to reveal what amount of increase in the threshold, if any, would result in a significant effect.

Second, in our investigation of the relationship of community development lending to overall CRA ratings for institutions examined under the largeinstitution examination, we found fairly consistent evidence that such lending plays a relatively limited role in determining overall CRA ratings. Indeed, a significant minority of institutions received "outstanding" ratings and reported no community development loans for three years; this finding holds true in each of several categories of institution asset size.

Third, we found little evidence to support the hypothesis that rural areas receive fewer retail loans or branches from CRA-covered institutions than do urban areas or that rural institutions have more difficulty in achieving "outstanding" ratings. Indeed, smaller rural institutions are equally or more likely to receive "outstanding" ratings than are smaller urban institutions. However, we found modest evidence that rural institutions are somewhat less likely to do any community development lending than are comparable urban institutions and that they make a lower volume of community development loans. These facts support the agencies' restriction of proposed revisions in the criteria for area-based CRA consideration to community development activities.

Finally, in our comparison of several proposals to expand area-based CRA consideration in rural areas, we found that all of the proposals would raise the number of CRA-eligible tracts in rural areas to the same percentage (or higher) as in urban areas. And all would add tracts with better economic characteristics than the tracts classified as lower-income under the 1995 regulations. However, each proposal adds a different set of tracts, affects a different number of banking institutions, and, in the case of institutions that are affected, affects them to different degrees. 